\title{
Pensions and Household Savings: Cross-Country Heterogeneity in Europe
}

\author{
Anna d'Addio ${ }^{1}$, Muriel Roger ${ }^{2}$ and Frédérique \\ Savignac $^{3}$
}

November 2019, WP \#738

\begin{abstract}
We address the question of whether the heterogeneity in savings is partly due to differences in pension wealth across individuals and across countries, using a European harmonised wealth survey (HFCS) combined with estimates of pension wealth (OECD). First, we find significant displacement effects of mandatory pension wealth on non-pension financial wealth at the mean, and a statistically significant crowd-out estimate on the probability of owning real estate property. Second, there is heterogeneity in the mean savings offset depending on age, risk attitudes and country. Third, the offset follows different patterns along the non-pension wealth distribution across countries. ${ }^{4}$

Keywords: Wealth, Pensions, Life Cycle

JEL classification: D31, D91, H55

\footnotetext{
1 GEM Report, UNESCO.

2 Paris I University

${ }^{3}$ Banque de France. Corresponding author: frederique.savignac@banque-france.fr

4 We would like to thank Rob Alessie, Olivier Allain, Michele Beloni, Vincent Bignon, Andrej Cupack, Rui Esteves, Bertrand Garbinti, Michael Haliassos, Tullio Jappelli, Ricky Kanabar, Arthur Kennickell, and Winfried Koeniger for their helpful discussions and suggestions as well as participants in the 2017 CeRP workshop on Household Finance and retirement savings, the 2017 AFSE meeting, the Eurosystem Household Finance and Consumption Research Workshop (March 2018), the $6^{\text {th }}$ Luxembourg workshop on Household Finance and Consumption, the 2018 SSES annual congress (St-Gallen), and the 2018 Deutsche Bundesbank International Conference on Household Finance. We also thank Thomas Blanchet for his very helpful input at the start of the project. A preliminary version circulated under the title "Private Wealth and Pensions across European Countries". Anna d'Addio was at OECD when working on this paper. This paper presents the authors' views and should not be interpreted as reflecting the views of the OECD, UNESCO, the Banque de France or Paris I University. The usual disclaimer applies.
}

Working Papers reflect the opinions of the authors and do not necessarily express the views of the Banque de France. This document is available on publications.banque-france.fr/en 


\section{NON-TECHNICAL SUMMARY}

How do pensions affect households' savings? Due to population ageing and the resulting pension reforms to make pension systems more sustainable implemented in many countries in recent years, income adequacy in old age is becoming a priority. There is however no consensus in the literature on the extent to which mandatory pensions offset private wealth. The empirical evidence on the offset of mandatory pensions by private wealth is mixed. Moreover, several authors suggest that a large heterogeneity in the pension-savings offset across individuals may exist depending on the composition of non-pension wealth, risk and time preferences, borrowing constraints, education, or financial literacy. To some extent, such differences can explain heterogeneity in wealth accumulation behaviours.

This paper addresses the question of whether heterogeneous saving behaviours are partly due to differences in pension wealth across individuals and countries (Figure A). To this end, we estimate the effect of mandatory pension wealth on private wealth at the individual level for seven euro area countries (Belgium, France, Germany, Greece, Italy, Luxembourg and Portugal). We consider a reduced-form equation of wealth accumulation based on the life-cycle framework with pensions. The identification strategy is based on the cross-country differences in pension schemes. One contribution of this paper is to provide countryspecific results, taking advantage of the non-linearity in pension schemes at the country level and of differences in pension enrolment across individuals within countries.

Figure A. Distributions of private wealth and mandatory pension wealth across countries $(1,000 €)$

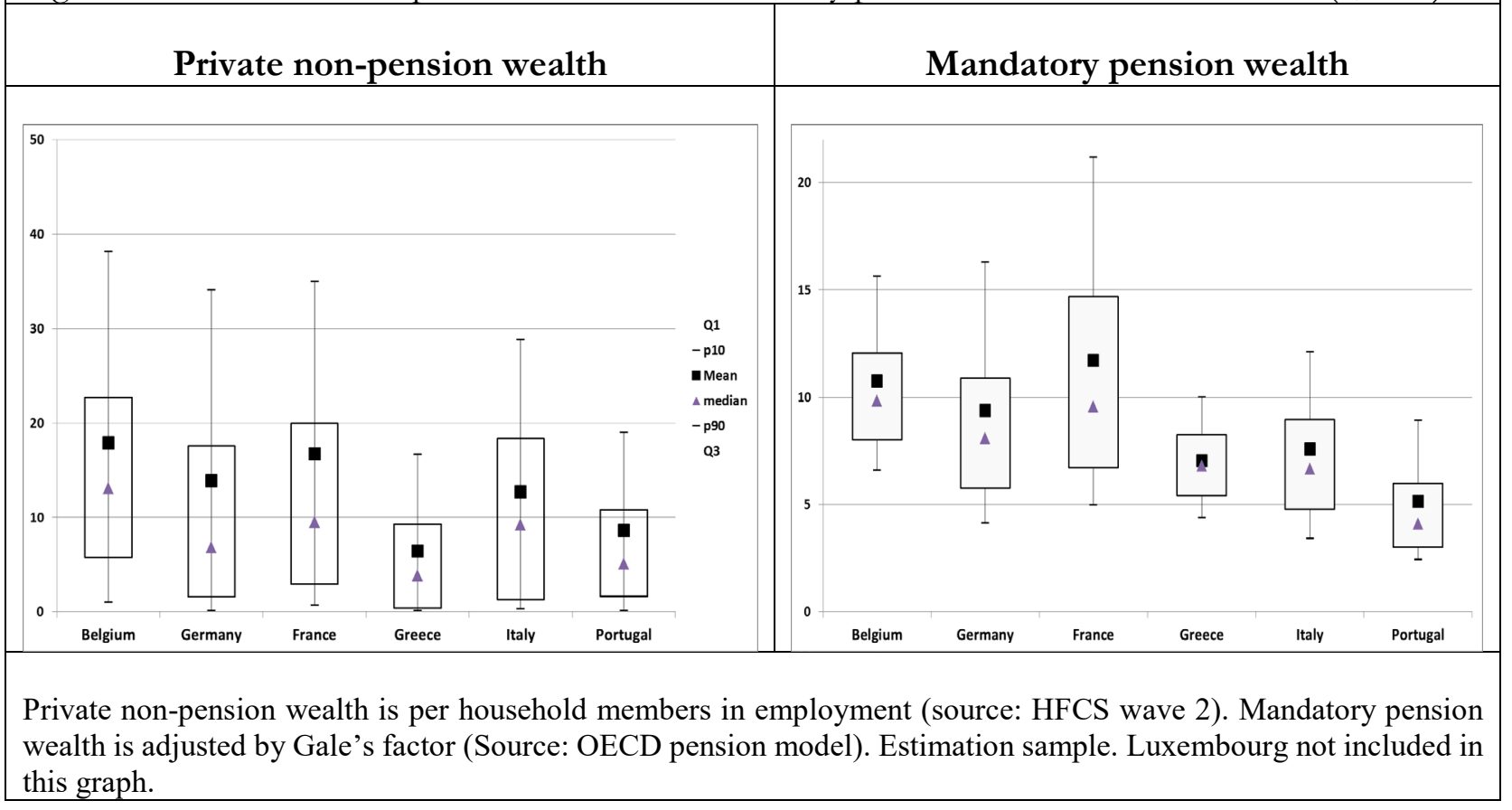

The empirical analysis is based on the Household Finance and Consumption Survey (HFCS, see Eurosystem Household Finance and Consumption Network, 2016a). The survey provides harmonised cross-country household-level information about net wealth, income and socio-demographics, along with some information on pension entitlement. This makes it possible to analyse the heterogeneity of the displacement effect for several European countries and for a various range of assets, based on several individual characteristics 
including risk preferences, and across the non-pension wealth distribution. The pension wealth indicator for mandatory pension schemes for private-sector workers is computed using the OECD pension models (OECD, 2015).

Our estimate suggests that one dollar of additional mandatory pension wealth reduces financial wealth by 53 cents at the mean, which is in line with the results from previous studies. A significant negative offset of pensions on the probability of holding real estate property at the mean is also found. Estimates reveal that the heterogeneity in the mean pension-savings offset varies across ages and depending on attitudes to risk. In particular, the magnitude of the offset is smaller for individuals who claim that they are "willing to take substantial financial risks" than for individuals "not willing to take any financial risk".

Overall, our results point to a large heterogeneity across European countries with respect to the pension-savings offset, which partly explains cross-country differences in saving behaviours. The pattern of the pension-savings offset along the non-pension wealth distribution varies from country to country. We find however evidence of complementarities between pensions and savings in the bottom deciles in most countries. This result may reflect the fact that less wealthy people tend to save more to finance consumption during old age due to increasing life expectancy and elderly care needs.

\title{
Retraite et épargne des ménages : hétérogénéité entre pays européens
}

\author{
RÉSUMÉ
}

Nous étudions le rôle du patrimoine «retraite» sur les comportements d'épargne des ménages de la zone euro. L'effet du patrimoine retraite sur le patrimoine hors retraite est estimé au niveau individuel à l'aide d'une enquête européenne harmonisée sur le patrimoine privé des ménages(HFCS) combinée à des estimations du patrimoine retraite (modèles de l'OCDE). Premièrement, nous trouvons des effets de substitution significatifs de la richesse retraite sur la richesse financière et sur la probabilité de posséder un bien immobilier. Deuxièmement, cet effet substitution moyen varie en fonction de l'âge, de l'attitude face au risque, et du pays. Troisièmement, l'effet du patrimoine retraite varie aussi d'un pays à l'autre selon le niveau de richesse privée des individus. Nous trouvons un effet de complémentarité entre patrimoine privé et patrimoine retraite pour les ménages les moins riches en Allemagne, en Grèce, en France et au Luxembourg.

Mots-clés : Patrimoine, Épargne, Retraite, Cycle de Vie

Les Documents de travail reflètent les idées personnelles de leurs auteurs et n'expriment pas nécessairement la position de la Banque de France. Ce document est disponible sur publications.banque-france.fr 


\section{Introduction}

How do pensions affect households' savings? This issue is highly relevant to policymakers facing population ageing and worrying about income adequacy in old age. During their lives, people contribute to pensions in most countries, be they mandatory or voluntary. There is however no consensus in the literature on the extent to which mandatory pensions offset private wealth. From a theoretical point of view, the effect of pensions on savings is ambiguous (Feldstein 1974; Blau 2016). In the life-cycle framework, pension benefits might diminish people's need to save during their working life to smooth consumption over their lives (negative offset). Yet a strong preference for leisure may push individuals both to retire earlier and to accumulate more private wealth to finance old-age needs (positive offset). Increases in life expectancy may also lead to higher savings rates (Bloom et al., 2003).

The empirical evidence on the offset of mandatory pensions by private wealth is mixed (e.g. Feldstein, 1974; Hubbard, 1986; Gale, 1998; Attanasio and Rohwedder, 2003; Attanasio and Brugiavini, 2003; Gale and Phillips, 2006; Engelhardt and Kumar, 2011; Alessie, et al., 2013). Several authors suggest that a large heterogeneity in the pension-savings offset across individuals may exist depending on the composition of non-pension wealth (Engelhardt and Kumar, 2011), risk and time preferences (Blau, 2016), borrowing constraints (Gale and Philips, 2006), education (Alessie, et al., 2013) or financial literacy (Lusardi and Mitchell, 2014; Americks et al., 2003). To some extent, such differences can explain heterogeneity in wealth accumulation behaviours.

This paper addresses the question of whether heterogeneous saving behaviours are partly due to differences in pension wealth across individuals and countries. To this end, we estimate the effect of mandatory pension wealth on private wealth at the individual level for seven euro area countries (Belgium, France, Germany, Greece, Italy, Luxembourg and Portugal). The distribution of household wealth as well as its composition vary greatly across these European countries (Piketty and Zucman, 2014; Arrondel et al., 2016; Eurosystem Household Finance and Consumption Network, 2016b). Many differences in the architecture of pension systems and design of public pension schemes exist across countries, even though they all have mandatory public pay-as-you-go pension systems. Within a single country, the design of pensions is also complex because benefits depend on the way they are related to earnings, career profiles, age, etc. (see OECD, 2015). 
We consider a reduced-form equation of wealth accumulation based on the life-cycle framework with pension (Gale, 1998; Hurd, et al., 2012; Alessie, et al., 2013; Engelhardt and Kumar, 2011). Our estimates are based on individual cross-section data relating to the year 2014. The identification strategy is based on the cross-country differences in pension schemes as in Alessie et al. (2013) and Hurd et al. (2012). One contribution of this paper is to provide country-specific results, taking advantage of the non-linearity in pension schemes at the country level and of differences in pension enrolment across individuals within countries. To our knowledge, this is the first paper that compares country-specific estimates based on a unified framework thanks to the data it uses. We adopt the instrumental variable approach from Engelhardt and Kumar (2011) to treat the endogeneity issue affecting pension wealth and savings. ${ }^{1}$

The empirical analysis is based on the Household Finance and Consumption Survey (HFCS, see Eurosystem Household Finance and Consumption Network, 2016a). The survey provides harmonised cross-country household-level information about net wealth, income and sociodemographics, along with some information on pension entitlement. This makes it possible to analyse the heterogeneity of the displacement effect for several European countries and for a various range of assets, based on several individual characteristics including risk preferences, and across the non-pension wealth distribution. ${ }^{2}$ We can also observe households when they take important decisions about savings and wealth accumulation throughout their entire working lives, whereas previous cross-country studies use surveys on health and retirement (such as SHARE, ELSA, HRS) focusing just on the elderly (over 50). The pension wealth indicator for mandatory pension schemes for private-sector workers is computed using the OECD pension models (OECD, 2015). The latter apply a single set of assumptions concerning the economic variables ${ }^{3}$ influencing pension wealth. The pension wealth resulting from this model thus reflects only cross-country differences and non-linearities in the design of mandatory pension schemes.

\footnotetext{
${ }^{1}$ Indeed, individual pension benefits depend on the wage profile and the length of working life, both of which may be affected by (unobserved) preferences for leisure. For example, if individuals have a high level of preference for leisure, it can simultaneously induce low wages and early retirement. These two elements affect pensions and savings simultaneously: lower wages lead to lower pensions; early retirement increases the need for wealth accumulation to finance the retirement period. In that case, we may overestimate the offset.

2 The HFCS wave 2 covers 20 European Union member states. We restrict our analysis to seven countries because some of the key variables are missing for the others (missing variables in the HFCS or pension indicators not computed by OECD), or because the sample size is too small.

${ }^{3}$ Economic growth, wage growth and inflation, see Appendix B.
} 
We define the pension wealth indicators by country and cohort for various wage levels and by gender and retirement age. The main characteristics we take into account to assign pension wealth to an individual in a given country are thus age, gender, income (as a percentage of the average income of the age group), the age at which he/she expects to retire, whether he/she has public pension plans and whether he/she has occupational pension plans. To build our instrumental variable, we get rid of differences in characteristics of recipients, which may be endogenous, and focus solely on the variations in benefits due to institutional differences between countries and groups of people. The instrumental variable is based on the countryspecific normal retirement age rather than on the individual's expectations about her/his retirement age. Identification within a country is then provided by differences in legislation between schemes and by differences in pension enrolment across individuals.

Our main results are as follows:

First, looking at the pooled sample of countries, we find a significant displacement effect of mandatory pension wealth on savings at the mean. Our IV estimate suggests that one dollar of additional mandatory pension wealth reduces financial wealth by 53 cents at the mean. This result is in line with previous studies using cross and within-country variations in pension wealth. Based on data from SHARE, ELSA and HRS for the year 2004, Hurd et al. (2012) find a displacement effect of 22 cents of financial assets for every additional dollar of public pension wealth. Alessie et al. (2013), using the third wave of SHARE (SHARELIFE) for the years $2008 / 2009$, find that each euro of pension wealth is associated with a 47 cent decline in non-pension wealth at the mean. Relative to these studies, we also investigate the displacement effect of pensions on housing wealth and find a statistically significant crowdout estimate of pension wealth on the probability of owning real estate property.

Second, we find new evidence of heterogeneity in the pension-savings offset. There is heterogeneity in the mean savings offset depending on age, risk attitudes and country. Our estimates show a larger negative pension-savings offset for people aged between 30 and 34 than for older people. The use of a cross-section prevents us from disentangling age effects from cohort effects. The magnitude of the offset is also lower for individuals claiming that they are "willing to take substantial or above average financial risks" than for individuals "not willing to take any financial risks". In particular, such differences in risk attitudes induce heterogeneous effects of pension wealth on risky financial assets, both regarding asset- 
holding decisions and the value of risky financial wealth. A substantial cross-country heterogeneity in the mean offset emerges from the estimates, which is not captured by age or risk attitudes.

Third, we analyse in depth the role of pension schemes in the cross-country heterogeneity of wealth accumulation behaviours. To this end, we estimate country-specific instrumental variable quantile regressions. Our results reveal cross-country heterogeneity in the pensionsavings offset. Such cross-country heterogeneity has not been investigated in previous papers. We find however evidence of a positive offset in the bottom deciles in Germany, Greece, France and Luxembourg. This result may reflect the fact that less wealthy people tend to save more to finance consumption during old age due to increasing life expectancy and elderly care needs.

Our estimates are based on wealth accumulation data and mandatory pension rules relating to the year 2014, which followed the sovereign debt crisis in the euro area, with many reforms, including to pensions, legislated for and implemented. The lack of confidence of individuals in the sustainability of the mandatory pension scheme is often put forward as a possible determinant of household savings, and may be a candidate to explain the cross-country heterogeneity. We are however unable to investigate such an assumption further with our data.

This paper is organised as follows. Section 2 describes the theoretical effects that can be expected from a pension scheme on private saving and presents previous empirical results. Section 3 is an overview of the mandatory pension schemes for the European countries under review. The empirical model is detailed in Section 4 and Section 5 describes our data. Our results are discussed in Section 6. Section 7 concludes. 


\section{Related literature}

The effect of pensions on savings is theoretically ambiguous (see Feldstein, 1974; Feldstein and Liebman, 2002). In a simple life-cycle model with rational savers, pension benefits, providing income during retirement, reduce their need to save during their working lives. Based on this, one might expect the pension-savings offset to vary across countries, with more generous pension systems inducing larger offsets. Withdrawal of pension benefits may also induce workers to retire earlier than they otherwise would have. It can also lead them to save more to finance retirement consumption, with an ensuing ambiguous net effect of pensions on saving. Moreover, longer life expectancy can result in higher saving rates at each age to finance consumption during old age (Bloom et al., 2003). In fact, with no social security system and with perfect capital market, the optimal length of working life increases to match the greater need to finance old-age consumption. Based on cross-country panel data, Bloom et al. (2003) show however that the rise in the retirement age is not enough to offset this increased need due to longevity, which may induce some complementarities between pension and savings. In countries with a mandatory retirement age or a strong incentive to retire at a target age, the positive effect on pre-retirement saving may be even stronger, reflecting greater accumulation of assets to finance longer retirement periods. Such a positive effect may also arise when pension benefits are expected to be low.

Deviations from the basic life-cycle model such as myopic agents, lack of trust in pension systems, borrowing constraints, uncertainty or bequest motives also lessen the pensionsavings offset. ${ }^{4}$ It is therefore difficult to predict the offset and how it may vary across countries.

Given these ambiguous theoretical predictions, the magnitude of the pension-savings offset becomes an empirical issue. Indeed, the empirical literature is large, but few articles provide international comparisons. Seminal papers have used aggregate time series, while more recently, following Gale (1998), they tend to draw on cross-sectional datasets. Some study the effect of specific pension reforms (Attanasio and Brugiavini, 2003, for Italy or Attanasio and Rohwedder, 2003, for the United Kingdom), while the majority use cross-sectional variations to estimate the pension-savings offset (Engelhardt and Kumar, 2011, Alessie et al., 2013,

\footnotetext{
${ }^{4}$ See for instance, Blau (2016). He shows that the simulated crowd-out may vary a lot depending on the type of assumptions in a life-cycle model.
} 
Hurd et al., 2012). The results point to a statistically and economically significant crowd-out: a decline of between about 20 cents and 60 cents in non-pension wealth for each dollar/euro of pension wealth. Moreover, Engelhardt and Kumar (2011), using US data, document that the magnitude of the offset increases along the wealth distribution from zero offsets below the median to 70 cents to dollar-for-dollar in the upper quantiles. To date, only two empirical studies have used both cross-country and within-country variations in pension benefits to estimate the pension-savings offset (Hurd et al., 2012; Alessie et al., 2013). Their samples are however too small to carry out country-specific analyses. Alessie et al. (2013) find differences between groups of countries, and especially a low negative offset in South and Eastern European countries before the sovereign debt crisis in Europe.

This paper aims to fill this gap by employing a harmonised empirical approach to estimate the pension-savings offset for several euro area countries. While all the countries covered in this study have mandatory public pay-as-you-go systems, many elements of heterogeneity in the design of mandatory pensions exist across countries, which are documented in the next section. Such heterogeneities in pension schemes may give rise to differences in saving behaviours across individuals and across countries, and thus cross-country variations in the pension-savings offset.

\section{Overview of mandatory pension schemes in Europe in 2014}

This section aims to document the main features of the structure of the mandatory part of the retirement-income provision for the year 2014 in the countries covered in the empirical analysis, i.e. Belgium, Germany, France, Greece, Italy, Luxembourg and Portugal (see Section 5). In all of them, the mandatory pension schemes are public pay-as-you-go systems. However, there is wide cross-country heterogeneity in the way public pensions are set up.

We follow the OECD's taxonomy (see OECD, 2015), which distinguishes two mandatory tiers fulfilling two distinct aims. The first mandatory tier, the adequacy part, includes public programmes designed to ensure pensioners achieve some absolute minimum standard of living (OECD, 2015, p. 124). This part of the retirement-income provision system helps to prevent poverty in old age and can include one or more redistributive components of three main types: basic pensions, minimum pensions and social assistance schemes. For example, 
Belgium, France, Germany, Italy, Luxembourg and Portugal all have redistributive components. Their characteristics are however country-specific (see Table B1.a and Table B1.b. in Appendix B). For example, in Belgium pensioners who have had earnings below a certain threshold ${ }^{5}$ or have been in part-time employment during their career are entitled to a minimum annual credit to increase their pension entitlements to that ceiling. In addition, there is a minimum earnings-related pension for those who have contributed for 45 years, and a safety-net income (the GRAPA) for those who have not accumulated any pension rights or for whom the latter are very low. France has both a non-means-tested minimum pension related to a person's contributory history (the "minimum contributif") and a means-tested minimum benefit (APSA). Greece and Italy no longer have non-means-tested minimum pensions following their most recent pension reforms. However, in both countries redistributive components exist. Greece has a basic pension scheme, while Italy had a means-tested taxexempt social assistance benefit from the age of 65 in 2013, a threshold which is increasing over time with life expectancy. Italy also has a minimum pension for those who started work before 1995. Germany, like Italy, has a redistributive social assistance component, while Luxembourg has three types of redistributive components in its mandatory public tier with an adequacy function, i.e. basic, minimum and social assistance schemes. The first two are subject to minimum contributory periods, while the latter requires that other conditions such as legal residence in the country are met. Finally, Portugal provides both a minimum pension and a means-tested targeted pension to fight poverty in old age.

The second part of the mandatory tier, the savings part, comprises earnings-related components designed to achieve some target standard of living in retirement compared with that when working, which can be public or private. Table B1.c in Appendix B summarises the main parameters by country for the year 2014 .

The part of the retirement-income provision fulfilling a savings function was of the defined benefit type in Belgium, Greece, Luxembourg and Portugal, with retirement income depending on the number of years of contribution and on individual earnings. For example, in Belgium the estimated annual accrual rate $^{6}$ is therefore $1.33 \%$ for a single pension. The earnings measure is lifetime pay and earlier years' earnings are revalued in line with prices. In Luxembourg, the yearly accrual rate is equal to $1.838 \%$. The earnings measure used in the formula to calculate the benefit is lifetime average pay revalued in line with nominal earnings

\footnotetext{
${ }^{5}$ This was $22,466.43$ euro in 2014.

${ }^{6}$ i.e. the rate at which benefit entitlements build up each year.
} 
growth. In Greece, the earnings-related pension accrual rate (from 1 January 2015) ranges between $0.80 \%$ per year up to $1.5 \%$ per year depending on the length of the insurance period. In Portugal, pension benefits are based on a reference earning. The accrual rate is $2 \%$ of the earnings base for each year of contributions for 20 or fewer years' contributions, with a lower limit of $30 \%$. As in Luxembourg, the accrual rate is higher for longer periods of contribution. Germany instead has a points system. In it, workers earn pension points based on their earnings each year. At retirement, the sum of pension points is multiplied by a pension-point value converted into a regular pension payment by multiplying the pension-point by a "pension-point value" factor" is used to factor in changes in the rate of contribution to the statutory pension scheme and to the subsidised (voluntary) private pension schemes: as contribution rates increase, the adjustment of the pension-point value declines. France has both a defined benefit and a point system. In the defined benefit scheme, the "régime general", the full pension is $50 \%$ of the earnings after a full career. For each missing quarter of contributions, however, the pension is reduced. The point system exists in the mandatory occupational public pension schemes where each year, the number of points earned is the value of contributions divided by the cost of a pension point. In Italy, the earnings-related mandatory part of the system is notional defined contributions. At retirement, the accumulated notional capital is converted into a stream of pension payments using a transformation coefficient (depending on life expectancy, the probability of leaving a surviving spouse behind and the expected duration of the survivor's benefit) on the accumulated life-long contributions valorised with the nominal GDP growth rate (as a five-year moving average).

There are also differences in the way past earnings are valorised to account for changes in living standards between the time pension rights accrued and the time they are claimed. Valorisation is based on prices in Belgium, France and Greece, on GDP growth in Portugal and Italy, and on average earnings in Luxembourg and Germany. Differences also exist in the indexation of pensions, i.e. the upward adjustment of pensions paid out, which is based on prices in Belgium, France and Italy, on a mix of prices and GDP growth in Greece and Portugal, and on average earnings in Germany. All of the countries included in the analysis, except Portugal, set a limit on the earnings used to calculate both contributions and pension benefits, introducing another element of cross-country heterogeneity regarding benefits. ${ }^{8}$

\footnotetext{
${ }^{7}$ This was 337.68 euro in 2014.

${ }^{8}$ France, for example, has different ceilings in the different components of the public pension system. The ceiling in the mandatory occupational scheme is higher than that set in the régime général.
} 
The elements of heterogeneity in the design of mandatory pension schemes across countries is used in this paper as a source of identification to estimate the pension-savings offset in the empirical models described in the next section.

\section{Empirical model}

\subsection{Baseline specification}

We follow Gale (1998) and Alessie et al. (2013) and derive the empirical equation from a simple life-cycle model (See Appendix A). We estimate a reduced-form equation of wealth accumulation, where non-pension wealth at a given age is a function of earnings and pension wealth. Pension wealth is adjusted by the Q factor, following Gale (1998). ${ }^{9}$ Our baseline empirical model is written as:

$$
\mathrm{W}_{\mathrm{i}, \mathrm{c}}=\beta_{0}+\beta_{1} \mathrm{Y}_{\mathrm{i}, \mathrm{c}}+\beta_{2} \mathrm{P}_{\mathrm{i}, \mathrm{c}}+\gamma \mathrm{X}_{\mathrm{i}, \mathrm{c}}+\delta_{c}+\mathrm{u}_{\mathrm{i}, \mathrm{c}}
$$

With $i$ denoting individuals, $c$ the country, $\mathrm{W}_{\mathrm{i}}$ non-pension wealth, $\mathrm{Y}_{\mathrm{i}}$ income, $\mathrm{P}_{\mathrm{i}}$ pension wealth (i.e the mandatory pensions for the private sector) adjusted by Gale's Q factor, while $\mathrm{X}_{\mathrm{i}}$ are additional controls to account for the life-cycle patterns, differences in preferences (i.e. risk aversion, time preferences, non-homothetic preferences), and wealth accumulation motives other than financing the retirement period (such as precautionary savings, bequest motives, etc.). $\delta_{c}$ is the country-specific effect for country $c$ and $\mathrm{u}_{\mathrm{i}}$ is the error term.

Equation (1) is estimated on the pooled sample of countries. In this case, the identification of the pension-savings offset $\left(\beta_{2}\right)$ is mostly provided by the cross-country differences in pension schemes described in the previous section.

Estimates may be biased if unobservable factors (such as preferences for leisure) affect both the determinants of pension wealth and savings. Our pension wealth variable depends on gender, year of birth, earnings and individuals' expectations about the age they expect to retire. To eliminate individual heterogeneity stemming from retirement expectations, we use

\footnotetext{
${ }^{9}$ See the background theoretical model in Appendix A and the definition of variables in Appendix B. Gale (1998) shows that simply regressing non-pension wealth against pension wealth (and controlling for earnings) leads to a downward bias in estimates because the wealth effects of pensions on the saving path is not taken into account. He provides an adjustment factor Q to correct for this bias.
} 
an instrumented pension wealth measure in the spirit of Engelhardt and Kumar (2011): rather than considering individuals' expectations about their retirement age, we assign each individual the country-specific normal retirement age.

We consider in turn several definitions of the dependent variable $\left(\mathrm{W}_{\mathrm{i}}\right)$ : total net non-pension wealth, financial assets, housing assets (taking account of both the probability of owning real estate property and housing wealth), risky financial assets (probability of holding risky financial assets and risky financial wealth). ${ }^{10}$

The pension offsets with total (non-pension) net wealth and with financial wealth are estimated with OLS and IV models. The crowd-out estimate of pension wealth on the probability of owning real estate property or risky financial assets are estimated using Probit and IV Probit models. Finally, we estimate the pension-housing wealth offset and the pensionrisky financial assets offset using Tobit and IV Tobit regressions. ${ }^{11}$

\subsection{Heterogeneous displacement effects}

\subsubsection{Heterogeneity in the mean pension-savings offset}

We investigate the heterogeneity in the mean pension-savings offset by adding interaction terms between pension wealth and individual characteristics in Equation (1). We then estimate the following regression:

$$
\mathrm{W}_{\mathrm{i}, \mathrm{c}}=\beta_{0}+\beta_{1} \mathrm{Y}_{\mathrm{i}, \mathrm{c}}+\beta_{2}^{\tilde{X}} \mathrm{P}_{\mathrm{i}, \mathrm{c}} * \tilde{X}_{i, \mathrm{c}}+\gamma \mathrm{X}_{\mathrm{i}, \mathrm{c}}+\delta_{c}+\mu_{\mathrm{i}, \mathrm{c}}
$$

where $\tilde{X}_{i}$ is a subset of the control variables $X_{i}$ in Equation (1). Interaction terms with pension wealth $P_{i}$ are used for the following (dummy) $\tilde{X}_{i}$ variables: age group, risk aversion, country and education of the reference person $i$, and whether he/she faces financial constraints. $Y_{\mathrm{i}}$ denotes income, $\mathrm{P}_{\mathrm{i}}$ pension wealth (mandatory pensions for the private sector) adjusted by Gale's Q factor, and $\delta_{c}$ is the country-specific effect for country $c . \mu_{\mathrm{i}}$ is the error term.

\footnotetext{
${ }^{10}$ See the detailed definition in Appendix B1.

${ }^{11}$ See Appendix B.2 for more detailed information on the estimation procedures.
} 
Similarly to Equation (1), Equation (2) is estimated on the pooled sample of countries and considering in turn net (non-pension) wealth and other assets as the dependent variable. Depending on the latter, we perform OLS and IV regressions (non-pension wealth, financial wealth), Probit or IV Probit (for the probability of owning real estate property and probability of holding risky financial assets) or Tobit and IV Tobit (for housing wealth and risky financial wealth).

\subsubsection{Heterogeneity across the non-pension wealth distribution}

Quantile regressions are used to investigate whether the pension-savings offset varies across the non-pension wealth distribution. Due to the large cross-country differences in the wealth distribution, we consider country-specific quantile regressions. At the country level, identification is then provided by the non-linearity in pension schemes and by the differences in pension enrolment across individuals.

Our quantile regression defined for a given country $c$ is written as:

$$
\mathrm{W}_{\mathrm{i}}=\beta_{0}^{\tau}+\beta_{1}^{\tau} \mathrm{Y}_{\mathrm{i}}+\beta_{2}^{\tau} \mathrm{P}_{\mathrm{i}}+\gamma^{\tau} \mathrm{X}_{\mathrm{i}}+\omega_{i}^{\tau}
$$

with $q_{\tau}\left(\omega^{\tau} \mid Y, P, X\right)=0, q_{\tau}$ being the conditional $\tau$-quantile.

As previously, $i$ denotes the individual index, $\mathrm{W}_{\mathrm{i}}$ is non-pension wealth, $\mathrm{Y}_{\mathrm{i}}$ income, $\mathrm{P}_{\mathrm{i}}$ pension wealth (mandatory pensions for the private sector) adjusted by Gale's $\mathrm{Q}$ factor, while $\mathrm{X}_{\mathrm{i}}$ are additional controls and $\omega_{i}^{\tau}$ is the error term. $\beta_{2}^{\tau}$ is then the pension-savings offset for the nonpension wealth quantile of order $\tau$. Instrumented quantile regressions are estimated with nonpension wealth or financial wealth as the dependent variable. ${ }^{12}$

\section{Data}

Our empirical analysis is based on individual-level information for seven euro area countries. We combine information about wealth, income and demographics extracted from the second wave of the Household Finance and Consumption Survey (Eurosystem Household Finance

\footnotetext{
${ }^{12}$ This uses the cqiv procedure in STATA provided by Chernozhukov et al. (2015).
} 
and Consumption Network, 2016b) with pension wealth simulations from the OECD pension models (OECD, 2015; 2013a). Our data relate to 2014.

\subsection{Sources and definitions}

\section{Non-pension wealth}

Information about wealth, income and socio-demographic variables are derived from the second wave of the Household Finance and Consumption Survey (HFCS), a cross-sectional survey covering 20 European countries. The survey methodology ensures countryrepresentativeness and cross-country comparability. ${ }^{13}$ This survey is thus a unique source for harmonised household-level information about wealth and income for euro area countries.

The main variables from HFCS we use are: household net wealth (real estate property, financial assets including voluntary pensions), income, demographic variables (household composition, age and education), expectations about retirement age, whether individuals report being eligible in the future for public and private pensions, whether they received any substantial gift or inheritance, and qualitative information about the willingness to take financial risks, credit constraints and future income expectations (See Appendix B1 for detailed definitions).

\section{Pension wealth}

Pension wealth is computed using the OECD Pension Model (see OECD, 2015)

Pension wealth is defined as the discounted sum of all future pension benefits taking into account residual life expectancy and the indexation of pension benefits in each country. The methodology and assumptions are harmonised, allowing direct cross-country comparisons of pension systems. Pension entitlements are computed on the basis of pension rules in 2014. ${ }^{14}$ The OECD pension models take account of the main characteristics of the country-specific mandatory pension schemes described in Section 3. The pension models provide pension wealth for the main national mandatory pension schemes for private-sector workers, as described in Section 2 (See Table B.1.a. and Table B.1.c. in Appendix B). Moreover, the model uses a single set of assumptions about economic variables that affect pension wealth

\footnotetext{
${ }^{13}$ See Eurosystem Household Finance and Consumption Network (2016a) for the methodological framework of the HFCS.

${ }^{14}$ Such an approach necessarily has some limitations: neither differentiated rules across generations due to ongoing reforms nor expectations regarding the credibility and sustainability of pension systems may be accounted for. We leave these issues for future research.
} 
(economic growth, wage growth and inflation, see Appendix B). In order to compute life expectancy, country-specific projections of the mortality rate by age and sex from the United Nations Population Database for the year of retirement are used. Pension wealth is computed in each country for men and women at various multiples of average earnings and retirement ages.

To assign pension wealth computed using the OECD pension model to the households surveyed in the HFCS, we use some individual characteristics also available in the HFCS. They are: gender, age, wage income (as a multiple of the average income for the age group), the age at which the individual expects to retire, and whether he/she has public or private pension plans.

\section{Instrumental variable}

We instrument the pension wealth variable to avoid any endogeneity bias arising from unobservable individual heterogeneity that may affect both pension wealth and savings behaviour. To build the instrument, we assign each individual the country-specific normal retirement age instead of considering the individual's expectations about the age at which he/she expects to retire (Figure 1).

\section{[INSERT FIGURE 1]}

Given the elements of variability other than retirement age which affect the instrumental variable (mainly income group, gender and non-linearities in pension schemes), the instrument varies both across groups of people within countries and across countries. The correlations between pension wealth (computed based on the individual expected retirement age) and the instrument (computed based on the country-specific normal retirement age) in each country are illustrated by the scatter plots in Figure 2.

\section{[INSERT: FIGURE 2]}

\subsection{Sample selection}

We carry out the empirical analysis on the data relating to seven European countries: Belgium, Germany, France, Greece, Italy, Luxembourg and Portugal. Other countries are 
excluded due to too small sample size, because some crucial information for our empirical analysis is missing (expected retirement age in the HFCS or in the OECD pension simulations for some countries) or because the reference year in the HFCS does not correspond to the available information for pension simulations.

We restrict our sample to individuals that are in employment and aged between 30 and 54 to avoid the presence of cross-country heterogeneity in terms of entry into the labour market or transition from employment to retirement. We also exclude self-employed people because their pension wealth is not estimated with the OECD pension models.

\subsection{Some descriptive statistics}

Our final sample includes 10,129 individuals with country-specific samples from 523 individuals for Belgium to 3,555 individuals for France (see Table B2 in Appendix B). Due to the rules we use to select the sample, individuals in our sample are wealthier, and are more often homeowners than the country-representative figures. ${ }^{15}$ Average non-pension wealth, illustrated in Figure 3, varies from 64,000 euro per adult in Greece to 433,000 euro per adult in Luxembourg. Figure 3 also illustrates the differences across countries and variations within countries in pension wealth: average adjusted pension wealth for the individuals in our sample varies between 51,500 euro in Portugal and 375,000 euro in Luxembourg. There is also variability in pension wealth within countries, due to the design of pension schemes. In Luxembourg, for example, we find a very large dispersion in pension wealth, while in Greece pension wealth is more equally distributed.

\section{[INSERT FIGURE 3]}

While the dataset only contains current earnings, many variables allow us to control for lifetime earnings (such as age and education of the reference person, household composition and income expectations). We also use information about credit constraints, gifts and inheritances received and a measure of risk aversion to control for other factors affecting wealth accumulation behaviours. Descriptive statistics for all these variables are available in Table B3 in Appendix B.

\footnotetext{
${ }^{15}$ See Eurosystem Household Finance and Consumption Network (2016b).
} 


\section{Results}

\section{1. Baseline results}

Table 1 shows the offset estimates obtained on the pooled sample of the seven countries (Equation 1). Each cell of the table represents an offset estimate based on a different regression model. We consider alternative dependent variables: total net (non-pension) wealth, financial wealth, housing assets (probability of owning real estate property and net housing wealth) and risky financial assets (probability of holding risky financial assets and value of risky financial assets). All specifications include country fixed effects and a set of controls for age, gender, education and income of the reference person, household composition (number of children, number of household members in employment), whether they have received any substantial gifts or inheritances, whether they have been credit constrained within the last three years, and future income expectations (see definitions in Appendix B1).

\section{[INSERT TABLE 1]}

For each dependent variable, we use two estimation methods: a non-instrumented one (ordinary least square, Probit or Tobit regressions depending on the dependent variable) and an instrumental variable approach (IV, IV Probit or IV Tobit). ${ }^{16}$

The results for the baseline specification, in which net (non-pension) wealth is the dependent variable, are shown in columns (1). The OLS estimate of the offset (-0.595) is negative and statistically significantly different from zero. It suggests that an additional euro of mandatory pension wealth reduces net wealth by 59.5 cents at the mean, everything else being equal. Accounting for the estimated standard errors, the 95\% confidence interval for the OLS estimate is between 34 cents and 85 cents at the mean. The IV estimate ( 22.7 cents) turns out to be non-statistically significant. When financial (non-pension) wealth is taken as the dependent variable (columns 2), both OLS and IV estimates are negative and statistically significant. Our IV estimate suggests that one additional euro of mandatory pension wealth reduces financial wealth by 53.1 cents at the mean (and between 30 cents and 76 cents considering the $95 \%$ confidence interval).

\footnotetext{
${ }^{16}$ We have checked that weak instrument issues are unlikely to be a concern: the F-statistics from the first stage are high due to the high correlation between pension wealth and the instrument variable (0.96). Detailed results with first stage estimates are available in Table $\mathrm{C} 1$ in Appendix C.
} 
Turning to real estate property (columns 3), we find a significant crowd-out estimate of pension wealth on the probability of owning real estate property using IV Probit: the probability of owning real estate property ${ }^{17}$ is 3 percentage points lower for an individual with 10,000 euro of additional pension wealth. The crowd-out estimate on housing wealth is however not statistically significant when the IV Tobit estimate is used.

The crowd-out estimates of pension wealth on risky financial assets are given in columns (4). We obtain statistically significant crowd-out estimates (both using Tobit and IV Tobit) of pension wealth on risky financial wealth. The magnitude of the offset is however limited (around 14 cents on average for people holding risky assets). The results concerning the probability of holding risky financial assets are less conclusive: the Probit estimate indicates that greater pension wealth has a positive effect on the probability of holding this type of financial asset, and this estimate turns out not to be statistically significant when IV Probit regression is used.

Overall, these results indicate a significant displacement effect of mandatory pension wealth on savings at the mean for the seven euro area countries in our sample. This displacement effect is statistically significant for financial wealth, and more specifically risky financial assets, as well as for the probability of owning real estate property.

Most of the control variables are statistically significant (see Table C2 in Appendix C). As expected, we obtain significant and increasing correlations between wealth and age in our sample restricted to individuals aged between 30 and 54 years old. This increasing pattern is observed with all net wealth components.

We also find positive estimates for income ${ }^{18}$ and education (which may be viewed as proxies for permanent income) on wealth accumulation. Household composition also matters, but its effect varies depending on the net wealth components. For instance, household size is positively associated with net wealth and housing wealth while the correlation between household size and risky financial assets (probability of holding risky financial wealth) is negative. ${ }^{19}$ The estimated coefficients of the number of children exhibit non-linear and decreasing pattern in most cases, except for risky financial assets where we find higher risky

\footnotetext{
${ }^{17}$ The percentage of individuals owning real estate property amounts to $73.5 \%$ in our sample.

${ }^{18}$ The only exception is financial wealth regressions, where the estimated effect of income turns out to be negative, which is unexpected.

${ }^{19}$ This negative correlation may reflect some background risks associated with having children which may lead individuals to limit their investment in risky financial assets.
} 
financial wealth for households with two children compared with the same household with no children. The estimated coefficient associated with the number of household members in employment is also negative in the net wealth, financial wealth, and housing wealth regressions, while the correlation with the probability of owning real estate property or risky financial assets is positive. Given these heterogeneous effects, one may conclude that the estimated coefficients in the total net wealth regression are likely to aggregate very heterogeneous behaviours depending on household net wealth composition.

Our data allow us to control for additional factors that are highly relevant in explaining saving behaviours. We find significant and negative coefficients for being credit constrained as well as a significant and positive coefficient of having received gifts or inheritances whatever the dependent variable. The estimated coefficients relating to risk aversion are statistically significant and suggest that individuals more willing to take financial risks are also the wealthier ones.

Finally, the country-specific effects are statistically significant and suggest cross-country heterogeneity in terms of saving behaviours.

\subsection{Heterogeneity in the pension-savings offset across ages, risk attitudes and countries}

Given these baseline results, one may wonder whether there is also heterogeneity in the displacement effect across age, education, risk attitudes and countries. In order to investigate this heterogeneity, we add to our baseline specification the interaction terms between pension wealth and some individual characteristics (age, willingness to take risks, the country the individual lives in $^{20}$ ) (Equation 2). We first consider the interactions between pension wealth and each characteristic in separate regressions (Table 2.a, Table 2.b, Table 2.c) and then introduce all three types of interaction at the same time into the regression (Table 2.d).

[INSERT TABLE 2. a]

[INSERT TABLE 2. b]

[INSERT TABLE 2. c]

\footnotetext{
${ }^{20}$ We have also tried interaction terms with education (See Table C3 in Appendix C) and interaction terms with the dummy variable reflecting the existence of financial constraints. They turn out not to be statistically significant.
} 


\section{[INSERT TABLE 2. d]}

\section{Heterogeneity across age groups}

The reference category consists of people aged between 30 and 34 years old. The crowd-out estimate suggests that for these individuals additional pension wealth is fully offset by net wealth (IV crowd-out estimate of -1.09), while the net wealth of people over 40 is less affected. There are non-linearities in the estimate across age groups. The magnitude of the offset decreases up to the 45-49 age group where there may even be some complementarities between pensions and savings: for this group, the additional effect of age on the offset estimate is about +1.40 on average, compared with the estimate obtained for the 30-34 age group (-1.09). For older people, the age-specific coefficient is lower $(+0.45)$ so that the offset is negative and levels off at 64.1 cents for one additional euro of pension wealth.

This pattern is confirmed when we look at the crowd-out estimates of pensions on detailed net wealth components by age group (Table 2.a, columns 2 to 4), as well as when we also consider additional interaction terms between pension wealth and risk aversion, and between pension wealth and country-specific effects (Table 2.d). These age-specific effects are thus not driven by the heterogeneity in risk aversion or by country-specific effects.

Given that we use a cross-section, we are not able to disentangle age effects from cohort effects. Our results are partly in line with the idea that people care more about their pension benefits when they are approaching retirement age.

\section{Heterogeneity according to the willingness to take financial risks}

We find lower offset estimates for categories which take more financial risks than the reference group "not willing to take any financial risk" (See Table 2.b). On average, the negative offset amounts to 77 cents for people not willing to take any financial risk while it is close to zero for people willing to take substantial financial risks when making investments (the specific coefficient for this category is 0.70 , so that the average offset for these people is negative and around 7 cents). This lower magnitude of the offset for people willing to take financial risks is also obtained with both financial and housing assets. 
These results are also robust when we add the additional interactions terms between pension wealth and age, and between pension wealth and country-specific effects (Table 2.d).

\section{Heterogeneity across countries}

We also find significant differences in the average offset of pensions on net wealth across the countries in our sample (Table 2.c). This cross-country heterogeneity is not captured by age or risk aversion factors (Table 2.d). We investigate this cross-country heterogeneity more specifically in the next sub-section, also taking into account the heterogeneous displacement effect across the non-pension wealth distribution.

\subsection{Country-specific results: heterogeneity across the wealth distribution}

Quantile regression is used to account for possible heterogeneity in the displacement effect across the wealth distribution (Equation 3). Due to the differences in the non-pension wealth distribution across countries, estimates are run on each country separately. We consider the quartiles in each country and provide the confidence interval (CI) at the 5\% level.

The results shed light on the heterogeneity in the pension-savings offset across countries. The pension-savings offset follows different patterns across the wealth distribution depending on the country.

\section{[INSERT TABLE 3a]}

\section{[INSERT TABLE 3b]}

However, only some estimated coefficients based on IV quartile regressions are statistically significant, due to large confidence intervals, especially at the top of the wealth distribution. These large confidence intervals may be explained by several reasons. First, heterogeneity in wealth is greater at the top of the distribution. Second, pension wealth is computed based on the main national mandatory pension schemes for private-sector workers. Because of the presence of ceilings in most of the pension schemes considered, high-income people may look for other forms of investment, in particular in private voluntary pensions, which in our analysis are considered to be financial assets (and thus included in the non-pension wealth dependent variable). 
We observe some common results: when significant, the estimated offset is positive for the first quartile (or the median), which indicates some complementarities between savings and pensions for low-wealth people (Table 3a). This result holds for net wealth and financial wealth in Germany, Greece, France and Luxembourg, and is in line with the prediction of Bloom et al. (2003). As life expectancy is increasing in European countries, people anticipate that they need to save more to finance consumption during old age. Such expectations might induce less wealthy people to accumulate more when they are able to do so. The increase in elderly care needs may also explain such complementarities between savings and pensions. While elderly care needs will increase in many countries in Europe, this issue may be crucial in countries like Germany, which is facing other major demographic changes that impact the provision of informal care to older adults by the family and other social network members. ${ }^{21}$ Indeed, due to a low birth rate and a large proportion of single households, ${ }^{22}$ it may be more difficult for a larger share of the German population to benefit from informal care. ${ }^{23}$ Other institutional features like low levels of replacement rate (less than 40\%, see OECD, 2015) and of homeownership (44\%) may also induce people to accumulate more financial assets when they are able to do so.

In France, we find significant effects of pension wealth on real estate property (Table 4): on average, the probability of owning real estate property ${ }^{24}$ is 3 percentage points lower for an individual with 10,000 euro of additional pension wealth. This result is line with the view of one's home as an insurance for old-age contingencies (Lusardi and Mitchell, 2007; Munnell et al., 2007), which may be particularly the case in countries where rents and housing prices are high like France.

\section{[INSERT TABLE 4]}

\section{Conclusion}

Due to population ageing and the resulting pension reforms to make pension systems more sustainable implemented in many countries in recent years, income adequacy in old age is becoming a priority. In fact, pensions are a crucial component of the portfolio held by older

\footnotetext{
${ }^{21}$ See Bonsang (2009) and Suanet et al. (2012) on informal care in European countries.

${ }^{22}$ About $40 \%$ of households according to the Household Finance and Consumption Survey.

${ }^{23}$ Long-term expenditure is projected to increase by $168 \%$ in Germany between 2000 and 2050 (Comas-Herrera et al. 2003).

${ }^{24}$ The percentage of individuals holding any real estate property amounts to $73.5 \%$ in our sample.
} 
people. Other components are accumulated over the life cycle, yet there is no consensus in the literature about the impact of pensions on savings.

This paper provides new evidence of heterogeneity in the pension-savings offset both across countries and across individuals. We estimate the pension-savings offset for seven European countries based on a wealth survey (the Household Finance and Consumption Survey, HFCS) and on the pension wealth simulations in the OECD pension models for 2014. We estimate a reduced-form equation for non-pension wealth accumulation over the life cycle (following Gale, 1998; Engelhardt and Kumar, 2011; and Alessie et al., 2013). Our identification strategy draws on the differences across countries and on the non-linearities within countries in the design of mandatory pension schemes. In the estimation strategy, we also adopt the instrumental variable approach proposed by Engelhardt and Kumar (2011), where the instrument variations only reflect variations in benefits due to institutional differences between countries and groups of people.

Our IV estimate suggests that one euro of additional mandatory pension wealth reduces financial wealth by 53 cents at the mean, which is in line with the results from previous studies. A significant negative offset of pensions on the probability of holding real estate property at the mean is also found. Estimates reveal that the heterogeneity in the mean pension-savings offset varies across ages and depending on attitudes to risk. In particular, the magnitude of the offset is smaller for individuals who claim that they are "willing to take substantial financial risks" than for individuals "not willing to take any financial risk".

Overall, our results point to a large heterogeneity across European countries with respect to the pension-savings offset, which partly explains cross-country differences in saving behaviours. The pattern of the pension-savings offset along the non-pension wealth distribution varies from country to country. We find however evidence of complementarities between pensions and savings in the bottom deciles in most countries.

Some of the country-specific results may be driven by individuals' lack of confidence in the sustainability of public pension schemes, which we are not able to account for in our empirical analysis. Another relevant topic for future research would be the differential impact of pension reforms (and thus of pension wealth) across cohorts and over the life cycle, in particular in countries where the implementation of pension reforms will take several decades. 


\section{REFERENCES}

Alessie R., Angelini V., van Santen P., 2013. Pension Wealth and Household Savings in Europe: Evidence from SHARELIFE. European Economic Review, 63, pp. 308-328.

Americks J., Caplin A., Leahy J., 2003. Wealth accumulation and the propensity to plan. Quarterly Journal of Economics, 118(3), pp. 1007-1048.

Arrondel L., Bartiloro L., Fessler P., Lindner P., Mathä T.Y., Rampazzi C., Schmidt T., Schürz M., Vermeulen P., 2016. How Do Households Allocate Their Assets? Stylized Facts from the Eurosystem Household Finance and Consumption Survey. International Journal of Central Banking, 12(2), pp.129-220.

Attanasio, O. P., Brugiavini, A., 2003. Social Security and Households Savings. Quarterly Journal of Economics, 118(3), pp. 1075-1119.

Attanasio O.P ., Rohwedder S., 2003. Pension Wealth and Household Saving: Evidence from Pension Reforms in the United Kingdom. American Economic Review, American Economic Association, vol. 93(5), pp. 1499-152.

Blau, D. M., 2016. Pensions, Household Saving, and Welfare: A Dynamic Analysis. Quantitative Economics, 7, pp.193-224.

Bloom D. E., Canning D., Graham B., 2003. Longevity and Life Cycle Savings, The Scandinavian Journal of Economics, vol 105(3), pp. 319-338.

Bonsang, E., 2009. Does informal care from children to their elderly parents substitute for formal care in Europe. Journal of Health Economics, 28, pp.143-154.

Bottazzi R., Jappelli T., Padula M., 2006. Retirement expectations, pension reforms, and their impact on private wealth accumulation. Journal of Public Economics, 90, pp. 2187-2212.

Campbell J., 2006. Household Finance, Journal of Finance, 61 (4), pp. 1553-1604.

Chernozhukov V, Fernandez-Val I., Kowalski A., 2015. Quantile Regression with Censoring and Endogeneity. Journal of Econometrics, 186, pp. 201-221.

Comas-Herrera, A., Costa-Font, J., Gori, C., di Maio, A., Patxot, C., Pickard, L., Pozzi, A., Rothgang, H., Wittenberg, R., 2003. European study of long-term care expenditure: investigating the sensitivity of projections of future long-term care expenditure in Germany, Spain, Italy and the United Kingdom to changes in assumptions about demography, dependency, informal care, formal care and unit costs. Report to the European Commission, Employment and Social Affairs DG. PSSRU Discussion Paper 1840.

Dohmen T., Falk A., Huffman D., Sunde U., Schupp J., Wagner G., 2011. Individual Risk Attitudes: Measurement, Determinants, and Behavioral Consequences. Journal of the European Economic Association, European Economic Association, vol. 9(3), pp. 522-550.

D’Orazio M., Di Zio M., and Scanu M., 2006. Statistical Matching, Theory and Practice. Wiley, New York. 
Eurosystem Household Finance and Consumption Network, 2016a, "The Eurosystem household finance and consumption survey: methodological report for the second wave", ECB Statistical Paper Series, No 17.

Eurosystem Household Finance and Consumption Network, 2016b, "The Eurosystem household finance and consumption survey: results from the second wave", ECB Statistical Paper Series, No 18.

Engelhardt, G. V., Kumar, A., 2011. Pensions and Household Wealth Accumulation. Journal of Human Resources, 46 (1), pp. 203-236.

Feldstein M., 1974. Social security, induced retirement and aggregate capital accumulation Journal of Political Economy, 82 (1974), pp. 905-926.

Feldstein M., Liebman J.B, 2002. Chapter 32 Social security, Handbook of Public Economics, Elsevier, Volume 4, pp. 2245-2324.

Gale, W. G., 1998. The Effects of Pensions on Household Wealth: A Reevaluation of Theory and Evidence. Journal of Political Economy, 106(4), pp.706-723.

Gale, W. G. \& Phillips, J. W. R., 2006. Pensions, Social Security Wealth and Lifetime Earnings: Evidence from the Health and Retirement Study. Center for Retirement Research at Boston College.

Hubbard, R. G., 1986. Pension Wealth and Individual Saving: Some New Evidence. Journal of Money, Credit and Banking, 18 (2). pp. 167-178.

Hubbard, R. G., 1987. Uncertain Lifetimes, Pensions, and Individual Saving. p. 175-210 in: Issues in Pension Economics. Zvi Bodie, John B. Shoven, and David A. Wise, eds. Chicago: Chicago University Press.

Hurd, M., Michaud, P.-C., Rohwedder, S., 2012. The Displacement Effect of Public Pensions on the Accumulation of Financial Assets. Fiscal studies, 33(1), pp. 107-128.

King, M. A., Dicks-Mireaux, L-D. L., 1982. Asset Holdings and the Life Cycle. Economic Journal, 92(366), pp. 247-67.

Lusardi, A. and Mitchell, O., 2007, Baby Boomer retirement security: The roles of planning, financial literacy, and housing wealth, Journal of Monetary Economics, vol. 54, No 1, pp. 205-224.

Lusardi A., Mitchell O.S, 2014. The economic importance of financial literacy: theory and evidence, Journal of Economic Literature, 52(1), pp. 5- 44.

Munnell, A., Soto, M. and Aubry, J. P., 2007. Do people plan to tap their home equity in retirement?, Center for Retirement Research, Boston College.

OECD, 2015. OECD Pensions at a Glance 2015, OECD Publishing Paris

Piketty T., Zucman G., 2014. Capital is Back: Wealth-Income Ratios in Rich Countries 17002010, The Quarterly Journal of Economics, Oxford University Press, vol. 129(3), pp. 12551310 . 
Rubin, D. B., 1996. Multiple Imputation After 18+ Years. Journal of the American Statistical Association, Vol. 91, No 434, June 1996, pp. 473-489.

Suanet, B., Van Groenou, M. B., Van Tilburg, T., 2012. Informal and formal home-care use among older adults in Europe: can cross-national differences be explained by societal context and composition?. Ageing and Society, 32, pp. 491-515. 


\section{Table 1. Baseline regressions: Estimates of the pension-savings offset}

\begin{tabular}{|c|c|c|c|c|c|c|c|c|c|c|c|c|}
\hline & \multicolumn{2}{|c|}{$\begin{array}{l}\text { Net wealth } \\
\text { (1) }\end{array}$} & \multicolumn{2}{|c|}{$\begin{array}{l}\text { Financial wealth } \\
\text { (2) }\end{array}$} & \multicolumn{4}{|c|}{$\begin{array}{l}\text { Housing wealth } \\
\text { (3) }\end{array}$} & \multicolumn{4}{|c|}{$\begin{array}{l}\text { Risky financial assets } \\
\text { (4) }\end{array}$} \\
\hline & $\begin{array}{c}\text { OLS } \\
\text { Coef. } \\
\text { (Std. Err.) }\end{array}$ & $\begin{array}{c}\text { IV } \\
\text { Coef. } \\
\text { (Std. Err.) }\end{array}$ & $\begin{array}{c}\text { OLS } \\
\text { Coef. } \\
\text { (Std. Err.) }\end{array}$ & $\begin{array}{c}\text { IV } \\
\text { Coef. } \\
\text { (Std. Err.) }\end{array}$ & $\begin{array}{c}\text { Probit } \\
\text { Marginal Ef. } \\
\text { (Std. Err.) }\end{array}$ & $\begin{array}{l}\text { IV Probit } \\
\text { Marginal Ef. } \\
\text { (Std. Err.) }\end{array}$ & $\begin{array}{c}\text { Tobit } \\
\text { Coef. } \\
\text { (Std. Err.) }\end{array}$ & $\begin{array}{c}\text { IV Tobit } \\
\text { Coef. } \\
\text { (Std. Err.) }\end{array}$ & $\begin{array}{c}\text { Probit } \\
\text { Marginal Ef. } \\
\text { (Std. Err.) }\end{array}$ & $\begin{array}{l}\text { IV Probit } \\
\text { Marginal Ef. } \\
\text { (Std. Err.) }\end{array}$ & $\begin{array}{c}\text { Tobit } \\
\text { Coef. } \\
\text { (Std. Err.) }\end{array}$ & $\begin{array}{l}\text { IV Tobit } \\
\text { Coef. } \\
\text { (Std. Err.) }\end{array}$ \\
\hline Pension wealth & $\begin{array}{c}-0.595^{\star \star \star} \\
(0.130)\end{array}$ & $\begin{array}{l}-0.227 \\
(0.154)\end{array}$ & $\begin{array}{c}-0.699^{* * *} \\
(0.097)\end{array}$ & $\begin{array}{c}-0.531^{* * *} \\
(0.115)\end{array}$ & $\begin{array}{l}-0.005 \\
(0.002)\end{array}$ & $\begin{array}{c}-0.031^{* * *} \\
(0.009)\end{array}$ & $\begin{array}{l}-0.123^{*} \\
(0.068)\end{array}$ & $\begin{array}{l}-0.009 \\
(0.081)\end{array}$ & $\begin{array}{l}0.003^{* *} \\
(0.001)\end{array}$ & $\begin{array}{c}0.008 \\
(0.006)\end{array}$ & $\begin{array}{c}-0.167^{\star * *} \\
(0.061)\end{array}$ & $\begin{array}{l}-0.142^{*} \\
(0.075)\end{array}$ \\
\hline Control variables & yes & yes & yes & yes & yes & yes & yes & yes & yes & yes & yes & yes \\
\hline Country fixed effects & yes & yes & yes & yes & yes & yes & yes & yes & yes & yes & yes & yes \\
\hline
\end{tabular}

Dependent variable: net wealth (columns 1, estimated by OLS and IV regressions), financial wealth (columns 2, estimated by OLS and IV regressions), housing wealth (columns 3 , probability of holding real estate property estimated by Probit and IV Probit and value of real estate property estimated by Tobit and IV Tobit), risky financial assets (columns 4 , probability of holding risky financial assets estimated by Probit and IV Probit, amount of risky financial assets estimated by Tobit and IV Tobit).

Control variables: age, gender, education and income of the reference person, household composition (number of children, number of household members in employment), having received any substantial gifts or inheritances, having been credit constrained within the last three years, future income expectations and willingness to take financial risks.

Countries: Belgium, Germany, France, Greece, Italy, Luxembourg and Portugal.

Estimated coefficients (and standard errors) for OLS, IV, Tobit, and IV Tobit regressions. Marginal effects (and standard errors) for Probit and IV Probit. Units for net wealth, financial wealth, housing wealth, risky financial assets, pension wealth and income: $10^{4}$ euro. Pension wealth is adjusted by Gale's $Q$ factor.

Significant at $* * * 1 \%, * * 5 \%$ and $* 10 \%$. Number of observations: 10,129 . 
Table 2.a. Estimates of the pension-savings offset: heterogeneity across age groups

\begin{tabular}{|c|c|c|c|c|c|c|c|c|c|c|c|c|}
\hline & \multicolumn{2}{|c|}{$\begin{array}{l}\text { Net wealth } \\
\text { (1) }\end{array}$} & \multicolumn{2}{|c|}{$\begin{array}{c}\text { Financial wealth } \\
\text { (2) }\end{array}$} & \multicolumn{4}{|c|}{$\begin{array}{c}\text { Housing wealth } \\
\text { (3) }\end{array}$} & \multicolumn{4}{|c|}{$\begin{array}{l}\text { Risky financial assets } \\
\text { (4) }\end{array}$} \\
\hline & $\begin{array}{c}\text { OLS } \\
\text { Coef. } \\
\text { (Std. Err.) }\end{array}$ & $\begin{array}{c}\text { IV } \\
\text { Coef. } \\
\text { (Std. Err.) } \\
\end{array}$ & $\begin{array}{c}\text { OLS } \\
\text { Coef. } \\
\text { (Std. Err.) } \\
\end{array}$ & $\begin{array}{c}\mathbf{I V} \\
\text { Coef. } \\
\text { (Std. Err.) } \\
\end{array}$ & $\begin{array}{c}\text { Probit } \\
\text { Marginal Ef. } \\
\text { (Std. Err.) }\end{array}$ & $\begin{array}{l}\text { IV Probit } \\
\text { Marginal Ef. } \\
\text { (Std. Err.) }\end{array}$ & $\begin{array}{c}\text { Tobit } \\
\text { Coef. } \\
\text { (Std. Err.) }\end{array}$ & $\begin{array}{c}\text { IV Tobit } \\
\text { Coef. } \\
\text { (Std. Err.) }\end{array}$ & $\begin{array}{c}\text { Probit } \\
\text { Marginal Ef. } \\
\text { (Std. Err.) }\end{array}$ & $\begin{array}{l}\text { IV Probit } \\
\text { Marginal Ef. } \\
\text { (Std. Err.) }\end{array}$ & $\begin{array}{c}\text { Tobit } \\
\text { Coef. } \\
\text { (Std. Err.) }\end{array}$ & $\begin{array}{c}\text { IV Tobit } \\
\text { Coef. } \\
\text { (Std. Err.) }\end{array}$ \\
\hline Pension wealth & $\begin{array}{c}-1.578^{\star * *} \\
-0.246\end{array}$ & $\begin{array}{c}-1.093^{* * *} \\
(0.274)\end{array}$ & $\begin{array}{c}-1.003^{* * *} \\
(0.183)\end{array}$ & $\begin{array}{c}-0.814^{* * *} \\
(0.204)\end{array}$ & $\begin{array}{l}-0,004 \\
(0.003)\end{array}$ & $\begin{array}{c}-0.030^{* *} \\
(0.013)\end{array}$ & $\begin{array}{c}-0.642^{* * *} \\
(0.128)\end{array}$ & $\begin{array}{c}-0.482^{* \star *} \\
(0.141)\end{array}$ & $\begin{array}{l}0.004^{*} \\
(0.002)\end{array}$ & $\begin{array}{c}0,006 \\
(0.010)\end{array}$ & $\begin{array}{c}-0.396^{\star * *} \\
(0.127)\end{array}$ & $\begin{array}{c}-0.424^{\star \star *} \\
(0.145)\end{array}$ \\
\hline Pension wealth* age[35 -39] & $\begin{array}{c}0.228 \\
(0.205)\end{array}$ & $\begin{array}{c}0.182 \\
(0.208)\end{array}$ & $\begin{array}{c}0.102 \\
(0.153)\end{array}$ & $\begin{array}{l}0.0903 \\
(0.155)\end{array}$ & $\begin{array}{l}-0.003 \\
(0.002)\end{array}$ & $\begin{array}{l}-0,005 \\
(0.008)\end{array}$ & $\begin{array}{l}0.0134 \\
(0.109)\end{array}$ & $\begin{array}{c}0.00965 \\
(0.111)\end{array}$ & $\begin{array}{l}-0,0003 \\
(0.002)\end{array}$ & $\begin{array}{c}0,002 \\
(0.008)\end{array}$ & $\begin{array}{l}0.0900 \\
(0.115)\end{array}$ & $\begin{array}{c}0.112 \\
(0.119)\end{array}$ \\
\hline Pension wealth* age[40 -44] & $\begin{array}{c}0.707^{* * *} \\
(0.195)\end{array}$ & $\begin{array}{c}0.589^{* \star *} \\
(0.199)\end{array}$ & $\begin{array}{l}0.278^{\star} \\
(0.145)\end{array}$ & $\begin{array}{c}0.240 \\
(0.148)\end{array}$ & $\begin{array}{l}-0,002 \\
(0.002)\end{array}$ & $\begin{array}{l}-0,004 \\
(0.008)\end{array}$ & $\begin{array}{c}0.313^{* \star *} \\
(0.103)\end{array}$ & $\begin{array}{l}0.266^{* *} \\
(0.105)\end{array}$ & $\begin{array}{c}0,002 \\
(0.002)\end{array}$ & $\begin{array}{c}0,010 \\
(0.007)\end{array}$ & $\begin{array}{l}0.276^{* *} \\
(0.108)\end{array}$ & $\begin{array}{c}0.304^{* * *} \\
(0.113)\end{array}$ \\
\hline Pension wealth* age[45 -49] & $\begin{array}{c}1.474^{* * *} \\
(0.192)\end{array}$ & $\begin{array}{c}1.404^{* \star *} \\
(0.197)\end{array}$ & $\begin{array}{c}0.710^{* * *} \\
(0.143)\end{array}$ & $\begin{array}{c}0.692^{* \star *} \\
(0.146)\end{array}$ & $\begin{array}{l}-0,0005 \\
(0.002)\end{array}$ & $\begin{array}{c}0,001 \\
(0.008)\end{array}$ & $\begin{array}{c}0.654^{* \star *} \\
(0.101)\end{array}$ & $\begin{array}{c}0.642^{* \star \star} \\
(0.103)\end{array}$ & $\begin{array}{l}-0,0002 \\
(0.002)\end{array}$ & $\begin{array}{c}0,003 \\
(0.007)\end{array}$ & $\begin{array}{c}0.307^{* * *} \\
(0.106)\end{array}$ & $\begin{array}{c}0.338^{* * *} \\
(0.111)\end{array}$ \\
\hline Pension wealth* age[50 -54] & $\begin{array}{c}0.566^{* \star *} \\
(0.193)\end{array}$ & $\begin{array}{l}0.452^{\star *} \\
(0.199)\end{array}$ & $\begin{array}{l}0.0347 \\
(0.143)\end{array}$ & $\begin{array}{l}0.00441 \\
(0.148)\end{array}$ & $\begin{array}{l}-0,0009 \\
(0.002)\end{array}$ & $\begin{array}{c}0,002 \\
(0.008)\end{array}$ & $\begin{array}{c}0.396^{* * *} \\
(0.101)\end{array}$ & $\begin{array}{c}0.364^{* \star *} \\
(0.104)\end{array}$ & $\begin{array}{l}-0,001 \\
(0.002)\end{array}$ & $\begin{array}{l}-0,003 \\
(0.007)\end{array}$ & $\begin{array}{c}0.146 \\
(0.107)\end{array}$ & $\begin{array}{c}0.174 \\
(0.112)\end{array}$ \\
\hline age[30 -34] & ref. & ref. & ref. & ref. & ref. & ref. & ref. & ref. & ref. & ref. & ref. & ref. \\
\hline age[35 -39] & $\begin{array}{c}0.906 \\
(2.218)\end{array}$ & $\begin{array}{c}0.943 \\
(2.231)\end{array}$ & $\begin{array}{c}0.666 \\
(1.649)\end{array}$ & $\begin{array}{c}0.635 \\
(1.659)\end{array}$ & $\begin{array}{c}0.088^{\star * \star} \\
(0.023)\end{array}$ & $\begin{array}{c}0.287^{\star \star *} \\
(0.084)\end{array}$ & $\begin{array}{c}3.297^{\star \star \star} \\
(1.247)\end{array}$ & $\begin{array}{l}3.203^{\star *} \\
(1.251)\end{array}$ & $\begin{array}{c}0,019 \\
(0.024)\end{array}$ & $\begin{array}{c}0,063 \\
(0.094)\end{array}$ & $\begin{array}{c}0.713 \\
(1.419)\end{array}$ & $\begin{array}{c}0.635 \\
(1.433)\end{array}$ \\
\hline age[40 -44] & $\begin{array}{c}0.420 \\
(2.110)\end{array}$ & $\begin{array}{c}0.881 \\
(2.125)\end{array}$ & $\begin{array}{c}0.290 \\
(1.569)\end{array}$ & $\begin{array}{c}0.407 \\
(1.580)\end{array}$ & $\begin{array}{c}0.112^{* * *} \\
(0.022)\end{array}$ & $\begin{array}{c}0.415^{* \star *} \\
(0.082)\end{array}$ & $\begin{array}{c}4.244^{* \star \star} \\
(1.182)\end{array}$ & $\begin{array}{c}4.448^{\star \star \star} \\
(1.186)\end{array}$ & $\begin{array}{c}0.034 \\
(0.023)\end{array}$ & $\begin{array}{c}0,123 \\
(0.089)\end{array}$ & $\begin{array}{c}0.205 \\
(1.333)\end{array}$ & $\begin{array}{l}0.0863 \\
(1.345)\end{array}$ \\
\hline age[45 -49] & $\begin{array}{l}-3.596^{*} \\
(2.104)\end{array}$ & $\begin{array}{l}-3.877^{*} \\
(2.121)\end{array}$ & $\begin{array}{l}-2.293 \\
(1.565)\end{array}$ & $\begin{array}{l}-2.482 \\
(1.577)\end{array}$ & $\begin{array}{c}0.129^{\star \star \star} \\
(0.023)\end{array}$ & $\begin{array}{c}0.476^{* \star *} \\
(0.082)\end{array}$ & $\begin{array}{c}3.297^{* \star *} \\
(1.168)\end{array}$ & $\begin{array}{c}3.100^{* \star *} \\
(1.171)\end{array}$ & $\begin{array}{c}0.076^{* \star *} \\
(0.023)\end{array}$ & $\begin{array}{c}0.277^{\star \star \star} \\
(0.088)\end{array}$ & $\begin{array}{c}1.119 \\
(1.305)\end{array}$ & $\begin{array}{c}0.952 \\
(1.318)\end{array}$ \\
\hline age[50 -54] & $\begin{array}{c}9.333^{* * *} \\
(2.140) \\
\end{array}$ & $\begin{array}{c}9.347^{\star \star *} \\
(2.158) \\
\end{array}$ & $\begin{array}{c}6.224^{\star \star *} \\
(1.592) \\
\end{array}$ & $\begin{array}{c}6.082^{* \star *} \\
(1.604) \\
\end{array}$ & $\begin{array}{c}0.171^{\star \star \star} \\
(0.023) \\
\end{array}$ & $\begin{array}{c}0.609^{* \star *} \\
(0.086) \\
\end{array}$ & $\begin{array}{c}8.666^{* \star \star} \\
(1.182) \\
\end{array}$ & $\begin{array}{c}8.611^{* \star *} \\
(1.186) \\
\end{array}$ & $\begin{array}{c}0.101^{\star \star \star} \\
(0.023) \\
\end{array}$ & $\begin{array}{c}0.388^{\star \star \star} \\
(0.088) \\
\end{array}$ & $\begin{array}{c}5.206^{\star \star \star} \\
(1.309) \\
\end{array}$ & $\begin{array}{c}5.064^{* \star *} \\
(1.323) \\
\end{array}$ \\
\hline $\begin{array}{l}\text { Other control variables } \\
\text { Country fixed effects }\end{array}$ & $\begin{array}{l}\text { yes } \\
\text { yes }\end{array}$ & $\begin{array}{l}\text { yes } \\
\text { yes }\end{array}$ & $\begin{array}{l}\text { yes } \\
\text { yes }\end{array}$ & $\begin{array}{l}\text { yes } \\
\text { yes }\end{array}$ & $\begin{array}{l}\text { yes } \\
\text { yes }\end{array}$ & $\begin{array}{l}\text { yes } \\
\text { yes }\end{array}$ & $\begin{array}{l}\text { yes } \\
\text { yes }\end{array}$ & $\begin{array}{l}\text { yes } \\
\text { yes }\end{array}$ & $\begin{array}{l}\text { yes } \\
\text { yes }\end{array}$ & $\begin{array}{l}\text { yes } \\
\text { yes }\end{array}$ & $\begin{array}{l}\text { yes } \\
\text { yes }\end{array}$ & $\begin{array}{l}\text { yes } \\
\text { yes }\end{array}$ \\
\hline
\end{tabular}

Dependent variable: net wealth (columns 1, estimated by OLS and IV regressions), financial wealth (columns 2, estimated by OLS and IV regressions), housing wealth (columns 3 , probability of owning real estate property estimated by Probit and IV Probit and value of real estate property estimated by Tobit and IV Tobit), risky financial assets (columns 4 , probability of holding risky financial assets estimated by Probit and IV Probit, amount of risky financial assets estimated by Tobit and IV Tobit).

Other control variables: gender, education and income of the reference person, household composition (number of children, number of household members in employment), having received any substantial gifts or inheritances, having been credit constrained within the last three years, future income expectations and willingness to take financial risks.

Countries: Belgium, Germany, France, Greece, Italy, Luxembourg and Portugal.

Estimated coefficients (and standard errors) for OLS, IV, Tobit, and IV Tobit regressions. Marginal effects (and standard errors) for Probit and IV Probit. Units for net wealth, financial wealth, housing wealth, risky financial assets, pension wealth and income: $10^{4}$ euro. Pension wealth is adjusted by Gale's $Q$ factor.

Significant at $* * * 1 \%, * * 5 \%$ and $* 10 \%$. Number of observations: 10,129 . 
Table 2.b. Estimates of the pension-savings offset: heterogeneity according to the willingness to take financial risks

\begin{tabular}{|c|c|c|c|c|c|c|c|c|c|c|c|c|}
\hline & \multicolumn{2}{|c|}{$\begin{array}{l}\text { Net wealth } \\
\text { (1) }\end{array}$} & \multicolumn{2}{|c|}{$\begin{array}{c}\text { Financial wealth } \\
\text { (2) }\end{array}$} & \multicolumn{4}{|c|}{$\begin{array}{c}\text { Housing wealth } \\
(3) \\
\end{array}$} & \multicolumn{4}{|c|}{$\begin{array}{c}\text { Risky financial assets } \\
\text { (4) }\end{array}$} \\
\hline & $\begin{array}{c}\text { OLS } \\
\text { Coef. } \\
\text { (Std. Err.) }\end{array}$ & $\begin{array}{c}\text { IV } \\
\text { Coef. } \\
\text { (Std. Err.) }\end{array}$ & $\begin{array}{c}\text { OLS } \\
\text { Coef. } \\
\text { (Std. Err.) }\end{array}$ & $\begin{array}{c}\text { IV } \\
\text { Coef. } \\
\text { (Std. Err.) }\end{array}$ & $\begin{array}{c}\text { Probit } \\
\text { Marginal Ef. } \\
\text { (Std. Err.) }\end{array}$ & $\begin{array}{c}\text { IV Probit } \\
\text { Marginal Ef. } \\
\text { (Std. Err.) }\end{array}$ & $\begin{array}{c}\text { Tobit } \\
\text { Coef. } \\
\text { (Std. Err.) }\end{array}$ & $\begin{array}{c}\text { IV Tobit } \\
\text { Coef. } \\
\text { (Std. Err.) }\end{array}$ & $\begin{array}{c}\text { Probit } \\
\text { Marginal Ef. } \\
\text { (Std. Err.) }\end{array}$ & $\begin{array}{c}\text { IV Probit } \\
\text { Marginal Ef. } \\
\text { (Std. Err.) }\end{array}$ & $\begin{array}{c}\text { Tobit } \\
\text { Coef. } \\
\text { (Std. Err.) }\end{array}$ & $\begin{array}{l}\text { IV Tobit } \\
\text { Coef. } \\
\text { (Std. Err.) }\end{array}$ \\
\hline Pension wealth & $\begin{array}{c}-1.074^{\star \star \star} \\
(0.144)\end{array}$ & $\begin{array}{c}-0.769^{\star \star \star} \\
(0.174)\end{array}$ & $\begin{array}{c}-1.077^{\star \star \star} \\
(0.107)\end{array}$ & $\begin{array}{c}-0.971^{\star \star \star} \\
(0.129)\end{array}$ & $\begin{array}{c}-0,004^{\star *} \\
(0.002)\end{array}$ & $\begin{array}{c}-0.026^{\star \star \star} \\
(0.009)\end{array}$ & $\begin{array}{c}-0.198^{\star \star \star} \\
(0.0744)\end{array}$ & $\begin{array}{c}-0.103 \\
(0.0897)\end{array}$ & $\begin{array}{c}0.002 \\
(0.001)\end{array}$ & $\begin{array}{l}0,0004 \\
(0.006)\end{array}$ & $\begin{array}{l}-0.326^{\star \star \star} \\
(0.0689)\end{array}$ & $\begin{array}{l}-0.382^{\star \star \star} \\
(0.0870)\end{array}$ \\
\hline Pension wealth* High or very high risk & $\begin{array}{c}0.721^{* \star \star} \\
(0.152)\end{array}$ & $\begin{array}{c}0.705^{\star \star \star} \\
(0.155)\end{array}$ & $\begin{array}{c}0.499^{\star \star \star} \\
(0.113)\end{array}$ & $\begin{array}{c}0.503^{\star \star \star} \\
(0.115)\end{array}$ & $\begin{array}{l}-0.003 \\
(0.002)\end{array}$ & $\begin{array}{l}-0,008 \\
(0.008)\end{array}$ & $\begin{array}{c}0.165^{\star \star} \\
(0.0781)\end{array}$ & $\begin{array}{l}0.171^{* *} \\
(0.0793)\end{array}$ & $\begin{array}{c}0.006^{\star \star \star *} \\
(0.002)\end{array}$ & $\begin{array}{c}0.022^{\star \star *} \\
(0.006)\end{array}$ & $\begin{array}{l}0.383^{\star * \star} \\
(0.0656)\end{array}$ & $\begin{array}{l}0.420^{* * *} \\
(0.0670)\end{array}$ \\
\hline Pension wealth Average risk & $\begin{array}{l}0.668^{\star \star \star} \\
(0.0907)\end{array}$ & $\begin{array}{l}0.648^{\star \star \star} \\
(0.0940)\end{array}$ & $\begin{array}{l}0.544^{\star \star *} \\
(0.0673)\end{array}$ & $\begin{array}{l}0.548^{\star \star \star} \\
(0.0697)\end{array}$ & $\begin{array}{c}-0.003^{* *} \\
(0.001)\end{array}$ & $\begin{array}{l}-0.007 \\
(0.005)\end{array}$ & $\begin{array}{l}0.0970^{\star *} \\
(0.0457)\end{array}$ & $\begin{array}{l}0.0930^{* *} \\
(0.0470)\end{array}$ & $\begin{array}{l}0.002^{\star *} \\
(0.001)\end{array}$ & $\begin{array}{l}0.009^{\star \star} \\
(0.003)\end{array}$ & $\begin{array}{l}0.154^{\star \star \star} \\
(0.0418)\end{array}$ & $\begin{array}{l}0.170^{\star \star \star} \\
(0.0436)\end{array}$ \\
\hline High or very high risk & $\begin{array}{c}1.885 \\
(2.765)\end{array}$ & $\begin{array}{c}2.025 \\
(2.786)\end{array}$ & $\begin{array}{l}-0.129 \\
(2.051)\end{array}$ & $\begin{array}{l}-0.188 \\
(2.066)\end{array}$ & $\begin{array}{c}0.046 \\
(0.032)\end{array}$ & $\begin{array}{c}0.139 \\
(0.117)\end{array}$ & $\begin{array}{l}2.678^{\star} \\
(1.487)\end{array}$ & $\begin{array}{l}2.578^{*} \\
(1.494)\end{array}$ & $\begin{array}{c}0.166^{\star \star \star \star} \\
(0.028)\end{array}$ & $\begin{array}{c}0.628^{\star \star \star} \\
(0.106)\end{array}$ & $\begin{array}{c}6.876^{\star \star \star} \\
(1.355)\end{array}$ & $\begin{array}{c}6.429^{\star \star \star} \\
(1.359)\end{array}$ \\
\hline Average risk & $\begin{array}{l}-2.327 \\
(1.473)\end{array}$ & $\begin{array}{l}-2.131 \\
(1.498)\end{array}$ & $\begin{array}{l}-2.775^{\star \star} \\
(1.093)\end{array}$ & $\begin{array}{c}-2.832^{\star \star} \\
(1.111)\end{array}$ & $\begin{array}{l}0.036^{*} \\
(0.017)\end{array}$ & $\begin{array}{l}0.105^{*} \\
(0.061)\end{array}$ & $\begin{array}{c}0.754 \\
(0.778)\end{array}$ & $\begin{array}{c}0.789 \\
(0.787)\end{array}$ & $\begin{array}{c}0.179^{\star \star \star \star} \\
(0.014)\end{array}$ & $\begin{array}{c}0.671^{\star \star \star} \\
(0.053)\end{array}$ & $\begin{array}{c}6.410^{\star \star \star} \\
(0.754)\end{array}$ & $\begin{array}{c}6.195^{\star \star \star} \\
(0.766)\end{array}$ \\
\hline No risk & ref. & $\begin{array}{c}\text { ref. } \\
-\end{array}$ & ref. & ref. & ref. & ref. & ref. & $\begin{array}{c}\text { ref. } \\
-\end{array}$ & $\begin{array}{c}\text { ref. } \\
-\end{array}$ & $\begin{array}{c}\text { ref. } \\
-\end{array}$ & $\begin{array}{c}\text { ref. } \\
-\end{array}$ & ref. \\
\hline $\begin{array}{l}\text { Other control variables } \\
\text { Country fixed effects }\end{array}$ & $\begin{array}{l}\text { yes } \\
\text { yes }\end{array}$ & $\begin{array}{l}\text { yes } \\
\text { yes }\end{array}$ & $\begin{array}{l}\text { yes } \\
\text { yes }\end{array}$ & $\begin{array}{l}\text { yes } \\
\text { yes }\end{array}$ & $\begin{array}{l}\text { yes } \\
\text { yes }\end{array}$ & $\begin{array}{l}\text { yes } \\
\text { yes }\end{array}$ & $\begin{array}{l}\text { yes } \\
\text { yes }\end{array}$ & $\begin{array}{l}\text { yes } \\
\text { yes }\end{array}$ & $\begin{array}{l}\text { yes } \\
\text { yes }\end{array}$ & $\begin{array}{l}\text { yes } \\
\text { yes }\end{array}$ & $\begin{array}{l}\text { yes } \\
\text { yes }\end{array}$ & $\begin{array}{l}\text { yes } \\
\text { yes }\end{array}$ \\
\hline
\end{tabular}

Dependent variable: net wealth (columns 1, estimated by OLS and IV regressions), financial wealth (columns 2, estimated by OLS and IV regressions), housing wealth (columns 3, probability of owning real estate property estimated by Probit and IV Probit and value of real estate property estimated by Tobit and IV Tobit), risky financial assets (columns 4 , probability of holding risky financial assets estimated by Probit and IV Probit, amount of risky financial assets estimated by Tobit and IV Tobit).

Other control variables: age, gender, education and income of the reference person, household composition (number of children, number of household members in employment), having received any substantial gifts or inheritances, having been credit constrained within the last three years, future income expectations. "Average risk" is a dummy variable equal to one when the individual answers that they are willing to take average financial risks expecting to earn average returns, "High or very high risk" is a dummy variable equal to one when the individual answers that they are willing to take above average or substantial financial risks expecting to earn above average or substantial returns.

Countries: Belgium, Germany, France, Greece, Italy, Luxembourg's and Portugal.

Estimated coefficients (and standard errors) for OLS, IV, Tobit, and IV Tobit regressions. Marginal effects (and standard errors) for Probit and IV Probit. Units for net wealth, financial wealth, housing wealth, risky financial assets, pension wealth and income: $10^{4}$ euro. Pension wealth is adjusted by Gale's $Q$ factor.

Significant at $* * * 1 \%, * * 5 \%$ and $* 10 \%$. Number of observations: 10,129 . 
Table 2c. Estimates of the pension-savings offset: heterogeneity across countries

\begin{tabular}{|c|c|c|c|c|c|c|c|c|c|c|c|c|}
\hline & \multicolumn{2}{|c|}{$\begin{array}{l}\text { Net wealth } \\
\text { (1) }\end{array}$} & \multicolumn{2}{|c|}{$\begin{array}{c}\text { Financial wealth } \\
(2)\end{array}$} & \multicolumn{4}{|c|}{$\begin{array}{l}\text { Housing wealth } \\
\text { (3) }\end{array}$} & \multicolumn{4}{|c|}{$\begin{array}{l}\text { Risky financial assets } \\
\text { (4) }\end{array}$} \\
\hline & $\begin{array}{c}\text { OLS } \\
\text { Coef. } \\
\text { (Std. Err.) }\end{array}$ & $\begin{array}{c}\text { IV } \\
\text { Coef. } \\
\text { (Std. Err.) }\end{array}$ & $\begin{array}{c}\text { OLS } \\
\text { Coef. } \\
\text { (Std. Err.) }\end{array}$ & $\begin{array}{c}\text { IV } \\
\text { Coef. } \\
\text { (Std. Err.) }\end{array}$ & $\begin{array}{c}\text { Probit } \\
\text { Marginal Ef. } \\
\text { (Std. Err.) }\end{array}$ & $\begin{array}{l}\text { IV Probit } \\
\text { Marginal Ef. } \\
\text { (Std. Err.) }\end{array}$ & $\begin{array}{c}\text { Tobit } \\
\text { Coef. } \\
\text { (Std. Err.) }\end{array}$ & $\begin{array}{l}\text { IV Tobit } \\
\text { Coef. } \\
\text { (Std. Err.) }\end{array}$ & $\begin{array}{c}\text { Probit } \\
\text { Marginal Ef. } \\
\text { (Std. Err.) }\end{array}$ & $\begin{array}{l}\text { IV Probit } \\
\text { Marginal Ef. } \\
\text { (Std. Err.) }\end{array}$ & $\begin{array}{c}\text { Tobit } \\
\text { Coef. } \\
\text { (Std. Err.) }\end{array}$ & $\begin{array}{l}\text { IV Tobit } \\
\text { Coef. } \\
\text { (Std. Err.) }\end{array}$ \\
\hline Pension wealth & $\begin{array}{l}-0.881^{* * *} \\
(0.137)\end{array}$ & $\begin{array}{c}-1.022^{* * *} \\
(0.219)\end{array}$ & $\begin{array}{c}-0.908^{* * *} \\
(0.101)\end{array}$ & $\begin{array}{c}-1.228^{* * *} \\
(0.162)\end{array}$ & $\begin{array}{c}-0.008^{\star \star *} \\
(0.002)\end{array}$ & $\begin{array}{c}-0.041^{\star * *} \\
(0.010)\end{array}$ & $\begin{array}{l}-0.191^{* * *} \\
(0.0711)\end{array}$ & $\begin{array}{l}-0.184^{*} \\
(0.0992)\end{array}$ & $\begin{array}{l}0.002^{*} \\
(0.001)\end{array}$ & $\begin{array}{c}0.004 \\
(0.007)\end{array}$ & $\begin{array}{l}-0.274^{* * *} \\
(0.0634)\end{array}$ & $\begin{array}{l}-0.516^{\star \star *} \\
(0.0907)\end{array}$ \\
\hline Pension wealth*Belgium & $\begin{array}{l}-0.999^{\star *} \\
(0.462)\end{array}$ & $\begin{array}{c}-1.889^{\star * *} \\
(0.532)\end{array}$ & $\begin{array}{l}-0.574^{*} \\
(0.343)\end{array}$ & $\begin{array}{c}-1.471^{\star * *} \\
(0.395)\end{array}$ & $\begin{array}{l}-0.004 \\
(0.006)\end{array}$ & $\begin{array}{l}-0.036 \\
(0.022)\end{array}$ & $\begin{array}{c}-0.702^{* * *} \\
(0.236)\end{array}$ & $\begin{array}{c}-0.908^{\star * \star} \\
(0.249)\end{array}$ & $\begin{array}{l}0.001 \\
(0.003)\end{array}$ & $\begin{array}{l}-0.010 \\
(0.016)\end{array}$ & $\begin{array}{c}-0.682^{* * *} \\
(0.208)\end{array}$ & $\begin{array}{c}-1.227^{* * *} \\
(0.225)\end{array}$ \\
\hline Pension wealth ${ }^{\star}$ Germany & $\begin{array}{c}-1.683^{* * *} \\
(0.272)\end{array}$ & $\begin{array}{c}-2.756^{\star * *} \\
(0.423)\end{array}$ & $\begin{array}{c}-1.100^{* * *} \\
(0.202)\end{array}$ & $\begin{array}{c}-2.202^{\star \star *} \\
(0.315)\end{array}$ & $\begin{array}{l}-0.002 \\
(0.003)\end{array}$ & $\begin{array}{l}-0.017 \\
(0.017)\end{array}$ & $\begin{array}{c}-0.613^{\star * *} \\
(0.135)\end{array}$ & $\begin{array}{c}-0.756^{\star \star \star} \\
(0.182)\end{array}$ & $\begin{array}{l}0.008^{\star \star \star} \\
(0.002)\end{array}$ & $\begin{array}{l}0.014 \\
(0.012)\end{array}$ & $\begin{array}{c}-0.530^{* * *} \\
(0.117)\end{array}$ & $\begin{array}{c}-1.060^{* * *} \\
(0.157)\end{array}$ \\
\hline Pension wealthFrance & $\begin{array}{l}0.144 \\
(0.194)\end{array}$ & $\begin{array}{l}-0.614^{\star *} \\
(0.310)\end{array}$ & $\begin{array}{l}0.0803 \\
(0.144)\end{array}$ & $\begin{array}{c}-0.678^{\star * *} \\
(0.231)\end{array}$ & $\begin{array}{l}0.007^{* \star \star} \\
(0.002)\end{array}$ & $\begin{array}{l}-0.007 \\
(0.012)\end{array}$ & $\begin{array}{l}-0.0770 \\
(0.0895)\end{array}$ & $\begin{array}{l}-0.292^{* *} \\
(0.119)\end{array}$ & $\begin{array}{l}0.008^{\star \star \star} \\
(0.001)\end{array}$ & $\begin{array}{r}0.027^{\star \star \star} \\
(0.008)\end{array}$ & $\begin{array}{l}-0.362^{* * *} \\
(0.0792)\end{array}$ & $\begin{array}{c}-0.715^{* * *} \\
(0.105)\end{array}$ \\
\hline Pension wealthGreece & $\begin{array}{l}-0.403 \\
(0.756)\end{array}$ & $\begin{array}{l}-0.850 \\
(0.773)\end{array}$ & $\begin{array}{c}0.318 \\
(0.561)\end{array}$ & $\begin{array}{r}-0.0994 \\
(0.574)\end{array}$ & $\begin{array}{l}0.006 \\
(0.007)\end{array}$ & $\begin{array}{l}0.017 \\
(0.028)\end{array}$ & $\begin{array}{l}-0.503 \\
(0.413)\end{array}$ & $\begin{array}{l}-0.591 \\
(0.419)\end{array}$ & $\begin{array}{l}0.010 \\
(0.012)\end{array}$ & $\begin{array}{c}0.039 \\
(0.048)\end{array}$ & $\begin{array}{c}0.288 \\
(0.730)\end{array}$ & $\begin{array}{l}0.186 \\
(0.745)\end{array}$ \\
\hline Pension wealth^ltaly & $\begin{array}{l}0.563^{\star *} \\
(0.258)\end{array}$ & $\begin{array}{l}0.184 \\
(0.277)\end{array}$ & $\begin{array}{l}0.460^{* *} \\
(0.191)\end{array}$ & $\begin{array}{l}0.0931 \\
(0.206)\end{array}$ & $\begin{array}{l}0.016^{\star \star \star} \\
(0.004)\end{array}$ & $\begin{array}{l}0.062^{* * *} \\
(0.014)\end{array}$ & $\begin{array}{l}0.157 \\
(0.128)\end{array}$ & $\begin{array}{l}0.105 \\
(0.130)\end{array}$ & $\begin{array}{l}0.013^{\star \star \star} \\
(0.002)\end{array}$ & $\begin{array}{l}0.047^{\star \star \star} \\
(0.009)\end{array}$ & $\begin{array}{l}0.316^{\star \star \star} \\
(0.117)\end{array}$ & $\begin{array}{l}0.217^{*} \\
(0.118)\end{array}$ \\
\hline Pension wealth ${ }^{*}$ Portugal & $\begin{array}{l}-0.290 \\
(0.306)\end{array}$ & $\begin{array}{l}-0.847^{\star *} \\
(0.358)\end{array}$ & $\begin{array}{c}0.356 \\
(0.227)\end{array}$ & $\begin{array}{l}-0.171 \\
(0.266)\end{array}$ & $\begin{array}{l}0.0007 \\
(0.004)\end{array}$ & $\begin{array}{l}0.017 \\
(0.018)\end{array}$ & $\begin{array}{c}-0.968^{* * *} \\
(0.151)\end{array}$ & $\begin{array}{c}-1.081^{* * *} \\
(0.162)\end{array}$ & $\begin{array}{c}0.010^{\star \star \star} \\
(0.003)\end{array}$ & $\begin{array}{c}0.037^{\star \star \star} \\
(0.012)\end{array}$ & $\begin{array}{c}0.155 \\
(0.157)\end{array}$ & $\begin{array}{l}-0.0154 \\
(0.172)\end{array}$ \\
\hline Belgium & $\begin{array}{c}-24.94^{* * *} \\
(6.108)\end{array}$ & $\begin{array}{c}-15.85^{\star *} \\
(6.179)\end{array}$ & $\begin{array}{c}-15.14^{* * *} \\
(4.535)\end{array}$ & $\begin{array}{c}-9.818^{* *} \\
(4.593)\end{array}$ & $\begin{array}{c}-0.147^{* *} \\
(0.073)\end{array}$ & $\begin{array}{c}-0.545^{\star *} \\
(0.273)\end{array}$ & $\begin{array}{c}-11.32^{\star * *} \\
(3.196)\end{array}$ & $\begin{array}{c}-8.417^{* *} \\
(3.274)\end{array}$ & $\begin{array}{l}0.128^{\star *} \\
(0.058)\end{array}$ & $\begin{array}{c}0.603^{\star \star \star} \\
(0.232)\end{array}$ & $\begin{array}{l}7.675^{\star *} \\
(3.090)\end{array}$ & $\begin{array}{c}9.780^{\star \star \star} \\
(3.245)\end{array}$ \\
\hline Germany & $\begin{array}{c}-29.06^{\star * *} \\
(4.306)\end{array}$ & $\begin{array}{c}-20.37^{\star * *} \\
(4.431)\end{array}$ & $\begin{array}{c}-15.84^{\star \star *} \\
(3.197)\end{array}$ & $\begin{array}{c}-11.18^{\star * *} \\
(3.294)\end{array}$ & $\begin{array}{c}-0.345^{\star \star *} \\
(0.054)\end{array}$ & $\begin{array}{c}-1.451^{\star * *} \\
(0.211)\end{array}$ & $\begin{array}{c}-22.42^{\star * *} \\
(2.299)\end{array}$ & $\begin{array}{c}-20.44^{* * *} \\
(2.408)\end{array}$ & $\begin{array}{c}0.027 \\
(0.045)\end{array}$ & $\begin{array}{c}0.178 \\
(0.182)\end{array}$ & $\begin{array}{c}0.365 \\
(2.330)\end{array}$ & $\begin{array}{c}0.481 \\
(2.508)\end{array}$ \\
\hline France & $\begin{array}{c}-35.78^{\star * *} \\
(4.056)\end{array}$ & $\begin{array}{c}-27.42^{* * *} \\
(4.141)\end{array}$ & $\begin{array}{c}-21.67^{* * *} \\
(3.012)\end{array}$ & $\begin{array}{c}-16.92^{* * *} \\
(3.078)\end{array}$ & $\begin{array}{c}-0.273^{* * *} \\
(0.051)\end{array}$ & $\begin{array}{c}-0.891^{* * *} \\
(0.193)\end{array}$ & $\begin{array}{c}-18.77^{\star \star *} \\
(2.069)\end{array}$ & $\begin{array}{c}-15.74^{* * *} \\
(2.155)\end{array}$ & $\begin{array}{l}0.067 \\
(0.041)\end{array}$ & $\begin{array}{l}0.293^{*} \\
(0.168)\end{array}$ & $\begin{array}{l}4.868^{\star \star} \\
(2.141)\end{array}$ & $\begin{array}{l}5.336^{\star \star} \\
(2.304)\end{array}$ \\
\hline Greece & $\begin{array}{c}-37.70^{\star * \star} \\
(6.548)\end{array}$ & $\begin{array}{c}-31.40^{\star \star \star} \\
(6.647)\end{array}$ & $\begin{array}{c}-26.03^{\star \star *} \\
(4.862)\end{array}$ & $\begin{array}{c}-23.40^{\star \star \star} \\
(4.941)\end{array}$ & $\begin{array}{c}-0.235^{\star \star \star} \\
(0.069)\end{array}$ & $\begin{array}{l}-0.974^{\star \star *} \\
(0.2268)\end{array}$ & $\begin{array}{c}-18.17^{\star \star \star} \\
(3.531)\end{array}$ & $\begin{array}{c}-16.35^{\star \star \star} \\
(3.658)\end{array}$ & $\begin{array}{c}-0.294^{\star \star \star} \\
(0.108)\end{array}$ & $\begin{array}{c}-1.126^{\star \star \star} \\
(0.429)\end{array}$ & $\begin{array}{c}-16.96^{\star * \star} \\
(6.359)\end{array}$ & $\begin{array}{c}-18.15^{* * *} \\
(6.507)\end{array}$ \\
\hline Italy & $\begin{array}{c}-40.71^{\star * *} \\
(4.387)\end{array}$ & $\begin{array}{c}-35.98^{\star * *} \\
(4.637)\end{array}$ & $\begin{array}{c}-27.38^{\star \star *} \\
(3.257)\end{array}$ & $\begin{array}{c}-26.45^{\star * *} \\
(3.447)\end{array}$ & $\begin{array}{c}-0.270^{\star * \star} \\
(0.055)\end{array}$ & $\begin{array}{c}-1.181^{* * *} \\
(0.225)\end{array}$ & $\begin{array}{c}-17.61^{* * *} \\
(2.269)\end{array}$ & $\begin{array}{c}-16.12^{\star * *} \\
(2.499)\end{array}$ & $\begin{array}{l}-0.067 \\
(0.046)\end{array}$ & $\begin{array}{l}-0.258 \\
(0.193)\end{array}$ & $\begin{array}{l}-5.579^{\star *} \\
(2.381)\end{array}$ & $\begin{array}{c}-7.643^{* * *} \\
(2.665)\end{array}$ \\
\hline Luxembourg & ref. & ref. & ref. & ref. & ref. & ref. & ref. & ref. & ref. & ref. & ref. & ref. \\
\hline Portugal & $\begin{array}{c}-34.88^{\star \star *} \\
(4.262)\end{array}$ & $\begin{array}{c}-29.06^{\star * *} \\
(4.445)\end{array}$ & $\begin{array}{c}-25.31^{\star * *} \\
(3.164)\end{array}$ & $\begin{array}{c}-23.38^{\star * *} \\
(3.304)\end{array}$ & $\begin{array}{c}0.044 \\
(0.052)\end{array}$ & $\begin{array}{l}-0.068 \\
(0.212)\end{array}$ & $\begin{array}{c}-9.116^{* * *} \\
(2.154)\end{array}$ & $\begin{array}{c}-7.304^{* * *} \\
(2.356)\end{array}$ & $\begin{array}{l}-0.044 \\
(0.045)\end{array}$ & $\begin{array}{l}-0.171 \\
(0.190)\end{array}$ & $\begin{array}{c}-4.742^{* *} \\
(2.409)\end{array}$ & $\begin{array}{l}-6.184^{\star *} \\
(2.667)\end{array}$ \\
\hline Other control variables & yes & yes & yes & yes & yes & yes & yes & yes & yes & yes & yes & yes \\
\hline Country fixed effects & yes & yes & yes & yes & yes & yes & yes & yes & yes & yes & yes & yes \\
\hline
\end{tabular}

Dependent variable: net wealth (columns 1, estimated by OLS and IV regressions), financial wealth (columns 2, estimated by OLS and IV regressions), housing wealth (columns 3, probability of owning real estate property estimated by Probit and IV Probit and value of real estate property estimated by Tobit and IV Tobit), risky financial assets (columns 4, probability of holding risky financial assets estimated by Probit and IV Probit, amount of risky financial assets estimated by Tobit and IV Tobit). Control variables: age, gender, education and income of the reference person, household composition (number of children, number of household members in employment), having received any substantial gifts or inheritances, having been credit constrained within the last three years, future income expectations and willingness to take financial risks. Countries: Belgium, Germany, France, Greece, Italy, Luxembourg and Portugal. Estimated coefficients (and standard errors) for OLS, IV, Tobit, and IV Tobit regressions. Marginal effects (and standard errors) for Probit and IV Probit. Units for net wealth, financial wealth, housing wealth, risky financial assets, pension wealth and income: $10^{4}$ euro. Pension wealth is adjusted by Gale's $Q$ factor. Significant at ${ }^{* * *} 1 \%$, ${ }^{* *} 5 \%$ and *10\%. Number of observations: 10,129 . 
Table 2d. Estimates of the pension-savings offset: accounting for heterogeneity across age groups, willingness to take risks and countries

\begin{tabular}{|c|c|c|c|c|c|c|c|c|c|c|c|c|}
\hline & \multicolumn{2}{|c|}{$\begin{array}{l}\text { Net wealth } \\
\text { (1) }\end{array}$} & \multicolumn{2}{|c|}{$\begin{array}{l}\text { Financial wealth } \\
\text { (2) }\end{array}$} & \multicolumn{4}{|c|}{$\begin{array}{l}\text { Housing wealth } \\
\text { (3) }\end{array}$} & \multicolumn{4}{|c|}{$\begin{array}{l}\text { Risky financial assets } \\
\text { (4) }\end{array}$} \\
\hline & $\begin{array}{c}\text { OLS } \\
\text { Coef. } \\
\text { (Std. Err.) }\end{array}$ & $\begin{array}{c}\text { IV } \\
\text { Coef. } \\
\text { (Std. Err.) }\end{array}$ & $\begin{array}{c}\text { OLS } \\
\text { Coef. } \\
\text { (Std. Err.) }\end{array}$ & $\begin{array}{c}\mathbf{I V} \\
\text { Coef. } \\
\text { (Std. Err.) }\end{array}$ & $\begin{array}{c}\text { Probit } \\
\text { Marginal Ef. } \\
\text { (Std. Err.) }\end{array}$ & $\begin{array}{l}\text { IV Probit } \\
\text { Marginal Ef. } \\
\text { (Std. Err.) }\end{array}$ & $\begin{array}{c}\text { Tobit } \\
\text { Coef. } \\
\text { (Std. Err.) } \\
\end{array}$ & $\begin{array}{c}\text { IV Tobit } \\
\text { Coef. } \\
\text { (Std. Err.) }\end{array}$ & $\begin{array}{c}\text { Probit } \\
\text { Marginal Ef. } \\
\text { (Std. Err.) }\end{array}$ & $\begin{array}{c}\text { IV Probit } \\
\text { Marginal Ef. } \\
\text { (Std. Err.) }\end{array}$ & $\begin{array}{c}\text { Tobit } \\
\text { Coef. } \\
\text { (Std. Err.) } \\
\end{array}$ & $\begin{array}{l}\text { IV Tobit } \\
\text { Coef. } \\
\text { (Std. Err.) }\end{array}$ \\
\hline Pension wealth & $\begin{array}{c}-2.625^{\star \star \star} \\
(0.262)\end{array}$ & $\begin{array}{l}-2.930^{\star * *} \\
(0.362)\end{array}$ & $\begin{array}{c}-1.795^{\star \star \star} \\
(0.195)\end{array}$ & $\begin{array}{l}-2.356^{\star \star \star} \\
(0.270)\end{array}$ & $\begin{array}{c}-0.007^{* *} \\
(0.003)\end{array}$ & $\begin{array}{c}-0.040^{\star \star *} \\
(0.016)\end{array}$ & $\begin{array}{c}-0.787^{\star \star *} \\
(0.136)\end{array}$ & $\begin{array}{c}-0.751^{\star \star \star} \\
(0.164)\end{array}$ & $\begin{array}{l}-0.001 \\
(0.003)\end{array}$ & $\begin{array}{l}-0.014 \\
(0.012)\end{array}$ & $\begin{array}{l}-0.707^{\star * *} \\
(0.135)\end{array}$ & $\begin{array}{c}-1.143^{\star \star \star} \\
(0.165)\end{array}$ \\
\hline Pension wealth age[35 -39] & $\begin{array}{l}0.276 \\
(0.204)\end{array}$ & $\begin{array}{c}0.309 \\
(0.208)\end{array}$ & $\begin{array}{c}0.144 \\
(0.152)\end{array}$ & $\begin{array}{l}0.202 \\
(0.155)\end{array}$ & $\begin{array}{l}-0.002 \\
(0.002)\end{array}$ & $\begin{array}{l}-0.002 \\
(0.008)\end{array}$ & $\begin{array}{c}0.00762 \\
(0.109)\end{array}$ & $\begin{array}{l}0.0129 \\
(0.110)\end{array}$ & $\begin{array}{c}0.001 \\
(0.002)\end{array}$ & $\begin{array}{c}0.004 \\
(0.008)\end{array}$ & $\begin{array}{l}0.0995 \\
(0.115)\end{array}$ & $\begin{array}{c}0.145 \\
(0.118)\end{array}$ \\
\hline Pension wealth* age[40 -44] & $\begin{array}{c}0.824^{\star \star \star} \\
(0.194)\end{array}$ & $\begin{array}{c}0.834^{\star \star \star} \\
(0.201)\end{array}$ & $\begin{array}{c}0.381^{\star \star \star} \\
(0.144)\end{array}$ & $\begin{array}{c}0.461^{\star \star \star} \\
(0.150)\end{array}$ & $\begin{array}{l}-0.0005 \\
(0.002)\end{array}$ & $\begin{array}{l}0.001 \\
(0.008)\end{array}$ & $\begin{array}{c}0.306^{\star * \star} \\
(0.103)\end{array}$ & $\begin{array}{c}0.273^{\star \star \star} \\
(0.105)\end{array}$ & $\begin{array}{l}0.003^{\star} \\
(0.002)\end{array}$ & $\begin{array}{l}0.015^{\star} \\
(0.007)\end{array}$ & $\begin{array}{c}0.300^{\star \star \star} \\
(0.108)\end{array}$ & $\begin{array}{c}0.368^{\star \star \star} \\
(0.112)\end{array}$ \\
\hline Pension wealth* age[45 -49] & $\begin{array}{l}1.679^{\star \star \star} \\
(0.192)\end{array}$ & $\begin{array}{c}1.774^{\star \star \star} \\
(0.202)\end{array}$ & $\begin{array}{c}0.873^{\star \star \star} \\
(0.143)\end{array}$ & $\begin{array}{l}1.010^{\star \star \star} \\
(0.150)\end{array}$ & $\begin{array}{l}0.0002 \\
(0.002)\end{array}$ & $\begin{array}{c}0.005 \\
(0.008)\end{array}$ & $\begin{array}{c}0.655^{\star \star \star} \\
(0.102)\end{array}$ & $\begin{array}{l}0.655^{\star \star \star} \\
(0.104)\end{array}$ & $\begin{array}{c}0.002 \\
(0.002)\end{array}$ & $\begin{array}{c}0.009 \\
(0.007)\end{array}$ & $\begin{array}{c}0.358^{\star \star \star} \\
(0.107)\end{array}$ & $\begin{array}{c}0.428^{\star \star \star} \\
(0.111)\end{array}$ \\
\hline Pension wealth age[50 -54] & $\begin{array}{c}0.795^{\star \star \star} \\
(0.193)\end{array}$ & $\begin{array}{c}0.889^{\star \star \star} \\
(0.207)\end{array}$ & $\begin{array}{c}0.226 \\
(0.144)\end{array}$ & $\begin{array}{l}0.395^{\star \star} \\
(0.154)\end{array}$ & $\begin{array}{r}-0.0001 \\
(0.002)\end{array}$ & $\begin{array}{c}0.007 \\
(0.009)\end{array}$ & $\begin{array}{c}0.385^{\star \star \star} \\
(0.102)\end{array}$ & $\begin{array}{c}0.367^{\star \star \star} \\
(0.105)\end{array}$ & $\begin{array}{c}0.001 \\
(0.002)\end{array}$ & $\begin{array}{c}0.005 \\
(0.007)\end{array}$ & $\begin{array}{l}0.181^{\star} \\
(0.107)\end{array}$ & $\begin{array}{l}0.257^{\star *} \\
(0.112)\end{array}$ \\
\hline Pension wealth* High or very high risk & $\begin{array}{c}0.865^{\star \star \star} \\
(0.152)\end{array}$ & $\begin{array}{c}0.893^{\star \star \star} \\
(0.155)\end{array}$ & $\begin{array}{c}0.587^{\star \star \star} \\
(0.113)\end{array}$ & $\begin{array}{l}0.630^{\star \star \star} \\
(0.116)\end{array}$ & $\begin{array}{l}-0.002 \\
(0.002)\end{array}$ & $\begin{array}{l}-0.006 \\
(0.008)\end{array}$ & $\begin{array}{l}0.189^{\star \star} \\
(0.0781)\end{array}$ & $\begin{array}{l}0.198^{\star \star} \\
(0.0791)\end{array}$ & $\begin{array}{c}0.005^{\star \star \star} \\
(0.002)\end{array}$ & $\begin{array}{c}0.020^{\star \star \star} \\
(0.006)\end{array}$ & $\begin{array}{l}0.407^{\star \star \star} \\
(0.0659)\end{array}$ & $\begin{array}{l}0.465^{\star \star \star} \\
(0.0674)\end{array}$ \\
\hline Pension wealth* Average risk & $\begin{array}{l}0.720^{* \star \star} \\
(0.0920)\end{array}$ & $\begin{array}{l}0.702^{\star \star \star} \\
(0.0945)\end{array}$ & $\begin{array}{l}0.567^{\star \star \star} \\
(0.0685)\end{array}$ & $\begin{array}{l}0.579^{\star \star \star} \\
(0.0704)\end{array}$ & $\begin{array}{l}-0.002 \\
(0.001)\end{array}$ & $\begin{array}{l}-0.006 \\
(0.005)\end{array}$ & $\begin{array}{l}0.0845^{\star} \\
(0.0468)\end{array}$ & $\begin{array}{c}0.0677 \\
(0.0477)\end{array}$ & $\begin{array}{l}0.002^{* *} \\
(0.001)\end{array}$ & $\begin{array}{l}0.008^{\star *} \\
(0.003)\end{array}$ & $\begin{array}{l}0.143^{\star * *} \\
(0.0426)\end{array}$ & $\begin{array}{l}0.161^{* \star \star} \\
(0.0441)\end{array}$ \\
\hline Pension wealth*Belgium & $\begin{array}{l}-0.867^{\star} \\
(0.458)\end{array}$ & $\begin{array}{c}-1.911^{\star \star \star} \\
(0.530)\end{array}$ & $\begin{array}{l}-0.419 \\
(0.341)\end{array}$ & $\begin{array}{l}-1.424^{* \star *} \\
(0.395)\end{array}$ & $\begin{array}{l}-0.004 \\
(0.006)\end{array}$ & $\begin{array}{l}-0.038^{*} \\
(0.023)\end{array}$ & $\begin{array}{l}-0.642^{\star \star \star} \\
(0.234)\end{array}$ & $\begin{array}{l}-0.859^{\star \star \star} \\
(0.247)\end{array}$ & $\begin{array}{l}0.0009 \\
(0.004)\end{array}$ & $\begin{array}{l}-0.013 \\
(0.017)\end{array}$ & $\begin{array}{l}-0.636^{\star \star *} \\
(0.206)\end{array}$ & $\begin{array}{c}-1.221^{\star \star \star} \\
(0.222)\end{array}$ \\
\hline Pension wealth*Germany & $\begin{array}{c}-1.513^{* \star \star} \\
(0.273)\end{array}$ & $\begin{array}{c}-2.716^{\star \star \star} \\
(0.425)\end{array}$ & $\begin{array}{c}-0.901^{* \star *} \\
(0.203)\end{array}$ & $\begin{array}{l}-2.115^{\star \star \star} \\
(0.316)\end{array}$ & $\begin{array}{l}-0.003 \\
(0.003)\end{array}$ & $\begin{array}{l}-0.018 \\
(0.017)\end{array}$ & $\begin{array}{c}-0.593^{\star \star \star} \\
(0.135)\end{array}$ & $\begin{array}{c}-0.738^{\star \star \star} \\
(0.180)\end{array}$ & $\begin{array}{c}0.007^{\star \star \star} \\
(0.002)\end{array}$ & $\begin{array}{l}0.010 \\
(0.013)\end{array}$ & $\begin{array}{c}-0.494^{\star \star \star} \\
(0.116)\end{array}$ & $\begin{array}{c}-1.078^{\star \star \star} \\
(0.156)\end{array}$ \\
\hline Pension wealth*France & $\begin{array}{l}0.397^{\star \star} \\
(0.194)\end{array}$ & $\begin{array}{l}-0.500 \\
(0.310)\end{array}$ & $\begin{array}{l}0.304^{\star *} \\
(0.145)\end{array}$ & $\begin{array}{l}-0.556^{\star *} \\
(0.231)\end{array}$ & $\begin{array}{l}0.006^{\star *} \\
(0.002)\end{array}$ & $\begin{array}{l}-0.011 \\
(0.012)\end{array}$ & $\begin{array}{c}0.0102 \\
(0.0908)\end{array}$ & $\begin{array}{l}-0.206^{*} \\
(0.118)\end{array}$ & $\begin{array}{c}0.009^{\star \star \star} \\
(0.001)\end{array}$ & $\begin{array}{c}0.028^{\star \star \star} \\
(0.008)\end{array}$ & $\begin{array}{l}-0.287^{\star \star \star} \\
(0.0805)\end{array}$ & $\begin{array}{c}-0.654^{\star \star \star} \\
(0.106)\end{array}$ \\
\hline Pension wealth ${ }^{\star}$ Greece & $\begin{array}{l}0.127 \\
(0.750)\end{array}$ & $\begin{array}{l}-0.389 \\
(0.764)\end{array}$ & $\begin{array}{l}0.640 \\
(0.558)\end{array}$ & $\begin{array}{l}0.201 \\
(0.570)\end{array}$ & $\begin{array}{l}0.005 \\
(0.007)\end{array}$ & $\begin{array}{l}0.014 \\
(0.028)\end{array}$ & $\begin{array}{l}-0.265 \\
(0.411)\end{array}$ & $\begin{array}{l}-0.375 \\
(0.416)\end{array}$ & $\begin{array}{l}0.010 \\
(0.012)\end{array}$ & $\begin{array}{l}0.037 \\
(0.048)\end{array}$ & $\begin{array}{l}0.418 \\
(0.712)\end{array}$ & $\begin{array}{l}0.341 \\
(0.723)\end{array}$ \\
\hline Pension wealth*|taly & $\begin{array}{c}0.681^{* \star \star} \\
(0.255)\end{array}$ & $\begin{array}{c}0.237 \\
(0.276)\end{array}$ & $\begin{array}{c}0.561^{* \star *} \\
(0.190)\end{array}$ & $\begin{array}{c}0.147 \\
(0.205)\end{array}$ & $\begin{array}{c}0.016^{\star \star \star} \\
(0.004)\end{array}$ & $\begin{array}{c}0.060^{\star \star \star} \\
(0.014)\end{array}$ & $\begin{array}{l}0.243^{*} \\
(0.128)\end{array}$ & $\begin{array}{c}0.181 \\
(0.129)\end{array}$ & $\begin{array}{c}0.013^{\star \star \star} \\
(0.002)\end{array}$ & $\begin{array}{c}0.046^{\star \star \star} \\
(0.009)\end{array}$ & $\begin{array}{c}0.366^{* \star *} \\
(0.116)\end{array}$ & $\begin{array}{l}0.283^{\star \star} \\
(0.117)\end{array}$ \\
\hline Pension wealthPortugal & $\begin{array}{l}0.0979 \\
(0.306)\end{array}$ & $\begin{array}{l}-0.554 \\
(0.353)\end{array}$ & $\begin{array}{c}0.616^{\star \star \star} \\
(0.228)\end{array}$ & $\begin{array}{l}0.0487 \\
(0.263)\end{array}$ & $\begin{array}{l}0.0001 \\
(0.004)\end{array}$ & $\begin{array}{c}0.014 \\
(0.018)\end{array}$ & $\begin{array}{c}-0.789^{\star \star \star} \\
(0.154)\end{array}$ & $\begin{array}{c}-0.918^{\star \star \star} \\
(0.163)\end{array}$ & $\begin{array}{c}0.011^{\star \star \star} \\
(0.003)\end{array}$ & $\begin{array}{c}0.039^{\star \star \star} \\
(0.012)\end{array}$ & $\begin{array}{l}0.291^{*} \\
(0.158)\end{array}$ & $\begin{array}{c}0.126 \\
(0.172) \\
\end{array}$ \\
\hline
\end{tabular}


Table 2d (continued). Estimates of the pension-savings offset: accounting for heterogeneity across age groups, willingness to take risks and countries

\begin{tabular}{|c|c|c|c|c|c|c|c|c|c|c|c|c|}
\hline & \multicolumn{2}{|c|}{$\begin{array}{l}\text { Net wealth } \\
\text { (1) }\end{array}$} & \multicolumn{2}{|c|}{$\begin{array}{l}\text { Financial wealth } \\
\text { (2) }\end{array}$} & \multicolumn{4}{|c|}{$\begin{array}{l}\text { Housing wealth } \\
\text { (3) }\end{array}$} & \multicolumn{4}{|c|}{$\begin{array}{l}\text { Risky financial assets } \\
\text { (4) }\end{array}$} \\
\hline & $\begin{array}{c}\text { OLS } \\
\text { Coef. } \\
\text { (Std. Err.) }\end{array}$ & $\begin{array}{c}\text { IV } \\
\text { Coef. } \\
\text { (Std. Err.) }\end{array}$ & $\begin{array}{c}\text { OLS } \\
\text { Coef. } \\
\text { (Std. Err.) }\end{array}$ & $\begin{array}{c}\text { IV } \\
\text { Coef. } \\
\text { (Std. Err.) }\end{array}$ & $\begin{array}{c}\text { Probit } \\
\text { Marginal Ef. } \\
\text { (Std. Err.) }\end{array}$ & $\begin{array}{l}\text { IV Probit } \\
\text { Marginal Ef. } \\
\text { (Std. Err.) }\end{array}$ & $\begin{array}{c}\text { Tobit } \\
\text { Coef. } \\
\text { (Std. Err.) }\end{array}$ & $\begin{array}{l}\text { IV Tobit } \\
\text { Coef. } \\
\text { (Std. Err.) }\end{array}$ & $\begin{array}{c}\text { Probit } \\
\text { Marginal Ef. } \\
\text { (Std. Err.) }\end{array}$ & $\begin{array}{l}\text { IV Probit } \\
\text { Marginal Ef. } \\
\text { (Std. Err.) }\end{array}$ & $\begin{array}{c}\text { Tobit } \\
\text { Coef. } \\
\text { (Std. Err.) }\end{array}$ & $\begin{array}{l}\text { IV Tobit } \\
\text { Coef. } \\
\text { (Std. Err.) }\end{array}$ \\
\hline age[30 -34] & ref. & ref. & ref. & ref. & ref. & ref. & ref. & ref. & ref. & ref. & ref. & ref. \\
\hline age[35 -39] & $\begin{array}{c}- \\
1.240 \\
(2.210)\end{array}$ & $\begin{array}{c}- \\
1.607 \\
(2.226)\end{array}$ & $\begin{array}{c}- \\
0.804 \\
(1.644)\end{array}$ & $\begin{array}{c}- \\
1.130 \\
(1.659)\end{array}$ & $\begin{array}{c}- \\
0.082^{\star * *} \\
(0.023)\end{array}$ & $\begin{array}{c}0.291^{\star \star *} \\
(0.084)\end{array}$ & $\begin{array}{c}- \\
3.605^{\star \star *} \\
(1.244)\end{array}$ & $\begin{array}{c}- \\
3.638^{\star \star *} \\
(1.249)\end{array}$ & $\begin{array}{c}- \\
0.007 \\
(0.025)\end{array}$ & $\begin{array}{c}- \\
0.033 \\
(0.095)\end{array}$ & $\begin{array}{c}- \\
1.122 \\
(1.404)\end{array}$ & $\begin{array}{c}- \\
1.393 \\
(1.418)\end{array}$ \\
\hline age[40 -44] & $\begin{array}{c}0.408 \\
(2.109)\end{array}$ & $\begin{array}{c}1.463 \\
(2.130)\end{array}$ & $\begin{array}{l}-0.0128 \\
(1.569)\end{array}$ & $\begin{array}{c}0.686 \\
(1.587)\end{array}$ & $\begin{array}{c}0.102^{* \star *} \\
(0.022)\end{array}$ & $\begin{array}{c}0.399^{* \star *} \\
(0.082)\end{array}$ & $\begin{array}{c}4.770^{\star \star *} \\
(1.184)\end{array}$ & $\begin{array}{c}5.175^{\star \star \star} \\
(1.190)\end{array}$ & $\begin{array}{c}0.014 \\
(0.023)\end{array}$ & $\begin{array}{l}0.067 \\
(0.091)\end{array}$ & $\begin{array}{c}0.676 \\
(1.324)\end{array}$ & $\begin{array}{c}1.159 \\
(1.340)\end{array}$ \\
\hline age[45 -49] & $\begin{array}{l}-4.057^{\star} \\
(2.115)\end{array}$ & $\begin{array}{l}-3.364 \\
(2.146)\end{array}$ & $\begin{array}{l}-2.962^{*} \\
(1.574)\end{array}$ & $\begin{array}{l}-2.235 \\
(1.599)\end{array}$ & $\begin{array}{c}0.121^{\star \star \star} \\
(0.023)\end{array}$ & $\begin{array}{c}0.487^{\star \star \star} \\
(0.085)\end{array}$ & $\begin{array}{c}3.963^{\star \star \star} \\
(1.183)\end{array}$ & $\begin{array}{c}4.155^{\star \star \star} \\
(1.197)\end{array}$ & $\begin{array}{l}0.045^{\star *} \\
(0.024)\end{array}$ & $\begin{array}{l}0.190^{\star *} \\
(0.091)\end{array}$ & $\begin{array}{c}1.515 \\
(1.313)\end{array}$ & $\begin{array}{l}2.418^{\star} \\
(1.343)\end{array}$ \\
\hline age[50 -54] & $\begin{array}{c}8.636^{* \star *} \\
(2.155)\end{array}$ & $\begin{array}{l}9.629^{\star * *} \\
(2.187)\end{array}$ & $\begin{array}{l}5.202^{* * *} \\
(1.604)\end{array}$ & $\begin{array}{l}5.935^{\star * \star} \\
(1.630)\end{array}$ & $\begin{array}{c}0.163^{\star \star \star} \\
(0.024)\end{array}$ & $\begin{array}{l}0.607^{* \star *} \\
(0.089)\end{array}$ & $\begin{array}{l}9.508^{* \star *} \\
(1.203)\end{array}$ & $\begin{array}{l}9.914^{* * *} \\
(1.220)\end{array}$ & $\begin{array}{l}0.061^{* \star *} \\
(0.024)\end{array}$ & $\begin{array}{c}0.263^{* \star *} \\
(0.093)\end{array}$ & $\begin{array}{l}5.804^{* \star *} \\
(1.319)\end{array}$ & $\begin{array}{c}6.866^{* \star \star} \\
(1.355)\end{array}$ \\
\hline High or very high risk & $\begin{array}{l}0.0750 \\
(2.750)\end{array}$ & $\begin{array}{c}0.00731 \\
(2.767)\end{array}$ & $\begin{array}{l}-1.364 \\
(2.046)\end{array}$ & $\begin{array}{l}-1.582 \\
(2.062)\end{array}$ & $\begin{array}{c}0.037 \\
(0.031)\end{array}$ & $\begin{array}{c}0.127^{\star \star \star} \\
(0.118)\end{array}$ & $\begin{array}{l}2.588^{\star} \\
(1.479)\end{array}$ & $\begin{array}{l}2.582^{*} \\
(1.483)\end{array}$ & $\begin{array}{c}0.162^{\star \star *} \\
(0.028)\end{array}$ & $\begin{array}{c}0.623^{\star \star *} \\
(0.107)\end{array}$ & $\begin{array}{c}6.573^{\star \star \star} \\
(1.355)\end{array}$ & $\begin{array}{l}6.103^{\star \star \star} \\
(1.361)\end{array}$ \\
\hline Average risk & $\begin{array}{l}-2.773^{*} \\
(1.475)\end{array}$ & $\begin{array}{l}-2.550^{*} \\
(1.494)\end{array}$ & $\begin{array}{c}-2.972^{* \star *} \\
(1.098)\end{array}$ & $\begin{array}{c}-3.082^{* \star *} \\
(1.114)\end{array}$ & $\begin{array}{c}0.026 \\
(0.017)\end{array}$ & $\begin{array}{l}0.101 \\
(0.063)\end{array}$ & $\begin{array}{c}1.120 \\
(0.785)\end{array}$ & $\begin{array}{l}1.347^{*} \\
(0.791)\end{array}$ & $\begin{array}{c}0.174^{\star \star *} \\
(0.014)\end{array}$ & $\begin{array}{c}0.668^{* \star *} \\
(0.054)\end{array}$ & $\begin{array}{c}6.543^{\star \star \star} \\
(0.758)\end{array}$ & $\begin{array}{c}6.456^{* * *} \\
(0.769)\end{array}$ \\
\hline No risk & ref. & ref. & ref. & ref. & $\begin{array}{c}\text { ref. } \\
-\end{array}$ & ref. & $\begin{array}{c}\text { ref. } \\
-\end{array}$ & $\begin{array}{c}\text { ref. } \\
-\end{array}$ & ref. & ref. & ref. & ref. \\
\hline Belgium & $\begin{array}{c}-40.74^{\star \star \star} \\
(6.253)\end{array}$ & $\begin{array}{c}-32.04^{\star \star \star} \\
(6.382)\end{array}$ & $\begin{array}{c}-23.93^{\star \star \star} \\
(4.653)\end{array}$ & $\begin{array}{c}-19.95^{\star \star \star} \\
(4.756)\end{array}$ & $\begin{array}{c}-0.140^{* *} \\
(0.076)\end{array}$ & $\begin{array}{l}-0.518^{*} \\
(0.290)\end{array}$ & $\begin{array}{c}-17.37^{\star \star \star} \\
(3.305)\end{array}$ & $\begin{array}{c}-14.02^{\star \star \star} \\
(3.418)\end{array}$ & $\begin{array}{l}0.120^{*} \\
(0.062)\end{array}$ & $\begin{array}{l}0511^{\star *} \\
(0.248)\end{array}$ & $\begin{array}{c}4.303 \\
(3.194)\end{array}$ & $\begin{array}{l}3.988 \\
(3.407)\end{array}$ \\
\hline Germany & $\begin{array}{l}-46.18^{\star \star *} \\
(4.602)\end{array}$ & $\begin{array}{c}-38.65^{\star \star *} \\
(4.874)\end{array}$ & $\begin{array}{l}-25.28^{* * *} \\
(3.424)\end{array}$ & $\begin{array}{l}-22.44^{\star \star *} \\
(3.632)\end{array}$ & $\begin{array}{c}-0.336^{* * *} \\
(0.058)\end{array}$ & $\begin{array}{c}-1.413^{* \star *} \\
(0.233)\end{array}$ & $\begin{array}{l}-28.35^{\star \star *} \\
(2.460)\end{array}$ & $\begin{array}{c}-26.03^{\star * *} \\
(2.616)\end{array}$ & $\begin{array}{l}0.016 \\
(0.049)\end{array}$ & $\begin{array}{c}0.064 \\
(0.203)\end{array}$ & $\begin{array}{l}-3.104 \\
(2.476)\end{array}$ & $\begin{array}{l}-5.790^{\star *} \\
(2.763)\end{array}$ \\
\hline France & $\begin{array}{c}-52.73^{\star \star \star} \\
(4.346)\end{array}$ & $\begin{array}{c}-44.71^{* \star *} \\
(4.493)\end{array}$ & $\begin{array}{c}-31.23^{* \star *} \\
(3.234)\end{array}$ & $\begin{array}{l}-27.73^{\star \star \star} \\
(3.348)\end{array}$ & $\begin{array}{c}-0.262^{* \star *} \\
(0.056)\end{array}$ & $\begin{array}{c}-0.833^{* * *} \\
(0.216)\end{array}$ & $\begin{array}{c}-25.10^{* \star *} \\
(2.271)\end{array}$ & $\begin{array}{l}-21.76^{* \star *} \\
(2.406)\end{array}$ & $\begin{array}{c}0.049 \\
(0.046)\end{array}$ & $\begin{array}{c}0.158 \\
(0.191)\end{array}$ & $\begin{array}{c}1.042 \\
(2.329)\end{array}$ & $\begin{array}{l}-1.211 \\
(2.595)\end{array}$ \\
\hline Greece & $\begin{array}{c}-55.85^{\star \star \star} \\
(6.737)\end{array}$ & $\begin{array}{c}-50.34^{\star \star \star} \\
(6.956)\end{array}$ & $\begin{array}{c}-35.86^{\star \star \star} \\
(5.013)\end{array}$ & $\begin{array}{c}-34.96^{\star \star \star} \\
(5.183)\end{array}$ & $\begin{array}{c}-0.224^{* \star *} \\
(0.074)\end{array}$ & $\begin{array}{l}-0.927^{\star \star \star} \\
(0.292)\end{array}$ & $\begin{array}{c}-25.54^{\star \star \star} \\
(3.673)\end{array}$ & $\begin{array}{c}-23.20^{* \star *} \\
(3.853)\end{array}$ & $\begin{array}{c}-0.305^{\star \star \star} \\
(0.110)\end{array}$ & $\begin{array}{c}-1.218^{\star \star \star} \\
(0.437)\end{array}$ & $\begin{array}{c}-20.75^{\star \star *} \\
(6.282)\end{array}$ & $\begin{array}{c}-24.64^{* * *} \\
(6.454)\end{array}$ \\
\hline Italy & $\begin{array}{c}-56.01^{\star \star \star} \\
(4.616)\end{array}$ & $\begin{array}{c}-52.37^{\star \star \star} \\
(5.073)\end{array}$ & $\begin{array}{c}-35.47^{\star \star \star} \\
(3.435)\end{array}$ & $\begin{array}{c}-36.34^{* * *} \\
(3.780)\end{array}$ & $\begin{array}{c}-0.263^{\star \star \star} \\
(0.059)\end{array}$ & $\begin{array}{c}-1.138^{\star * \star} \\
(0.249)\end{array}$ & $\begin{array}{c}-23.88^{\star \star \star} \\
(2.432)\end{array}$ & $\begin{array}{c}-21.96^{\star \star \star} \\
(2.725)\end{array}$ & $\begin{array}{l}-0.074 \\
(0.049)\end{array}$ & $\begin{array}{c}-0.363^{*} \\
(0.214)\end{array}$ & $\begin{array}{c}-8.855^{\star \star \star} \\
(2.512)\end{array}$ & $\begin{array}{c}-13.78^{\star * *} \\
(2.894)\end{array}$ \\
\hline Luxembourg & ref. & ref. & $\begin{array}{l}\text { ref. } \\
-\end{array}$ & $\begin{array}{l}\text { ref. } \\
-\end{array}$ & $\begin{array}{l}\text { ref. } \\
-\end{array}$ & ref. & ref. & ref. & ref. & ref. & ref. & ref. \\
\hline Portugal & $\begin{array}{c}-53.19^{\star \star \star} \\
(4.623)\end{array}$ & $\begin{array}{c}-48.30^{\star \star \star} \\
(5.011)\end{array}$ & $\begin{array}{c}-35.32^{\star \star *} \\
(3.440)\end{array}$ & $\begin{array}{c}-35.30^{\star \star *} \\
(3.734)\end{array}$ & $\begin{array}{c}0.055 \\
(0.058)\end{array}$ & $\begin{array}{l}-0.014 \\
(0.244)\end{array}$ & $\begin{array}{c}-16.35^{\star \star \star} \\
(2.419)\end{array}$ & $\begin{array}{c}-14.08^{* \star *} \\
(2.692)\end{array}$ & $\begin{array}{l}-0.065 \\
(0.050)\end{array}$ & $\begin{array}{c}-0.322^{* *} \\
(0.215)\end{array}$ & $\begin{array}{c}-9.161^{\star \star *} \\
(2.620)\end{array}$ & $\begin{array}{c}-13.51^{* \star *} \\
(2.982)\end{array}$ \\
\hline Other control variables & yes & yes & yes & yes & yes & yes & yes & yes & yes & yes & yes & yes \\
\hline Country fixed effects & yes & yes & yes & yes & yes & yes & yes & yes & yes & yes & yes & yes \\
\hline
\end{tabular}

Dependent variable: net wealth (columns 1, estimated by OLS and IV regressions), financial wealth (columns 2, estimated by OLS and IV regressions), housing wealth (columns 3 , probability of owning real estate property estimated by Probit and IV Probit and value of real estate property estimated by Tobit and IV Tobit), risky financial assets (columns 4, probability of holding risky financial assets estimated by Probit and IV Probit, amount of risky financial assets estimated by Tobit and IV Tobit). Control variables: age, gender, education and income of the reference person, household composition (number of children, number of household members in employment), having received any substantial gifts or inheritances, having been credit constrained within the last three years, future income expectations and willingness to take financial risks. Countries: Belgium, Germany, France, Greece, Italy, Luxembourg and Portugal. Estimated coefficients (and standard errors) for OLS, IV, Tobit, and IV Tobit regressions. Marginal effects (and standard errors) for Probit and IV Probit. Units for net wealth, financial wealth, housing wealth, risky financial assets, pension wealth and income: $10^{4}$ euro. Pension wealth is adjusted by Gale's $Q$ factor. Significant at $* * * 1 \%, * * 5 \%$ and *10\%. Number of observations: 10,129 
Table 3.a. Country-specific estimates of the pension-savings offset: Quantile and IV Quantile regressions - Dependent variable: net wealth

\section{Net Wealth}

\begin{tabular}{|c|c|c|c|c|c|c|}
\hline Country & $\begin{array}{l}\mathbf{Q 1} \\
{[\mathrm{Cl}]}\end{array}$ & $\begin{array}{c}\text { Median } \\
{[\mathrm{Cl}]} \\
\end{array}$ & $\begin{array}{l}\text { Q3 } \\
{[\mathrm{Cl}]}\end{array}$ & $\begin{array}{l}\text { Q1 } \\
{[\mathrm{Cl}]}\end{array}$ & $\begin{array}{c}\text { Median } \\
{[\mathrm{Cl}]} \\
\end{array}$ & $\begin{array}{l}\text { Q3 } \\
{[\mathrm{Cl}]}\end{array}$ \\
\hline Belgium & $\begin{array}{c}0.189 \\
{[-0.066 ; 0.444]}\end{array}$ & $\begin{array}{c}-0.179 \\
{[-0.761 ; 0.403]}\end{array}$ & $\begin{array}{c}-0.012 \\
{[-0.631 ; 0.607]}\end{array}$ & $\begin{array}{c}0.157 \\
{[-0.326 ; 0.316]}\end{array}$ & $\begin{array}{c}-0.629 \\
{[-1.177 ; 0.245]}\end{array}$ & $\begin{array}{c}-0.543 \\
{[-1.731 ; 0.312]}\end{array}$ \\
\hline Germany & $\begin{array}{c}0.107 \\
{[-0.009 ; 0.224]}\end{array}$ & $\begin{array}{c}0.087 \\
{[-0.761 ; 0.291]}\end{array}$ & $\begin{array}{c}0.061 \\
{[-0.229 ; 0.351]}\end{array}$ & $\begin{array}{c}0.621^{* *} \\
{[0.226 ; 0.866]}\end{array}$ & $\begin{array}{c}0.159 \\
{[-0.118 ; 0.484]}\end{array}$ & $\begin{array}{c}0.403 \\
{[-0.051 ; 0.707]}\end{array}$ \\
\hline France & $\begin{array}{c}0.178^{\star \star} \\
{[0.022 ; 0.333]}\end{array}$ & $\begin{array}{c}0.203^{\star *} \\
{[0.005 ; 0.401]}\end{array}$ & $\begin{array}{c}0.189 \\
{[-0.290 ; 0.670]}\end{array}$ & $\begin{array}{c}0.161^{\star *} \\
{[0.049 ; 0.249]}\end{array}$ & $\begin{array}{c}0.140 \\
{[-0.157 ; 0.618]}\end{array}$ & $\begin{array}{c}0.173 \\
{[-0.515 ; 0.737]}\end{array}$ \\
\hline Greece & $\begin{array}{c}0.137^{\star *} \\
{[0,037 ; 0.237]}\end{array}$ & $\begin{array}{c}-0.005 \\
{[-0.259 ; 0.248]}\end{array}$ & $\begin{array}{c}0.301 \\
{[-0.069 ; 0.671]}\end{array}$ & $\begin{array}{c}0.223 \\
{[-0.859 ; 0.796]}\end{array}$ & $\begin{array}{c}-0.232 \\
{[-2.164 ; 0.246]}\end{array}$ & $\begin{array}{c}-0.014 \\
{[-0.959 ; 1.446]}\end{array}$ \\
\hline Italy & $\begin{array}{c}0.279 \\
{[-0.103 ; 0.662]}\end{array}$ & $\begin{array}{c}0.225 \\
{[-0.349 ; 0 ; 799]}\end{array}$ & $\begin{array}{c}0.494 \\
{[-0.309 ; 1.297]}\end{array}$ & $\begin{array}{c}0.471 \\
{[0,096 ; 0.773]}\end{array}$ & $\begin{array}{c}0.377 \\
{[-0.259 ; 1.146]}\end{array}$ & $\begin{array}{c}0.494 \\
{[-0.282 ; 1.275]}\end{array}$ \\
\hline Luxembourg & $\begin{array}{c}0.357 \\
{[-0.286 ; 1.000]}\end{array}$ & $\begin{array}{c}-0.156 \\
{[-0.603 ; 0.290]}\end{array}$ & $\begin{array}{c}-0.409 \\
{[-1.774 ; 0.955]}\end{array}$ & $\begin{array}{c}0.704^{\star \star} \\
{[0.180 ; 0.956]}\end{array}$ & $\begin{array}{c}0.520 \\
{[-0.401 ; 1.104]}\end{array}$ & $\begin{array}{c}-0.054 \\
{[-1.377 ; 0.949]}\end{array}$ \\
\hline Portugal & $\begin{array}{c}-0.109 \\
{[-0.384 ; 0.165]} \\
\end{array}$ & $\begin{array}{c}-0.251 \\
{[-0.711 ; 0.208]}\end{array}$ & $\begin{array}{c}0.140 \\
{[-0.655 ; 0.935]}\end{array}$ & $\begin{array}{c}0.063 \\
{[-2.571 ; 7.353]} \\
\end{array}$ & $\begin{array}{c}2.005 \\
{[-3.841 ; 23.69]} \\
\end{array}$ & $\begin{array}{c}3.44 \\
{[-6.500 ; 18.43]} \\
\end{array}$ \\
\hline
\end{tabular}

Dependent variable: net wealth. Control variables: age, gender, education and income of the reference person, household composition (number of children, number of household members in employment), having received any substantial gifts or inheritances, having been credit constrained within the last three years, future income expectations and willingness to take financial risks. Pension wealth is adjusted by Gale's $Q$ factor. Significant at **5\%. IV quantiles regressions based on the cqiv procedure in STATA provided by Chernozhukov et al. $(2015)$. Number of observations: Belgium $(523)$, Germany $(1,238)$, France $(3,555)$, Greece (548), Italy (1,700), Luxembourg (702), Portugal $(1,863)$.

\section{Net Wealth IV}


Table 3.b. Country-specific estimates of the pension-savings offset: Quantile and IV Quantile regressions - Dependent variable: financial wealth

\section{Financial Wealth}

\begin{tabular}{|c|c|c|c|c|c|c|}
\hline Country & $\begin{array}{l}\text { Q1 } \\
{[\mathrm{Cl}]}\end{array}$ & $\begin{array}{c}\text { Median } \\
{[\mathrm{Cl}]} \\
\end{array}$ & $\begin{array}{l}\text { Q3 } \\
{[\mathrm{Cl}]}\end{array}$ & $\begin{array}{l}\text { Q1 } \\
{[\mathrm{Cl}]}\end{array}$ & $\begin{array}{c}\text { Median } \\
{[\mathrm{Cl}]}\end{array}$ & $\begin{array}{l}\text { Q3 } \\
{[\mathrm{Cl}]}\end{array}$ \\
\hline Belgium & $\begin{array}{c}0.043 \\
{[-0.031 ; 0.118]}\end{array}$ & $\begin{array}{c}0.009 \\
{[-0.083 ; 0.103]}\end{array}$ & $\begin{array}{c}0.080 \\
{[-0.156 ; 0.316]}\end{array}$ & $\begin{array}{c}-0.012 \\
{[-0.113 ; 0.038]}\end{array}$ & $\begin{array}{c}-0.016 \\
{[-0.214 ; 0.072]}\end{array}$ & $\begin{array}{c}-0.156 \\
{[-0.589 ; 0.121]}\end{array}$ \\
\hline Germany & $\begin{array}{c}0.008 \\
{[-0.024 ; 0.042]}\end{array}$ & $\begin{array}{c}0.080^{\star *} \\
{[0.035 ; 0.125]}\end{array}$ & $\begin{array}{c}0.134^{\star *} \\
{[0.014 ; 0.252]}\end{array}$ & $\begin{array}{c}0.096^{\star *} \\
{[0.006 ; 0.157]}\end{array}$ & $\begin{array}{c}0.182^{\star *} \\
{[0.102 ; 0.279]}\end{array}$ & $\begin{array}{c}0.578 \\
{[0.344 ; 0.752]}\end{array}$ \\
\hline France & $\begin{array}{c}0.002 \\
{[-0.025 ; 0.030]}\end{array}$ & $\begin{array}{c}0.013 \\
{[-0.011 ; 0.037]}\end{array}$ & $\begin{array}{c}0.027 \\
{[-0.055 ; 0.109]}\end{array}$ & $\begin{array}{c}0.222^{\star \star} \\
{[0.044 ; 0.575]}\end{array}$ & $\begin{array}{c}0.266^{* *} \\
{[0.077 ; 0.961]}\end{array}$ & $\begin{array}{c}0.544 \\
{[-0.017 ; 1.585]}\end{array}$ \\
\hline Greece & $\begin{array}{c}0.007 \\
{[-0.001 ; 0 ; 015]}\end{array}$ & $\begin{array}{c}0.015 \\
{[-0.001 ; 0.031]}\end{array}$ & $\begin{array}{c}-0.002 \\
{[-0.033 ; 0.029]}\end{array}$ & $\begin{array}{c}0.007 \\
{[-0.0002 ; 0.017]}\end{array}$ & $\begin{array}{c}0.014 \\
{[-0.010 ; 0.032]}\end{array}$ & $\begin{array}{c}0.015 \\
{[-0.029 ; 0.048]}\end{array}$ \\
\hline Italy & $\begin{array}{c}-0.005 \\
{[-0.032 ; 0.021]}\end{array}$ & $\begin{array}{c}0.060^{\star *} \\
{[0.002 ; 0.118]}\end{array}$ & $\begin{array}{c}0.105 \\
{[-0.062 ; 0.272]}\end{array}$ & $\begin{array}{c}-0.0005 \\
{[-0.042 ; 0.027]}\end{array}$ & $\begin{array}{c}0.073^{\star *} \\
{[0.002 ; 0.127]}\end{array}$ & $\begin{array}{c}0.129 \\
{[-0.006 ; 0.292]}\end{array}$ \\
\hline Luxembourg & $\begin{array}{c}0.127^{\star *} \\
{[0.064 ; 0.189]}\end{array}$ & $\begin{array}{c}0.085 \\
{[-0.037 ; 0.208]}\end{array}$ & $\begin{array}{c}-0.151 \\
{[-0.452 ; 0.150]}\end{array}$ & $\begin{array}{c}0.158^{\star *} \\
{[0.044 ; 0.207]}\end{array}$ & $\begin{array}{c}0.134 \\
{[-0.051 ; 0.332]}\end{array}$ & $\begin{array}{c}-0.392 \\
{[-0.608 ; 0.094]}\end{array}$ \\
\hline Portugal & $\begin{array}{c}0.039^{* *} \\
{[0.006 ; 0.073]}\end{array}$ & $\begin{array}{c}0.109^{* *} \\
{[0.038 ; 0.181]} \\
\end{array}$ & $\begin{array}{c}0.239^{* *} \\
{[0.088 ; 0.390]}\end{array}$ & $\begin{array}{c}0.152 \\
{[-0.462 ; 1.229]}\end{array}$ & $\begin{array}{c}-0.086 \\
{[-1.688 ; 1.643]}\end{array}$ & $\begin{array}{c}0.680 \\
{[-1.523 ; 6.231]} \\
\end{array}$ \\
\hline
\end{tabular}

Dependent variable: financial wealth. Control variables: age, gender, education and income of the reference person, household composition (number of children, number of household members in employment), having received any substantial gifts or inheritances, having been credit constrained within the last three years, future income expectations and willingness to take financial risks. Pension wealth is adjusted by Gale's $\mathrm{Q}$ factor. Significant at $* * 5 \%$. IV quantiles regressions based on the cqiv procedure in STATA provided by Chernozhukov et al. (2015). Number of observations: Belgium $(523)$, Germany $(1,238)$, France $(3,555)$, Greece (548), Italy $(1,700)$, Luxembourg $(702)$, Portugal $(1,863)$.

\section{Financial Wealth IV}


Table 4. Country-specific estimates of the pension-savings offset: housing wealth and risky financial assets

\section{Housing wealth}

\begin{tabular}{|c|c|c|c|c|c|c|c|c|}
\hline Country & $\begin{array}{c}\text { Probit } \\
\text { Marginal Ef. } \\
\text { (Std. Err.) }\end{array}$ & $\begin{array}{l}\text { IV Probit } \\
\text { Marginal Ef. } \\
\text { (Std. Err.) }\end{array}$ & $\begin{array}{c}\text { Tobit } \\
\text { Coef. } \\
\text { (Std. Err.) }\end{array}$ & $\begin{array}{l}\text { IV Tobit } \\
\text { Coef. } \\
\text { (Std. Err.) }\end{array}$ & $\begin{array}{c}\text { Probit } \\
\text { Marginal Ef. } \\
\text { (Std. Err.) }\end{array}$ & $\begin{array}{l}\text { IV Probit } \\
\text { Marginal Ef. } \\
\text { (Std. Err.) }\end{array}$ & $\begin{array}{c}\text { Tobit } \\
\text { Coef. } \\
\text { (Std. Err.) }\end{array}$ & $\begin{array}{l}\text { IV Tobit } \\
\text { Coef. } \\
\text { (Std. Err.) }\end{array}$ \\
\hline Belgium & $\begin{array}{l}-0.006 \\
(0.011)\end{array}$ & $\begin{array}{l}-0.072 \\
(0.051)\end{array}$ & $\begin{array}{l}-0.152 \\
(0.630)\end{array}$ & $\begin{array}{l}-0.034 \\
(0.058)\end{array}$ & $\begin{array}{l}-0.001 \\
(0.009)\end{array}$ & $\begin{array}{l}-0.020 \\
(0.031)\end{array}$ & $\begin{array}{c}0.023 \\
(0.310)\end{array}$ & $\begin{array}{c}-0.034 \\
(0.058)\end{array}$ \\
\hline Germany & $\begin{array}{c}-0.089 \\
(0.0089)\end{array}$ & $\begin{array}{c}-0.034 \\
(0.034)\end{array}$ & $\begin{array}{l}0.496^{\star} \\
(0.284)\end{array}$ & $\begin{array}{l}0.752^{*} \\
(0.415)\end{array}$ & $\begin{array}{c}0.016^{* * *} \\
(0.006)\end{array}$ & $\begin{array}{c}-0.004 \\
(0.028)\end{array}$ & $\begin{array}{l}-0.858 \\
(0.799)\end{array}$ & $\begin{array}{l}-1.597 \\
(1.136)\end{array}$ \\
\hline France & $\begin{array}{l}-0.002 \\
(0.004)\end{array}$ & $\begin{array}{c}-0.336^{\star * \star} \\
(0.072)\end{array}$ & $\begin{array}{c}0.567^{\star * \star} \\
(0.214)\end{array}$ & $\begin{array}{l}-0.239 \\
(0.944)\end{array}$ & $\begin{array}{c}0.004 \\
(0.006)\end{array}$ & $\begin{array}{l}-0.071 \\
(0.080)\end{array}$ & $\begin{array}{c}0.320 \\
(0.292)\end{array}$ & $\begin{array}{l}-0.396 \\
(0.697)\end{array}$ \\
\hline Greece & $\begin{array}{c}-0.011 \\
(0.023)\end{array}$ & $\begin{array}{l}-0.023 \\
(0.080)\end{array}$ & $\begin{array}{c}0.496 \\
(0.635)\end{array}$ & $\begin{array}{c}0.569 \\
(0.696)\end{array}$ & $\begin{array}{l}0.0002 \\
(0.001)\end{array}$ & $\begin{array}{c}0.079 \\
(0.127)\end{array}$ & $\begin{array}{l}-0.033 \\
(0.322)\end{array}$ & $\begin{array}{c}0.150 \\
(0.331)\end{array}$ \\
\hline Italy & $\begin{array}{l}-0.010 \\
(0.013)\end{array}$ & $\begin{array}{c}-0.014 \\
(0.052)\end{array}$ & $\begin{array}{l}-0.769 \\
(0.860)\end{array}$ & $\begin{array}{l}-0.338 \\
(0.613)\end{array}$ & $\begin{array}{l}0.0008 \\
(0.009)\end{array}$ & $\begin{array}{c}0.014 \\
(0.046)\end{array}$ & $\begin{array}{l}-0.499 \\
(0.448)\end{array}$ & $\begin{array}{l}-0.340 \\
(0.377)\end{array}$ \\
\hline Luxembourg & $\begin{array}{l}-0.006 \\
(0.004)\end{array}$ & $\begin{array}{l}-0.019 \\
(0.022)\end{array}$ & $\begin{array}{l}-1.722 \\
(1.434)\end{array}$ & $\begin{array}{l}-1.024 \\
(1.447)\end{array}$ & $\begin{array}{l}0.004^{*} \\
(0.002)\end{array}$ & $\begin{array}{l}0.020^{* *} \\
(0.009)\end{array}$ & $\begin{array}{c}-0.994 \\
(0.759)\end{array}$ & $\begin{array}{l}-0.409 \\
(0.669)\end{array}$ \\
\hline Portugal & $\begin{array}{c}-0.034^{* * *} \\
(0.012)\end{array}$ & $\begin{array}{l}-0.289 \\
(0.622)\end{array}$ & $\begin{array}{r}-0.382 \\
(0.439)\end{array}$ & $\begin{array}{c}0.703 \\
(3.377)\end{array}$ & $\begin{array}{c}0.005 \\
(0.007)\end{array}$ & $\begin{array}{c}-0.201 \\
(0.460)\end{array}$ & $\begin{array}{c}-0.034 \\
(0.265)\end{array}$ & $\begin{array}{l}-2,407 \\
(2.315)\end{array}$ \\
\hline
\end{tabular}

Dependent variable: housing wealth or risky financial assets. Control variables: age, gender, education and income of the reference person, household composition (number of children, number of household

members in employment), having received any substantial gifts or inheritances, having been credit constrained within the last three vears, future income expectations and willingness to take financial risks. Pension wealth is adjusted by Gale's Q factor. Significant at ${ }^{* * *} 1 \%, * * 5 \%$ and *10\%. Number of observations: Belgium $(523)$, Germany $(1,238)$, France $(3,555)$, Greece $(548)$, Italy $(1,700)$, Luxembourg $(702)$, Portugal $(1,863)$. 
Figure 1: Distribution of expected retirement age (\%) and country-specific normal retirement age

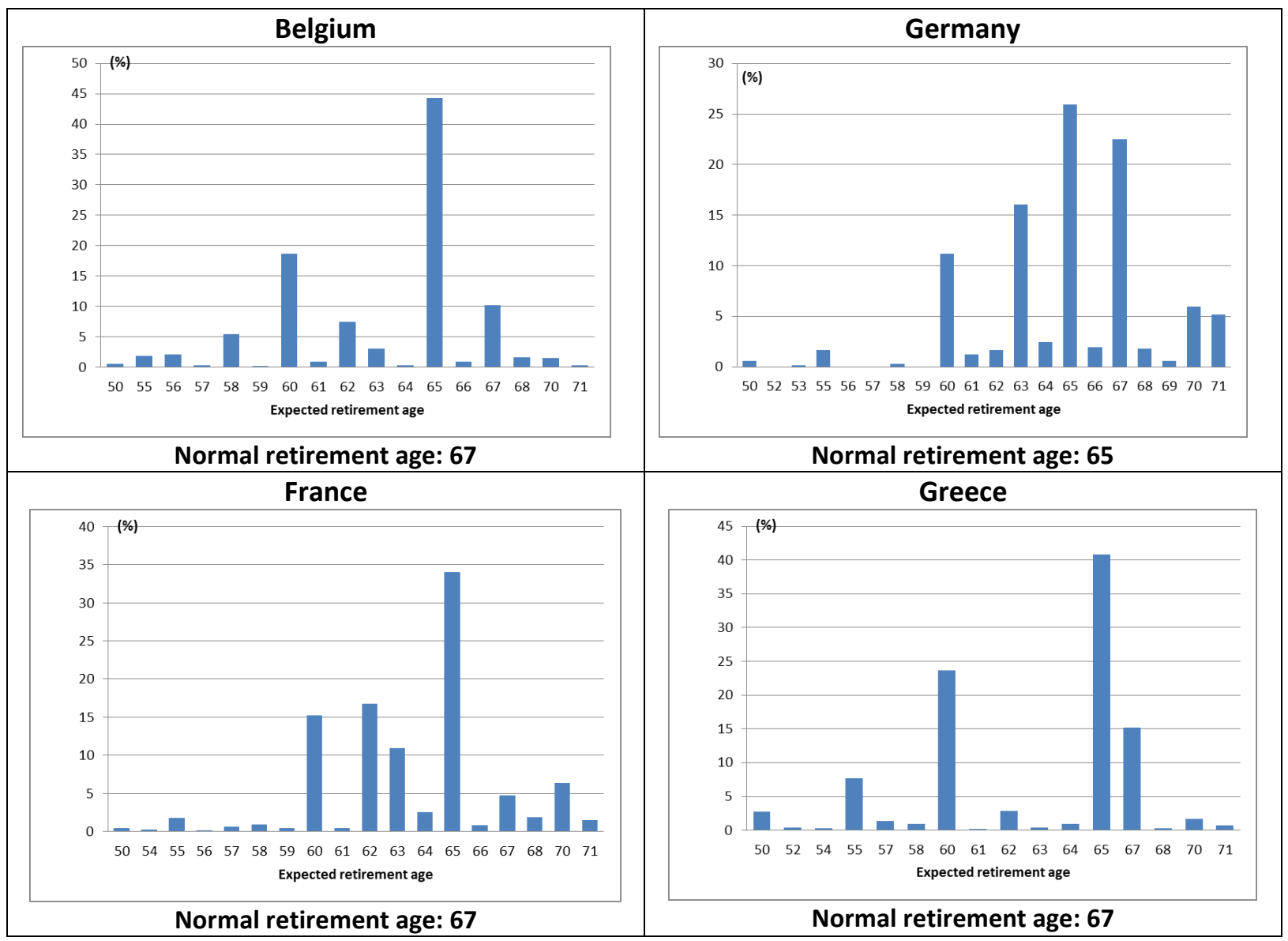


Figure 1 (continued): Distribution of expected retirement age (\%) and country-specific normal retirement age

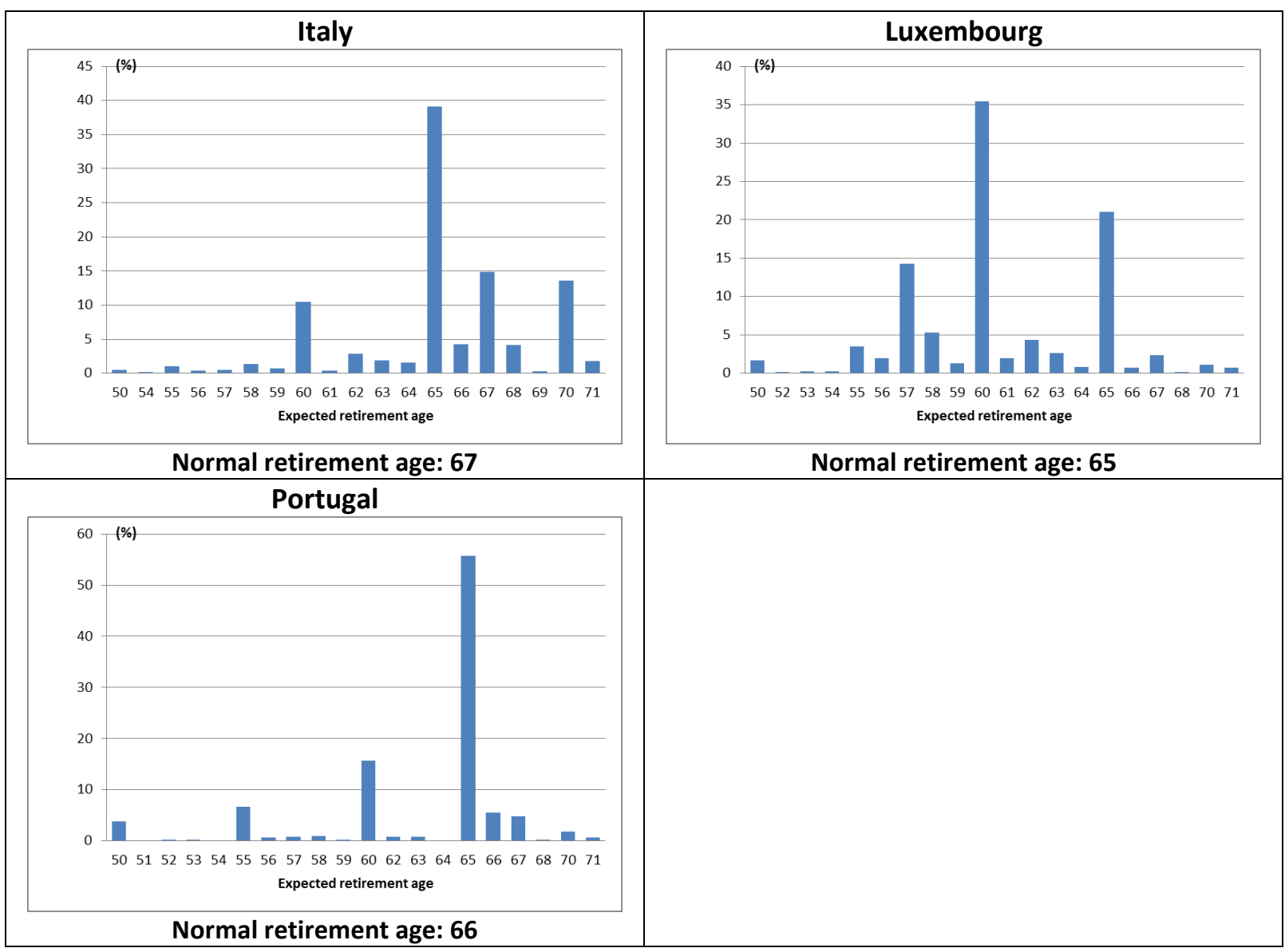

Sources: HFCS, estimation sample. Missing observations have been imputed by the Stata hot deck simulation method stratified by age, gender, education and household composition (having children or not). 
Figure 2. Pension wealth versus instrumental variable $\left(10^{4}\right.$ euro)

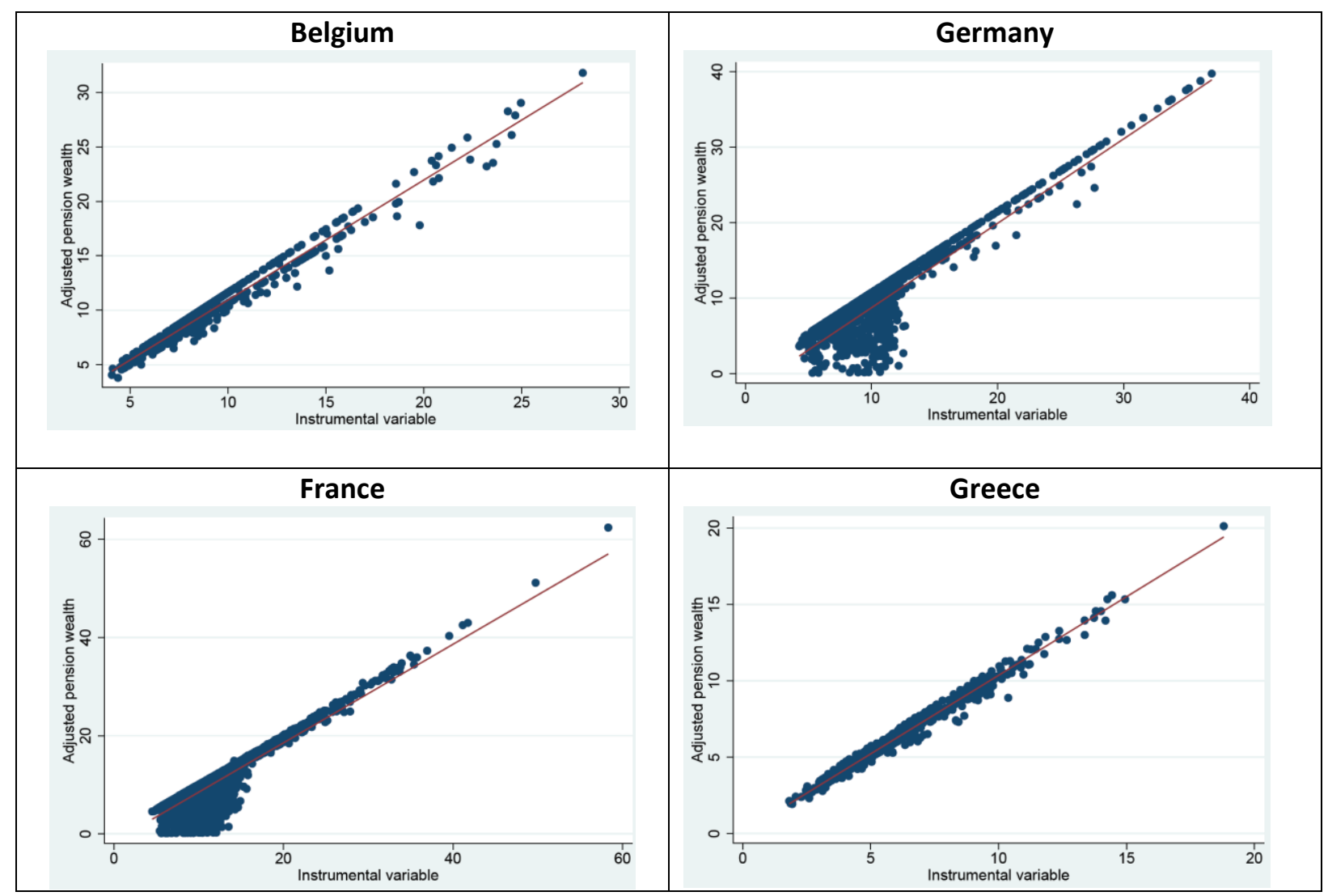


Figure 2 (continued). Pension wealth versus instrumental variable $\left(10^{4}\right.$ euro)

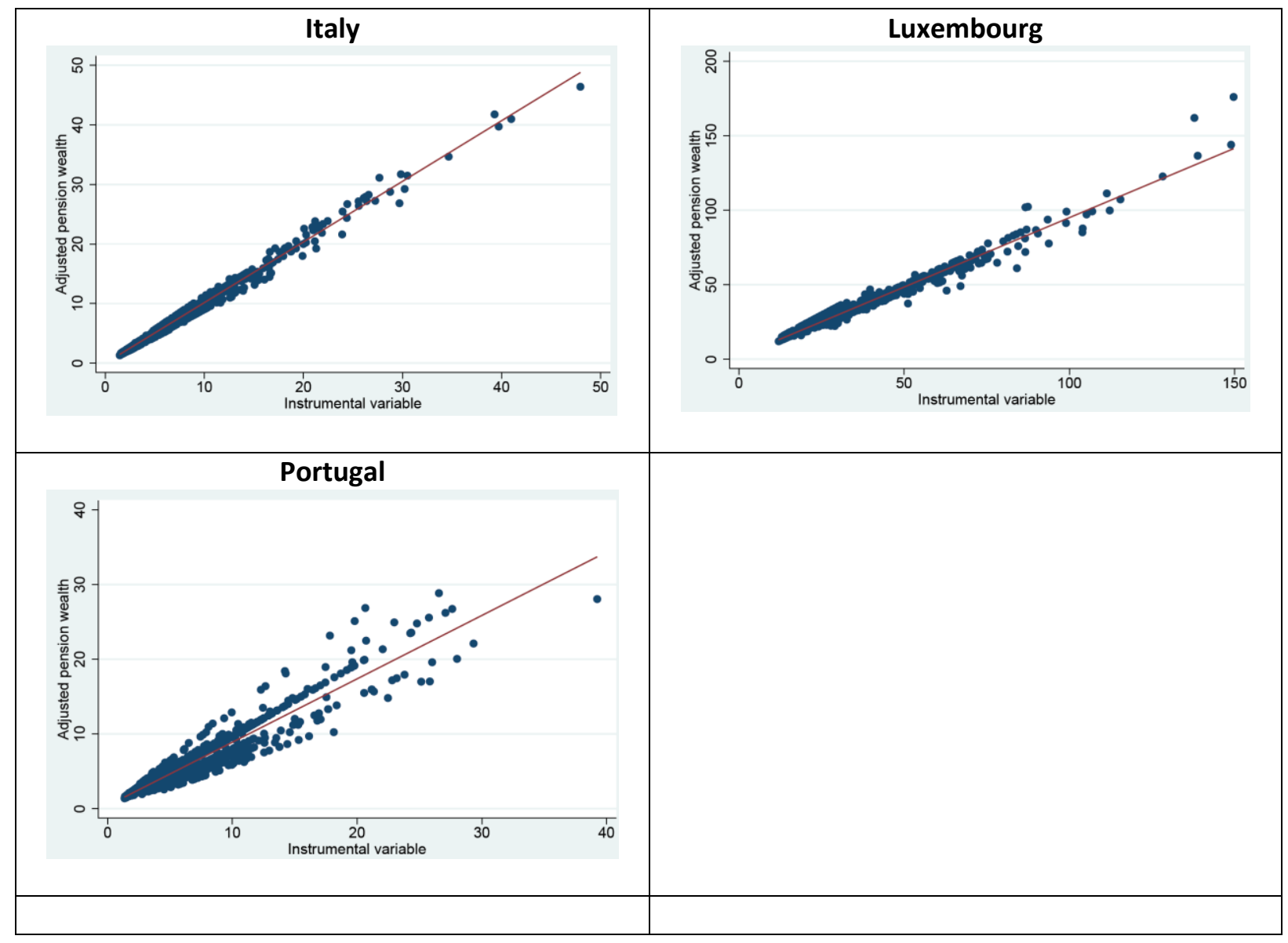

Sources: HFCS, OECD pension models, estimation sample. 
Figure 3. Non-pension wealth and adjusted pension wealth distribution by country (mean, median, Q1, Q3, P10, P90)
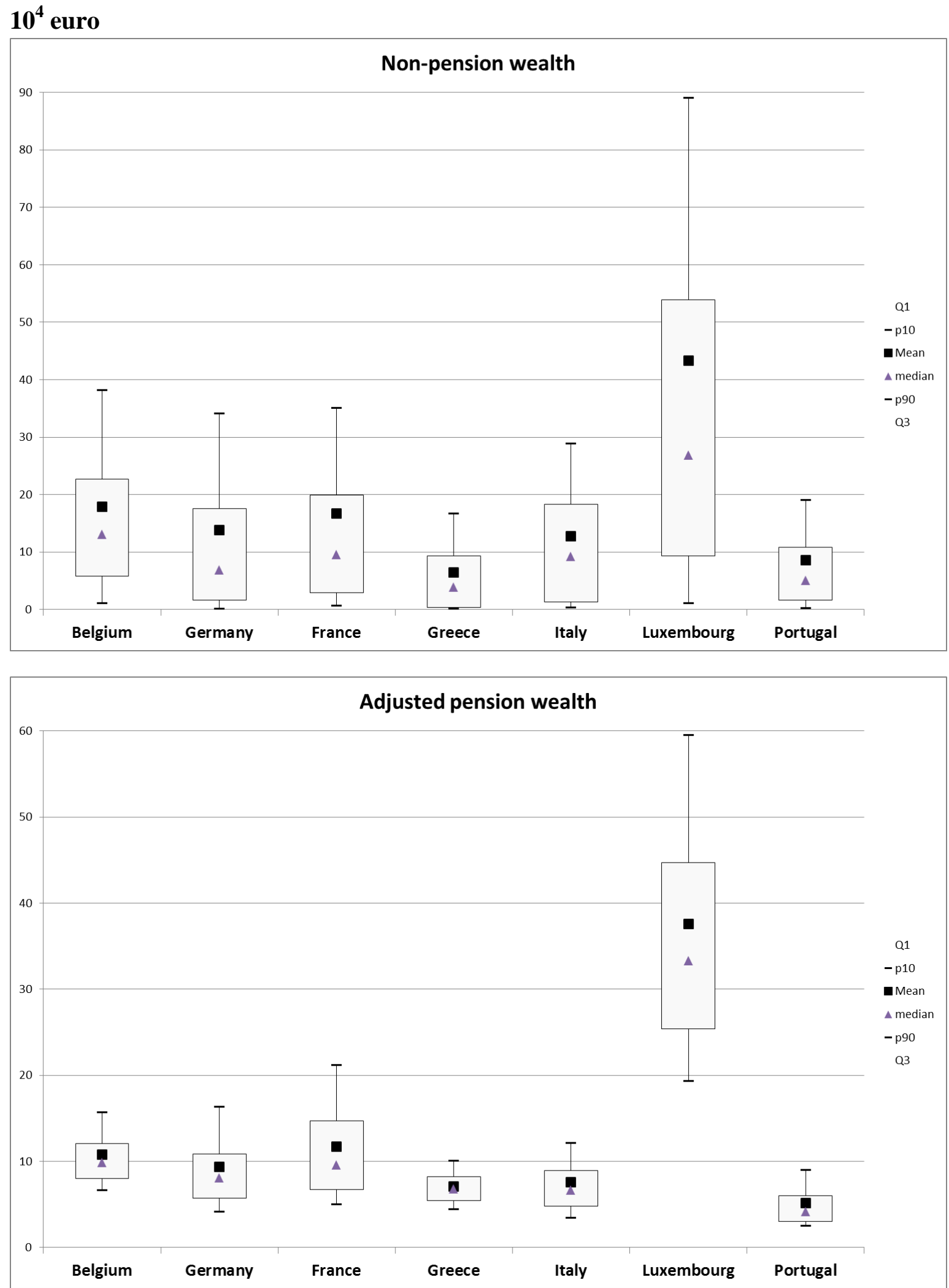

Non-pension wealth is per household members in employment. Pension wealth is adjusted by Gale's factor. Estimation sample. 


\section{APPENDIX A. BACKGROUND MODEL}

Following Alessie \& al. (2013), we derive the empirical equation from a discrete time-simple life-cycle model with no uncertainty or liquidity constraint. The within-period utility function is assumed to have constant relative risk aversion. We also assume perfect capital markets with a constant real interest rate $r$.

The consumer maximisation programme is as follows:

$$
\begin{gathered}
\max _{c_{t}} \sum_{t=1}^{T}(1+\rho)^{1-t} \frac{c_{t}^{1-\gamma}}{1-\gamma} \\
\text { s.t. } \sum_{t=1}^{T}(1+r)^{1-t} c_{t}=\sum_{t=1}^{R}(1+r)^{1-t} E_{t}+\sum_{t=R}^{T}(1+r)^{1-t} B_{t}=\sum_{t=1}^{R}(1+r)^{1-t} y_{t}
\end{gathered}
$$

With $c_{t}$ the instantaneous consumption at age $\mathrm{t}, E_{t}$ income at age $\mathrm{t}, B_{t}$ the pension benefit at age $t, R$ the retirement age, $T$ the maximum age, while $\rho$ is the discount rate and $\gamma$ the coefficient of relative risk aversion.

Wealth $W_{t}$ at a given age $\mathrm{t}$ is defined as:

$$
W_{t}=\sum_{\tau=1}^{t}(1+r)^{t-\tau}\left(y_{t}-c_{t}\right)
$$

with $\boldsymbol{y}_{\boldsymbol{t}}$ income at age $\mathrm{t}$, corresponding to wages before retirement and pension after retirement.

We set the value of the discount rate at the interest rate level, i.e. $\rho=$ r. Consumption at age $t$ is equal to:

$$
c_{t}=\left(\sum_{\tau=1}^{T}\left(\frac{1}{1+r}\right)^{\tau-1}\right)^{-1}\left(\sum_{\tau=1}^{R}(1+r)^{1-\tau} E_{t}+\sum_{\tau=R}^{T}(1+r)^{1-\tau} B_{t}\right)
$$

Substitution of (2) in (1) provides the value of wealth at age t:

$$
W_{t}=\sum_{\tau=1}^{t}(1+r)^{t-\tau} y_{t}-Q(t) \sum_{\tau=1}^{R}(1+r)^{t-\tau} E_{t}-Q(t) \sum_{\tau=R+1}^{T}(1+r)^{t-\tau} B_{t}
$$


With Q factor:

$$
Q(t)=\frac{\sum_{\tau=1}^{t}\left(\frac{1}{1+r}\right)^{\tau-1}}{\sum_{\tau=1}^{T}\left(\frac{1}{1+r}\right)^{\tau-1}}
$$

The present value of the pension benefit at age $t$ is given by $\sum_{\tau=R+1}^{T}(1+r)^{t-\tau} B_{t}$. Thus, $\mathrm{Q}(\mathrm{t}) \sum_{\tau=\mathrm{R}+1}^{\mathrm{T}}(1+\mathrm{r})^{\mathrm{t}-\tau} \mathrm{B}_{\mathrm{t}}$ is a discounted pension indicator accounting for the time individuals have had since the introduction of the pension to adjust life-time consumption. As underlined in Gale (1988), this parameter is also applicable for incomplete offset.

Considering the empirical counterpart of the components of Equation 3, we derive from the theoretical model our baseline empirical specification:

$$
\mathrm{W}_{\mathrm{i}}=\beta_{0}+\beta_{1} \mathrm{Y}_{\mathrm{i}}+\beta_{2} \mathrm{P}_{\mathrm{i}}+\gamma \mathrm{X}_{\mathrm{i}}+\delta_{\mathrm{c}}+\mathrm{u}_{\mathrm{i}}
$$

With $i$ the individual index, $W_{i}$ non-pension wealth, $Y_{i}$ income, $P_{i}$ pension wealth (mandatory pensions for the private sector) adjusted by Gale's $Q$ factor, while $X_{i}$ are additional controls, $\delta_{c}$ is the country-specific effect for country $\mathrm{c}$ and $\mathrm{u}_{\mathrm{i}}$ is the error term.

As we do not have information about earning paths, we use the additional controls to account for life-cycle patterns, differences in preferences (i.e. risk aversion, time preferences, nonhomothetic preferences), and wealth accumulation motives other than financing the retirement period (such as precautionary savings, bequest motives, etc.). 


\section{APPENDIX B: DATA}

\section{B.1. Definitions}

- Dependent variable $\left(\mathrm{W}_{\mathrm{i}}\right)$ - Source: HFCS

We consider in turn several definitions of the dependent variable.

Net (non-pension) wealth: gross wealth less liabilities at the household level- where gross wealth includes all kinds of household assets: real assets (the household's main residence, other real estate properties, vehicles, valuables) and financial assets. [variable name in the HFCS: DN3001]

Financial assets: all financial assets (excluding public and occupational pension plans) [DA2100] less the outstanding balance of non-mortgage debt [DL1200].

It includes: sight accounts, saving accounts, mutual funds, bonds, shares, managed accounts, 'other' assets, private lending, voluntary pension plans or whole life insurance contracts and non-self-employment private businesses.

Risky financial assets: sum of mutual funds [DA20102], bonds [DA2013], shares publicly traded [DA2105] and managed accounts [DA2106].

Housing wealth: sum of the value of the household's main residence [DA110] and the value of other real estate property [DA1120] less the outstanding balance of mortgage debt [DL1100].

Wealth is measured at the household level. In order to account for cross-country heterogeneity in terms of households' composition, we adjust wealth variables by the number of household members in employment [DH0004]. Wealth values are in thousands of euro.

\section{- Pension wealth $\left(P_{i}\right)$ - Source: OECD pension model}

Pension wealth is defined as the discounted sum of future pension benefits (computed at the individual's expected retirement age). It is computed using the OECD pension model (see OECD, 2015).

Pension wealth is based on the main national scheme for private-sector employees and takes account of the following characteristics of each individual in the sample: age, gender, relative 
income (compared with the average income of the same demographic group), expected retirement age and whether they have public and/or private pension plans. As retirement age is missing for some observations, ${ }^{25}$ we first perform a statistical matching procedure to impute an expected retirement age to the non-respondents (D'Orazio et al., 2006) in order to preserve the size of our estimation sample. We apply the Stata hot deck simulation method stratified by age, gender, education and household composition (having children or not).

The OECD model applies a single set of assumptions concerning the economic variables that affect pension wealth (economic growth, wage growth and inflation). These assumptions are as follows: price inflation of $2.5 \%$ per year, real earnings growth of $2 \%$ per year and a discount rate of $2 \%$ per year. In order to compute life expectancy, country-specific projections of the mortality rate by age and sex from the United Nations Population Database for the year of retirement are used. Pension wealth is computed for each country for men and women taking various multiples of average earnings and various retirement ages. It is in thousands of euro.

- Gale's $Q$

It is defined as: $Q(t)=\frac{\sum_{\tau=1}^{t}\left(\frac{1}{1+r}\right)^{\tau-1}}{\sum_{\tau=1}^{T}\left(\frac{1}{1+r}\right)^{\tau-1}}$,

With $t$ the age and $\mathrm{T}$ the maximum age according to country-specific projections of the mortality rate by age and sex from the United Nations Population Database, and with $\mathrm{r}=2 \%$.

- Income $\left(Y_{i}\right)$ - Source: HFCS

Income is measured as the gross cash employee income reported by the reference person in the HFCS [PG0110]. In this respect it is useful to note that the HFCS is a cross-sectional survey which does not allow us to construct a reliable measure of individuals' past and future earnings without making strong assumptions. For example, concerning individual careers, only information on current work income and total time in employment is available. We then introduce current gross wage income as an explanatory variable and add various control variables to capture the individual heterogeneity in life-cycle income (age and education of

\footnotetext{
${ }^{25}$ This is particularly the case for France because the question was put only to a representative sub-sample of the full HFCS sample.
} 
the reference person, number of household members in employment, household size and inheritance received). It is measured in thousands of euro.

- Other control variables $\left(X_{i}\right)$ - Source: HFCS

Demographic variables: age (divided into five groups) and education of the reference person, number of household members, number of household members in employment, number of children defined in four categories to allow for non-linear effects $(0,1,2,3$ and more), gender and education of the reference person.

Willingness to take risks: Investment attitudes are elicited in the survey by asking the following qualitative question: ${ }^{26}$ "Which of the following statements comes closest to describing the amount of financial risk that you (and your husband/wife/partner) are willing to take when you save or make investments?" [HD1800]

\section{1- Take substantial financial risks expecting to earn substantial returns}

2 - Take above average financial risks expecting to earn above average returns

3 - Take average financial risks expecting to earn average returns

4 - Not willing to take any financial risk"

We take the category "not willing to take any financial risk" as the reference group (4) which represents $72 \%$ of the sample. We group people answering that they take substantial (1) or above average financial risk (2) into one category (they add up to less than 5\% of the sample - see Table B2).

Gifts and inheritances received: Intergenerational transfers are taken into account with a dummy variable (Yes/No). It is built from the answers to two questions: one about how the main residence was acquired ${ }^{27}$ [HB0600], and the other asking about any other inheritance or substantial gift received [HH0100].

Credit constrained households: The credit constraint indicator also accounts for discouraged borrowers. Credit constrained households are defined as those that have applied for credit and been turned down or have applied for credit and were not given as much as applied for, or have not applied for credit due to perceived credit constraint.

\footnotetext{
${ }^{26}$ Dohmen et al. (2011) show that this question helps to predict financial behaviours.

27 "Did you purchase it, did you construct it yourself, did you inherit it or did you receive it as a gift?"
} 
Future income expectations: They are measured with dummy variables built from the following question: "Over the next year, do you expect your (household's) total income to go up more than prices, less than prices, or about the same as prices?" [HG0800]. The reference group is that answering "about the same as prices".

\section{B.2. Estimation procedures}

Some country-specific sub-samples of the Household Finance and Consumption Survey (HFCS) are multiply imputed (See Rubin, 1996). This is however not the case for two countries of our sample (Italy and France). When conducting the regressions on the pooled sample of countries, we thus decide to use only the first set of imputations for all countries.

The instrumented quantile regressions are performed using the cqiv procedure in STATA provided by Chernozhukov et al. (2015). This procedure employs a bootstrap procedure to estimate the standard errors (we use 50 replications). As we conduct quantile regressions which are country-specific, we apply the cqiv procedure to the five replications from the multiply-imputed dataset when available. 
Table B1.a. Structure of retirement income provision by country (Source: OECD, 2015, Table 5.2)

\begin{tabular}{|c|c|c|c|c|c|}
\hline & \multicolumn{3}{|c|}{ Tier 1} & \multicolumn{2}{|c|}{ Tier 2} \\
\hline & \multicolumn{3}{|c|}{ Public } & \multirow{2}{*}{$\begin{array}{c}\text { Public } \\
\text { Type }\end{array}$} & \multirow[t]{2}{*}{ Private } \\
\hline & Basic & Minimum & Social assistance & & \\
\hline Belgium & & $\checkmark$ & $\checkmark$ & DB & \\
\hline France & & $\checkmark$ & & $\mathrm{DB}+$ Points & \\
\hline Germany & & & $\checkmark$ & Points & \\
\hline Greece & $\checkmark$ & & & DB & \\
\hline Italy & & $\checkmark$ & & NDC & \\
\hline Luxembourg & $\checkmark$ & $\checkmark$ & & $\mathrm{DB}$ & \\
\hline Portugal & & $\checkmark$ & & DB & \\
\hline Spain & & $\checkmark$ & $\square$ & DB & \\
\hline
\end{tabular}

$\mathrm{DB}=$ Defined benefit; NDC $=$ Notional accounts.

Source: OECD (2015)

Table B1.b. Pension benefits (Tier 1) and coverage by country

\begin{tabular}{|c|c|c|c|c|c|c|c|c|}
\hline \multirow[b]{3}{*}{ Belgium } & \multicolumn{3}{|c|}{$\begin{array}{c}\text { Relative benefit value } \\
\text { (\% of earnings for average worker) }\end{array}$} & \multicolumn{3}{|c|}{$\begin{array}{l}\text { Absolute value } \\
\text { (euro per year) }\end{array}$} & \multicolumn{2}{|c|}{$\begin{array}{c}\text { Recipents } \\
\text { (\% of over } 65 \text { s receiving) }\end{array}$} \\
\hline & Basic & Minimum & $\begin{array}{c}\text { Social } \\
\text { assistance }\end{array}$ & Basic & Minimum & $\begin{array}{c}\text { Social } \\
\text { assistance }\end{array}$ & Safety-net & Minimum \\
\hline & $x$ & 29 & 26.1 & $x$ & 13,480 & 12,140 & 5 & 11 \\
\hline France & $x$ & 22 & 25.6 & $x$ & 8,248 & 9,600 & 4 & 37 \\
\hline Germany & $x$ & $x$ & 19 & $x$ & $x$ & 8,724 & 2 & $x$ \\
\hline Greece & 29 & $x$ & $x$ & 5,842 & $x$ & $x$ & 19 & $x$ \\
\hline Italy & $x$ & 21.4 & 19.1 & $x$ & 6,511 & 5,825 & 5 & 32 \\
\hline Luxembourg & 11.3 & 37.8 & 29.6 & 6,168 & 20,628 & 16,176 & 1 & 29 \\
\hline Portugal & & 30.4 & 17.4 & $\mathrm{x}$ & 5,307 & 3,039 & 17 & 59 \\
\hline
\end{tabular}

Source: OECD (2015). 
Table B1.c. Parameters and rules of mandatory income replacement pension schemes used by OECD pension models (Source OECD, 2015, Table 5.6)

\begin{tabular}{|c|c|c|c|c|c|c|}
\hline & \multicolumn{5}{|c|}{ Earnings-related schemes } & \multirow{2}{*}{$\begin{array}{c}\begin{array}{c}\text { Ceilings on } \\
\text { pensionable earnings } \\
\text { (\% of ave. earnings) }\end{array} \\
\text { Public }\end{array}$} \\
\hline & Type & $\begin{array}{c}\text { Accrual rate } \\
(\%)\end{array}$ & $\begin{array}{l}\text { Earnings } \\
\text { measure }\end{array}$ & Valorisation & Indexation & \\
\hline Belgium & DB & 1.33 & $\mathrm{~L}$ & $\mathrm{p}$ & $\mathrm{p}$ & 114 \\
\hline France & DB/points & 1.06 & $\mathrm{~b} 25 / \mathrm{L}$ & $\mathrm{p} / \mathrm{p}$ & $\mathrm{p} / \mathrm{p}$ & $100 / 284(1)$ \\
\hline Germany & Points & 1.00 & $\mathrm{~L}$ & $\mathrm{w}[\mathrm{c}]$ & w [c] & 151 \\
\hline Greece & DB & $0.8-1.5$ & $\mathrm{~L}$ & $\mathrm{p}$ & 50p/50GDP & $379(2)$ \\
\hline Italy & NDC & 1.46 & $\mathrm{~L}$ & GDP & $\mathrm{p}(3)$ & 328 \\
\hline Luxembourg & DB & $1.92[\mathrm{y}]$ & $\mathrm{L}$ & w & $\mathrm{p} / \mathrm{w}$ & 174 \\
\hline Portugal & DB & $2.3-2[w]$ & $\mathrm{L}$ & $25 w / 75 p$ & p/GDP (4) & None \\
\hline
\end{tabular}

Note: Parameters are for 2014 and include all legislated changes that take effect in the future.

$\mathrm{b}=$ Number of best years; $\mathrm{f}=$ Number of final years; $[\mathrm{c}]=$ Valorisation/indexation conditional on financial sustainability; DB

$=$ Defined benefit $;$ GDP $=$ Growth of gross domestic product $; \mathrm{L}=$ Lifetime average; NDC $=$ Notional accounts; $\mathrm{p}=$

Valorisation/indexation with prices; $\mathrm{w}=$ Valorisation/indexation with average earnings; $[\mathrm{w}]=$ Varies with earnings; $[\mathrm{y}]=$ Varies with years of service.

(1) France: the first ceiling relates to the national pension scheme, the second to the main mandatory occupational plan (ARRCO).

(2) Greece: effective ceiling calculated from maximum pension.

(3) Italy: indexation is fully to prices for low pensions and $75 \%$ of prices for higher pensions.

(4) Portugal: indexation will be higher relative to prices for low pensions and vice versa. Indexation will be more generous the higher GDP growth is. 
Table B2. Sample statistics: non-pension wealth and pension wealth variables

\begin{tabular}{|c|c|c|c|c|c|c|c|c|c|c|c|c|c|c|}
\hline & \multicolumn{2}{|c|}{ Belgium } & \multicolumn{2}{|c|}{ Germany } & \multicolumn{2}{|c|}{ France } & \multicolumn{2}{|c|}{ Greece } & \multicolumn{2}{|c|}{ Italy } & \multicolumn{2}{|c|}{ Luxembourg } & \multicolumn{2}{|c|}{ Portugal } \\
\hline & Mean & Std. Dev. & Mean & Std. Dev. & Mean & Std. Dev. & Mean & Std. Dev. & Mean & Std. Dev. & Mean & Std. Dev. & Mean & Std. Dev. \\
\hline Non-pension wealth & 17.92 & 20.63 & 13.86 & 22.78 & 16.75 & 40.16 & 6.42 & 9.42 & 12.70 & 19.44 & 43.32 & 136.43 & 8.63 & 13.31 \\
\hline Financial wealth & 4.75 & 9.98 & 4.15 & 10.02 & 3.96 & 31.17 & 0.49 & 2.40 & 1.35 & 7.18 & 10.94 & 98.96 & 1.49 & 4.95 \\
\hline \multicolumn{15}{|l|}{ Own real estate } \\
\hline property (Yes/No) & 0.79 & 0.41 & 0.63 & 0.48 & 0.73 & 0.44 & 0.62 & 0.49 & 0.69 & 0.46 & 0.82 & 0.38 & 0.86 & 0.34 \\
\hline Housing wealth & 12.51 & 14.49 & 9.03 & 17.14 & 11.22 & 17.54 & 5.49 & 8.49 & 10.59 & 14.89 & 30.70 & 45.90 & 6.51 & 10.51 \\
\hline \multicolumn{15}{|l|}{ Hold Risky financial } \\
\hline assets (Yes/No) & 0.33 & 0.47 & 0.33 & 0.47 & 0.33 & 0.47 & 0.03 & 0.16 & 0.18 & 0.39 & 0.25 & 0.44 & 0.11 & 0.31 \\
\hline Risk financial wealth & 1.58 & 6.25 & 0.95 & 7.81 & 0.89 & 8.75 & 0.04 & 0.46 & 0.55 & 3.37 & 2.59 & 18.84 & 0.14 & 1.19 \\
\hline \multicolumn{15}{|l|}{ Adjusted Pension } \\
\hline $\begin{array}{l}\text { wealth } \\
\text { Adjusted Pension } \\
\text { wealth with normal } \\
\text { retirement age }\end{array}$ & 10.52 & 4.16 & 9.22 & 5.75 & 9.87 & 5.23 & 6.43 & 2.33 & 6.86 & 4.33 & 37.33 & 18.92 & 5.15 & 3.57 \\
\hline (instrument) & 9.62 & 3.73 & 10.42 & 4.67 & 11.37 & 4.61 & 6.18 & 2.25 & 6.75 & 4.23 & 38.04 & 19.96 & 5.58 & 4.02 \\
\hline Number of individuals & \multicolumn{2}{|c|}{523} & \multicolumn{2}{|c|}{1,238} & \multicolumn{2}{|c|}{3,555} & \multicolumn{2}{|c|}{548} & \multicolumn{2}{|c|}{1,700} & \multicolumn{2}{|c|}{702} & \multicolumn{2}{|c|}{1,863} \\
\hline
\end{tabular}

Wealth is measured at the household level. All quantitative wealth variables are in thousands of euro. Pension wealth is computed for the household reference person. Non-pension wealth variables are per number of household members in employment. Units: $10^{4}$ Euro. 
Table B3. Sample statistics: control variables

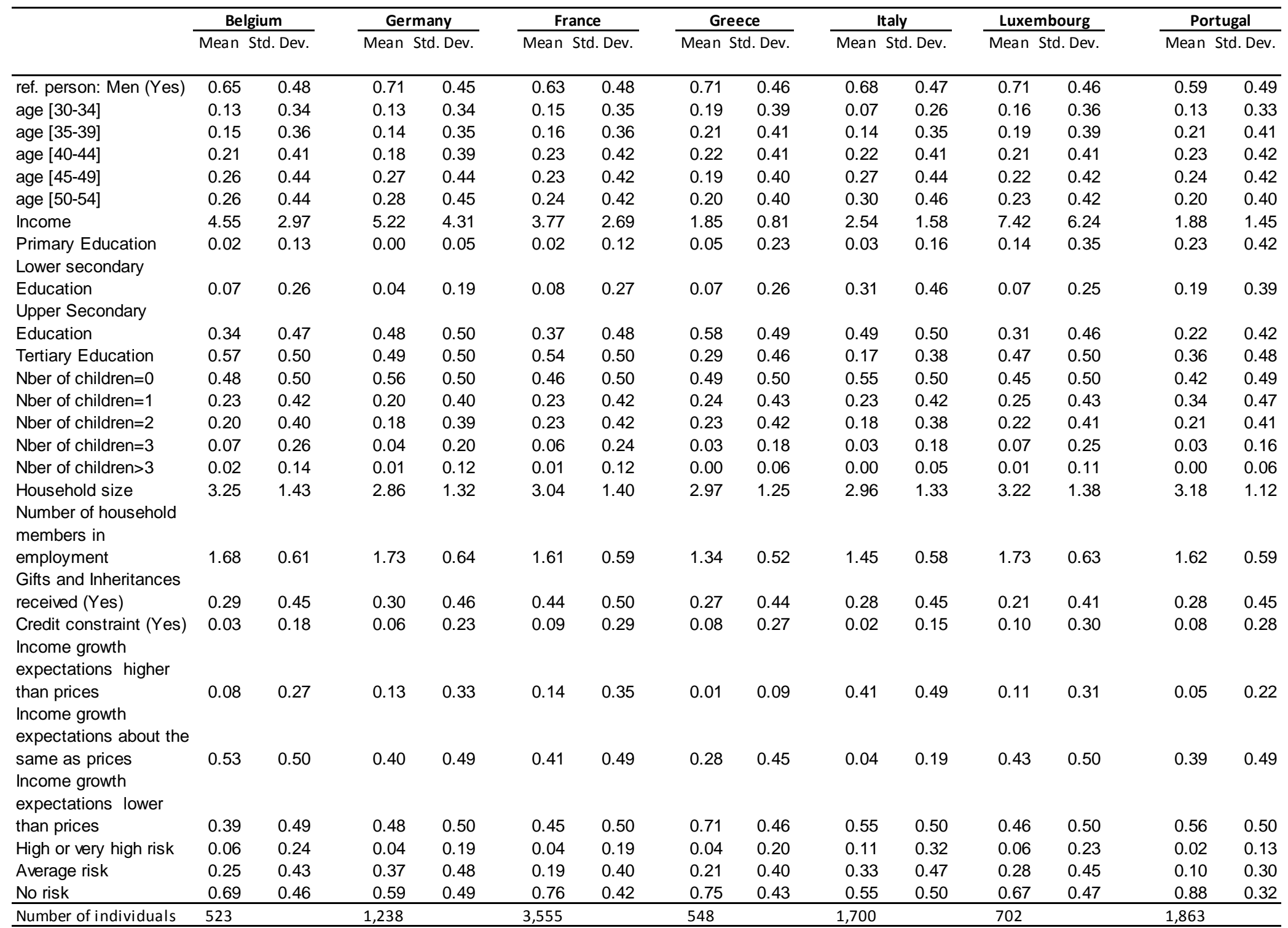




\section{APPENDIX C: ADDITIONAL RESULTS}

\section{C.1. First stage estimates - Dependent variable: pension wealth}

\begin{tabular}{|c|c|c|}
\hline \multirow[t]{2}{*}{ Dependent variable } & \multicolumn{2}{|c|}{ Pension wealth } \\
\hline & Coef. & Std. Err. \\
\hline Pension wealth with normal retirement age & $0.749^{\star \star \star}$ & 0.005 \\
\hline men (Yes) & 0.069 * & 0.037 \\
\hline age [30-34] & ref. & \\
\hline age [35-39] & -0.037 & 0.062 \\
\hline age [40-44] & -0.088 & 0.060 \\
\hline age [45-49] & $-0.116 *$ & 0.061 \\
\hline age $[50-54]$ & $-0.369 * * *$ & 0.065 \\
\hline Income & $0.806^{* * *}$ & 0.019 \\
\hline Income ${ }^{2}$ & $-0.018^{* * *}$ & 0.001 \\
\hline Income ${ }^{\wedge} 3$ & $0.000^{* * *}$ & 0.000 \\
\hline Primary Education & ref. & \\
\hline Lower secondary Education & $-0.765^{* \star *}$ & 0.083 \\
\hline Upper Secondary Education & $-0.805^{* \star *}$ & 0.076 \\
\hline Tertiary Education & $-0.440^{* * *}$ & 0.080 \\
\hline Nber of children $=0$ & ref. & \\
\hline Nber of children=1 & $-0.084 *$ & 0.049 \\
\hline Nber of children=2 & -0.089 & 0.064 \\
\hline Nber of children=3 & -0.154 & 0.107 \\
\hline Nber of children>3 & -0.228 & 0.198 \\
\hline Household size & $0.079 * * *$ & 0.023 \\
\hline Number of household members in employment & $-0.075^{* *}$ & 0.033 \\
\hline Gifts and Inheritances received (Yes) & $-0.060 *$ & 0.036 \\
\hline Credit constraint (Yes) & -0.033 & 0.066 \\
\hline Income growth expectations higher than prices & 0.099 * & 0.055 \\
\hline Income growth expectations about the same as prices & ref. & \\
\hline Income growth expectations lower than prices & 0.047 & 0.038 \\
\hline High or very high risk & ref. & \\
\hline Average risk & 0.007 & 0.080 \\
\hline no risk & 0.055 & 0.042 \\
\hline Belgium & $-3.850^{* * *}$ & 0.150 \\
\hline Germany & $-6.023^{* * *}$ & 0.142 \\
\hline France & $-5.249 * * *$ & 0.122 \\
\hline Greece & $-3.506 * * *$ & 0.146 \\
\hline Italy & $-3.925 * * *$ & 0.139 \\
\hline Luxembourg & ref. & \\
\hline Portugal & $-4.531^{* * *}$ & 0.135 \\
\hline constant & $4.545^{* * *}$ & 0.157 \\
\hline Number of observations & 10,129 & \\
\hline Adjusted $R^{2}$ & 0.97 & \\
\hline$F(30,10098)$ & 12,348 & \\
\hline
\end{tabular}

Dependent variable: pension wealth (adjusted by the $Q$ factor), computed using national mandatory pension schemes by age, gender, income (as a percentage of the average income of the same demographic group) and individual expectations about retirement age (provided by the HFCS survey). The instrument "Pension wealth with normal retirement age" is based on the normal retirement age for the country. 


\begin{tabular}{|c|c|c|c|c|}
\hline & \multicolumn{2}{|c|}{$\begin{array}{l}\text { Net wealth } \\
\text { (1) }\end{array}$} & \multicolumn{2}{|c|}{$\begin{array}{c}\text { Financial wealth } \\
\text { (2) }\end{array}$} \\
\hline & OLS & IV & OLS & IV \\
\hline & $\begin{array}{l}\text { Coef. } \\
\text { (Std. Err.) }\end{array}$ & $\begin{array}{c}\text { Coef. } \\
\text { (Std. Err.) }\end{array}$ & $\begin{array}{c}\text { Coef. } \\
\text { (Std. Err.) }\end{array}$ & $\begin{array}{c}\text { Coef. } \\
\text { (Std. Err.) }\end{array}$ \\
\hline Pension wealth & $\begin{array}{c}-0.595^{\star \star \star} \\
(0.131)\end{array}$ & $\begin{array}{l}-0.227 \\
(0.155)\end{array}$ & $\begin{array}{l}-0.699^{\star \star \star} \\
(0.0969)\end{array}$ & $\begin{array}{c}-0.531^{\star \star \star} \\
(0.115)\end{array}$ \\
\hline men (Yes) & $\begin{array}{c}1.434 \\
(0.899)\end{array}$ & $\begin{array}{l}1.366 \\
(0.898)\end{array}$ & $\begin{array}{l}1.704^{\star *} \\
(0.667)\end{array}$ & $\begin{array}{l}1.673^{\star *} \\
(0.666)\end{array}$ \\
\hline age [30-34] & ref. & ref. & ref. & ref. \\
\hline age [35-39] & $\begin{array}{l}1.627 \\
(1.514)\end{array}$ & $\begin{array}{c}1.403 \\
(1.513)\end{array}$ & $\begin{array}{c}1.130 \\
(1.123)\end{array}$ & $\begin{array}{c}1.028 \\
(1.123)\end{array}$ \\
\hline age [40-44] & $\begin{array}{c}5.237^{\star * *} \\
(1.450)\end{array}$ & $\begin{array}{c}4.779^{\star * *} \\
(1.452)\end{array}$ & $\begin{array}{l}2.335^{* *} \\
(1.076)\end{array}$ & $\begin{array}{l}2.125^{\star \star} \\
(1.077)\end{array}$ \\
\hline age [45-49] & $\begin{array}{c}9.656^{\star \star *} \\
(1.475)\end{array}$ & $\begin{array}{c}8.981^{* * *} \\
(1.481)\end{array}$ & $\begin{array}{c}4.629^{* \star *} \\
(1.094)\end{array}$ & $\begin{array}{c}4.320^{\star * *} \\
(1.099)\end{array}$ \\
\hline age [50-54] & $\begin{array}{c}12.27^{\star * *} \\
(1.547)\end{array}$ & $\begin{array}{l}11.38^{\star * \star} \\
(1.558)\end{array}$ & $\begin{array}{c}5.460^{\star * *} \\
(1.148)\end{array}$ & $\begin{array}{c}5.054^{\star \star \star} \\
(1.156)\end{array}$ \\
\hline Income & $\begin{array}{l}0.283 \\
(0.508)\end{array}$ & $\begin{array}{l}-0.554 \\
(0.542)\end{array}$ & $\begin{array}{l}-0.915^{\star *} \\
(0.377)\end{array}$ & $\begin{array}{c}-1.299^{* * *} \\
(0.402)\end{array}$ \\
\hline Income $^{2}$ & $\begin{array}{l}0.227^{\star \star \star} \\
(0.0254)\end{array}$ & $\begin{array}{l}0.233^{* * *} \\
(0.0254)\end{array}$ & $\begin{array}{l}0.202^{* * *} \\
(0.0189)\end{array}$ & $\begin{array}{l}0.205^{\star \star \star} \\
(0.0189)\end{array}$ \\
\hline Income ${ }^{\wedge}$ & $\begin{array}{l}-0.000792^{* *} \\
(0.000323)\end{array}$ & $\begin{array}{l}-0.000845^{\star \star \star} \\
(0.000322)\end{array}$ & $\begin{array}{l}-0.000846^{* \star *} \\
(0.000239)\end{array}$ & $\begin{array}{l}-0.000871^{* \star *} \\
(0.000239)\end{array}$ \\
\hline Primary Education & ref. & ref. & ref. & ref. \\
\hline Lower secondary Education & $\begin{array}{l}2.377 \\
(2.012)\end{array}$ & $\begin{array}{l}2.284 \\
(2.009)\end{array}$ & $\begin{array}{c}1.052 \\
(1.493)\end{array}$ & $\begin{array}{c}1.009 \\
(1.491)\end{array}$ \\
\hline Upper Secondary Education & $\begin{array}{c}6.209^{\star * *} \\
(1.851)\end{array}$ & $\begin{array}{c}6.026^{\star \star *} \\
(1.850)\end{array}$ & $\begin{array}{l}2.256 \\
(1.374)\end{array}$ & $\begin{array}{l}2.172 \\
(1.372)\end{array}$ \\
\hline Tertiary Education & $\begin{array}{c}10.89^{\star \star *} \\
(1.948)\end{array}$ & $\begin{array}{c}10.75^{\star \star \star} \\
(1.946)\end{array}$ & $\begin{array}{c}5.664^{* * *} \\
(1.445)\end{array}$ & $\begin{array}{c}5.597^{* * *} \\
(1.444)\end{array}$ \\
\hline Nber of children $=0$ & ref. & ref. & ref. & ref. \\
\hline Nber of children=1 & $\begin{array}{l}-1.547 \\
(1.202)\end{array}$ & $\begin{array}{l}-1.518 \\
(1.200)\end{array}$ & $\begin{array}{l}-0.252 \\
(0.892)\end{array}$ & $\begin{array}{c}-0.239 \\
(0.891)\end{array}$ \\
\hline Nber of children=2 & $\begin{array}{l}-1.489 \\
(1.560)\end{array}$ & $\begin{array}{l}-1.469 \\
(1.558)\end{array}$ & $\begin{array}{c}0.570 \\
(1.158)\end{array}$ & $\begin{array}{c}0.579 \\
(1.156)\end{array}$ \\
\hline Nber of children=3 & $\begin{array}{l}-5.118^{\star \star} \\
(2.602)\end{array}$ & $\begin{array}{l}-5.140^{* *} \\
(2.599)\end{array}$ & $\begin{array}{l}-0.556 \\
(1.931)\end{array}$ & $\begin{array}{l}-0.566 \\
(1.929)\end{array}$ \\
\hline Nber of children>3 & $\begin{array}{l}-11.03^{* *} \\
(4.812)\end{array}$ & $\begin{array}{c}-10.69^{\star *} \\
(4.807)\end{array}$ & $\begin{array}{c}-4.100 \\
(3.571)\end{array}$ & $\begin{array}{l}-3.943 \\
(3.567)\end{array}$ \\
\hline
\end{tabular}




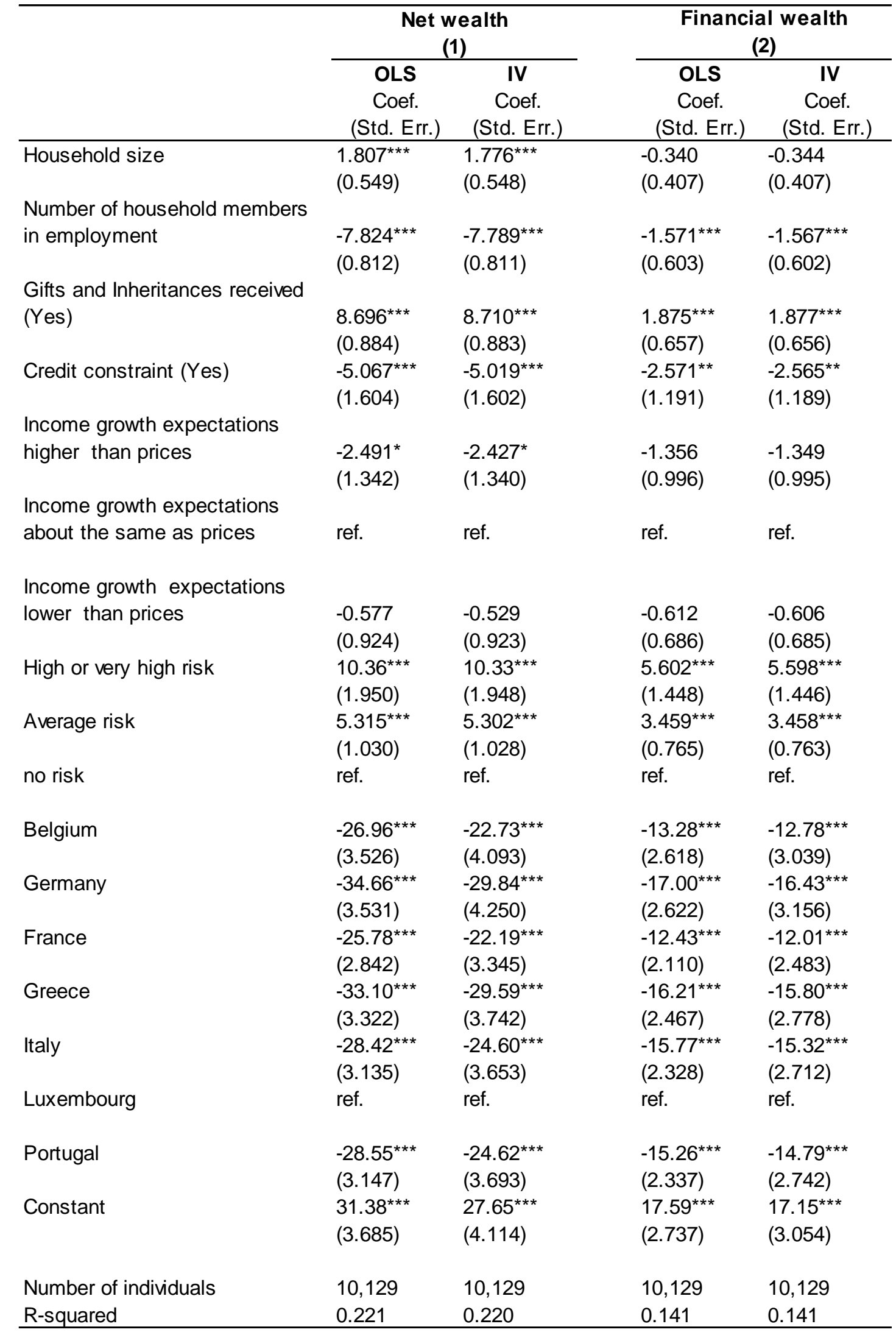


Table C.3. Estimates of the pension-savings offset: heterogeneity across educational levels

\begin{tabular}{|c|c|c|c|c|c|c|c|c|c|c|c|c|}
\hline & \multicolumn{2}{|c|}{ Net wealth } & \multicolumn{2}{|c|}{ Financial wealth } & \multicolumn{4}{|c|}{ Housing wealth } & \multicolumn{4}{|c|}{ Risky financial assets } \\
\hline & OLS & IV & OLS & IV & Probit & IV Probit & Tobit & IV Tobit & Probit & IV Probit & Tobit & IV Tobit \\
\hline Pension wealth & $\begin{array}{c}-0.710^{* * *} \\
(0.228)\end{array}$ & $\begin{array}{l}-0.331 \\
(0.253)\end{array}$ & $\begin{array}{c}-0.739^{\star * *} \\
(0.169)\end{array}$ & $\begin{array}{c}-0.624^{\star * *} \\
(0.188)\end{array}$ & $\begin{array}{c}0.001 \\
(0.003)\end{array}$ & $\begin{array}{l}-0.0004 \\
(0.011)\end{array}$ & $\begin{array}{l}-0.107 \\
(0.120)\end{array}$ & $\begin{array}{l}0.0466 \\
(0.132)\end{array}$ & $\begin{array}{l}0.006^{\star *} \\
(0.003)\end{array}$ & $\begin{array}{l}0.022^{*} \\
(0.011)\end{array}$ & $\begin{array}{c}-0.0768 \\
(0.155)\end{array}$ & $\begin{array}{l}-0.0781 \\
(0.163)\end{array}$ \\
\hline $\begin{array}{l}\text { Pension wealth*Lower } \\
\text { secondary education }\end{array}$ & $\begin{array}{r}-0.0604 \\
(0.256)\end{array}$ & $\begin{array}{l}-0.173 \\
(0.266)\end{array}$ & $\begin{array}{c}-0.00275 \\
(0.190)\end{array}$ & $\begin{array}{r}-0.0512 \\
(0.198)\end{array}$ & $\begin{array}{c}-0.009^{* * *} \\
(0.003)\end{array}$ & $\begin{array}{l}-0.040^{* * *} \\
(0.010)\end{array}$ & $\begin{array}{l}-0.151 \\
(0.137)\end{array}$ & $\begin{array}{l}-0.249^{*} \\
(0.143)\end{array}$ & $\begin{array}{l}0.0007 \\
(0.003)\end{array}$ & $\begin{array}{c}0,005 \\
(0.012)\end{array}$ & $\begin{array}{c}0.00386 \\
(0.173)\end{array}$ & $\begin{array}{l}0.0133 \\
(0.177)\end{array}$ \\
\hline $\begin{array}{l}\text { Pension wealth*Upper } \\
\text { secondary education }\end{array}$ & $\begin{array}{l}0.388^{*} \\
(0.198)\end{array}$ & $\begin{array}{l}0.354^{\star} \\
(0.202)\end{array}$ & $\begin{array}{l}0.0323 \\
(0.147)\end{array}$ & $\begin{array}{c}0.00665 \\
(0.150)\end{array}$ & $\begin{array}{l}-0,003 \\
(0.002)\end{array}$ & $\begin{array}{l}-0.016^{\star *} \\
(0.009)\end{array}$ & $\begin{array}{l}0.247^{\star *} \\
(0.105)\end{array}$ & $\begin{array}{l}0.238^{\star *} \\
(0.107)\end{array}$ & $\begin{array}{l}-0,006 \\
(0.002)\end{array}$ & $\begin{array}{l}-0,004 \\
(0.009)\end{array}$ & $\begin{array}{c}-0.0393 \\
(0.147)\end{array}$ & $\begin{array}{r}-0.0614 \\
(0.149)\end{array}$ \\
\hline $\begin{array}{l}\text { Pension } \\
\text { wealthTertiary } \\
\text { education } \\
\text { Primary education }\end{array}$ & $\begin{array}{c}0.101 \\
(0.190) \\
\text { ref. }\end{array}$ & $\begin{array}{c}0.112 \\
(0.194) \\
\text { ref. }\end{array}$ & $\begin{array}{c}0.0420 \\
(0.141) \\
\text { ref. }\end{array}$ & $\begin{array}{c}0.0929 \\
(0.144) \\
\text { ref. }\end{array}$ & $\begin{array}{c}-0.008^{* * *} \\
(0.002) \\
\text { ref. }\end{array}$ & $\begin{array}{c}-0.031^{\star * *} \\
(0.008) \\
\text { ref. }\end{array}$ & $\begin{array}{c}-0.0405 \\
(0.100) \\
\text { ref. }\end{array}$ & $\begin{array}{c}-0.0594 \\
(0.103) \\
\text { ref. }\end{array}$ & $\begin{array}{c}-0.004^{*} \\
(0.002) \\
\text { ref. }\end{array}$ & $\begin{array}{c}-0.015^{\star} \\
(0.009) \\
\text { ref. }\end{array}$ & $\begin{array}{c}-0.0989 \\
(0.142) \\
\text { ref. }\end{array}$ & $\begin{array}{c}-0.0853 \\
(0.144) \\
\text { ref. }\end{array}$ \\
\hline $\begin{array}{l}\text { Lower secondary } \\
\text { education }\end{array}$ & $\begin{array}{c}2.444 \\
(2.701)\end{array}$ & $\begin{array}{l}3.088 \\
(2.742)\end{array}$ & $\begin{array}{c}1.025 \\
(2.005)\end{array}$ & $\begin{array}{c}1.287 \\
(2.035)\end{array}$ & $\begin{array}{c}0.132^{\star \star *} \\
(0.027)\end{array}$ & $\begin{array}{c}0.527^{\star * *} \\
(0.100)\end{array}$ & $\begin{array}{c}2.364 \\
(1.494)\end{array}$ & $\begin{array}{l}2.908^{\star} \\
(1.512)\end{array}$ & $\begin{array}{l}0.085^{\star *} \\
(0.042)\end{array}$ & $\begin{array}{l}0.333^{\star *} \\
(0.164)\end{array}$ & $\begin{array}{l}5.092^{\star *} \\
(2.502)\end{array}$ & $\begin{array}{l}5.290^{* *} \\
(2.535)\end{array}$ \\
\hline $\begin{array}{l}\text { Upper secondary } \\
\text { education }\end{array}$ & $\begin{array}{l}2.883 \\
(2.444)\end{array}$ & $\begin{array}{l}2.973 \\
(2.469)\end{array}$ & $\begin{array}{l}2.000 \\
(1.815)\end{array}$ & $\begin{array}{l}2.166 \\
(1.833)\end{array}$ & $\begin{array}{c}0.168^{\star \star *} \\
(0.025)\end{array}$ & $\begin{array}{l}0.645^{\star \star \star} \\
(0.096)\end{array}$ & $\begin{array}{l}3.445^{\star *} \\
(1.345)\end{array}$ & $\begin{array}{l}3.385^{\star \star} \\
(1.358)\end{array}$ & $\begin{array}{c}0.137^{\star * *} \\
(0.038)\end{array}$ & $\begin{array}{c}0.571^{* * *} \\
(0.150)\end{array}$ & $\begin{array}{c}7.778^{\star \star *} \\
(2.335)\end{array}$ & $\begin{array}{c}8.263^{\star * *} \\
(2.364)\end{array}$ \\
\hline Tertiary education & $\begin{array}{c}10.38^{* * *} \\
(2.475) \\
\end{array}$ & $\begin{array}{c}10.03^{* * *} \\
(2.496) \\
\end{array}$ & $\begin{array}{c}5.306^{* * *} \\
(1.838) \\
\end{array}$ & $\begin{array}{l}4.715^{\star *} \\
(1.853) \\
\end{array}$ & $\begin{array}{c}0.244^{* * *} \\
(0.026) \\
\end{array}$ & $\begin{array}{l}0.885^{\star * *} \\
(0.096)\end{array}$ & $\begin{array}{c}7.694^{* * *} \\
(1.323) \\
\end{array}$ & $\begin{array}{c}7.692^{* * *} \\
(1.330) \\
\end{array}$ & $\begin{array}{c}0.275^{\star * *} \\
(0.037) \\
\end{array}$ & $\begin{array}{l}1.074^{* * *} \\
(0.147) \\
\end{array}$ & $\begin{array}{c}12.80^{* * *} \\
(2.301) \\
\end{array}$ & $\begin{array}{r}12.89^{* * *} \\
(2.324) \\
\end{array}$ \\
\hline $\begin{array}{l}\text { Other control variables } \\
\text { Country fixed effects }\end{array}$ & $\begin{array}{l}\text { yes } \\
\text { yes }\end{array}$ & $\begin{array}{l}\text { yes } \\
\text { yes }\end{array}$ & $\begin{array}{l}\text { yes } \\
\text { yes }\end{array}$ & $\begin{array}{l}\text { yes } \\
\text { yes }\end{array}$ & $\begin{array}{l}\text { yes } \\
\text { yes }\end{array}$ & $\begin{array}{l}\text { yes } \\
\text { yes }\end{array}$ & $\begin{array}{l}\text { yes } \\
\text { yes }\end{array}$ & $\begin{array}{l}\text { yes } \\
\text { yes }\end{array}$ & $\begin{array}{l}\text { yes } \\
\text { yes }\end{array}$ & $\begin{array}{l}\text { yes } \\
\text { yes }\end{array}$ & $\begin{array}{l}\text { yes } \\
\text { yes }\end{array}$ & $\begin{array}{l}\text { yes } \\
\text { yes }\end{array}$ \\
\hline
\end{tabular}

Dependent variable: net wealth (columns 1, estimated by OLS and IV regressions), financial wealth (columns 2, estimated by OLS and IV regressions), housing wealth (columns 3, probability of owning real estate property estimated by Probit and IV Probit and net value of real estate property estimated by Tobit and IV Tobit), risky financial assets (columns 4 , probability of holding risky financial assets estimated by Probit and IV Probit, amount of risky financial assets estimated by Tobit and IV Tobit). Other control variables: age, gender, and income of the reference person, household composition (number of children, number of household members in employment), having received any substantial gifts or inheritances, having been credit constrained within the last three years, future income expectations and willingness to take financial risks.Countries: Belgium, Germany, France, Greece, Italy, Luxembourg and Portugal. Estimated coefficients (and standard errors) of the displacement effects of pension on savings for OLS, IV, Tobit, and IV Tobit regressions. Marginal effects (and standard errors) for Probit and IV Probit. Net wealth, financial wealth, net housing wealth, risky financial assets, pension wealth and income are in thousands of euro. Pension wealth is adjusted by Gale's $Q$ factor. Significant at $* * * 1 \%, * * 5 \%$ and $* 10 \%$. Number of observations: 10,129 
Table C.4. Country-specific mean net and financial wealth

\begin{tabular}{|c|c|c|c|c|}
\hline & \multicolumn{2}{|c|}{ Net Wealth } & \multicolumn{2}{|c|}{ Financial wealth } \\
\hline Country & $\begin{array}{c}\text { OLS } \\
\text { Marginal Ef. } \\
\text { (Std. Err.) }\end{array}$ & $\begin{array}{c}\text { IV } \\
\text { Marginal Ef. } \\
\text { (Std. Err.) }\end{array}$ & $\begin{array}{c}\text { OLS } \\
\text { Marginal Ef. } \\
\text { (Std. Err.) }\end{array}$ & $\begin{array}{c}\mathbf{I V} \\
\text { Marginal Ef. } \\
\text { (Std. Err.) }\end{array}$ \\
\hline Belgium & $\begin{array}{l}-0.466 \\
(0.879)\end{array}$ & $\begin{array}{l}-0.822 \\
(0.951)\end{array}$ & $\begin{array}{l}-0.274 \\
(0.312)\end{array}$ & $\begin{array}{l}-0.433 \\
(0.317)\end{array}$ \\
\hline Germany & $\begin{array}{l}-0.121 \\
(0.470)\end{array}$ & $\begin{array}{c}0.070 \\
(0.708)\end{array}$ & $\begin{array}{l}-0.357 \\
(0.591)\end{array}$ & $\begin{array}{l}-0.385 \\
(0.921)\end{array}$ \\
\hline France & $\begin{array}{l}0.710^{*} \\
(0.398)\end{array}$ & $\begin{array}{c}1.262 \\
(1.392)\end{array}$ & $\begin{array}{c}0.157 \\
(0.298)\end{array}$ & $\begin{array}{c}0.466 \\
(1.050)\end{array}$ \\
\hline Greece & $\begin{array}{c}0 ; 634 \\
(0.490)\end{array}$ & $\begin{array}{c}0.686 \\
(0.522)\end{array}$ & $\begin{array}{c}0.113 \\
(0.138)\end{array}$ & $\begin{array}{c}0.157 \\
(0.140)\end{array}$ \\
\hline Italy & $\begin{array}{l}-1.171 \\
(1.063)\end{array}$ & $\begin{array}{l}-0.523 \\
(0.650)\end{array}$ & $\begin{array}{l}-0.625 \\
(0.476)\end{array}$ & $\begin{array}{l}-0.372 \\
(0.280)\end{array}$ \\
\hline Luxembourg & $\begin{array}{l}-8.508 \\
(6.093)\end{array}$ & $\begin{array}{l}-7.186 \\
(5.978)\end{array}$ & $\begin{array}{l}-6.709 \\
(4.658)\end{array}$ & $\begin{array}{l}-5.982 \\
(4.536)\end{array}$ \\
\hline Portugal & $\begin{array}{c}0.076 \\
(0.447)\end{array}$ & $\begin{array}{c}0.013 \\
(3.500)\end{array}$ & $\begin{array}{c}0.195 \\
(0.180)\end{array}$ & $\begin{array}{c}0.743 \\
(1.448)\end{array}$ \\
\hline
\end{tabular}

Country-by country regressions. Dependent variable: housing wealth (probability of owning real estate property estimated by Probit and IV Probit and net value of real estate property estimated by Tobit and IV Tobit), risky financial assets (probability of holding risky financial assets estimated by Probit and IV Probit, amount of risky financial assets estimated by Tobit and IV Tobit).

Contrive inheritances, having being credit constrained within the last three years, future income expectations and willingness to take financial risks.

Estimated coefficients (and standard errors) for Tobit, and IV Tobit regressions. Marginal effects (and standard errors) for Probit and IV Probit. Housing wealth, risky financial assets, pension wealth and income are in thousands of euro. Pension wealth is adjusted by Gale's Q factor. Significant at ${ }^{* * *} 1 \%, * * 5 \%$ and ${ }^{*} 10 \%$. Number of individuals: Belgium $(523)$, Germany $(1,238)$, France $(3,555)$, Greece $(548)$, Italy $(1,700)$, Luxembourg (702) and Portugal $(1,863)$ 